Sheffield Hallam University

Centre for Regional Economic and Social Research

\title{
The uneven impact of welfare reform \\ The financial losses to places and people
}

Christina Beatty Steve Fothergill

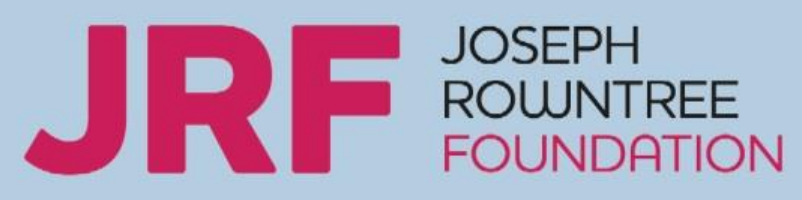





\title{
THE UNEVEN IMPACT OF WELFARE REFORM \\ The financial losses to places and people
}

\author{
Christina Beatty and Steve Fothergill \\ Centre for Regional Economic and Social Research \\ Sheffield Hallam University
}

March 2016

DOI: $10.3351 /$ cresr.2017.5563239352

The research on which the report is based was funded by Sheffield Hallam University, Joseph Rowntree Foundation and Oxfam.

The views expressed are those of the authors alone. 
The maps were produced using ( C Crown Copyright/database right (2015), an Ordnance Survey/EDINA supplied service. All data used in the calculations from the Office for National Statistics (ONS) and Nomis websites are subject to (C) Crown Copyright (2016). Data for Scotland from the National Records of Scotland (NRS) is subject to (c) Crown Copyright (2014). 


\section{Key points}

- The post-2015 welfare reforms will take almost £13bn a year from claimants by 2020-21.

- This brings the cumulative loss since 2010 to $£ 27 b n$ a year - equivalent to $£ 690$ a year for every adult of working age.

- The new reforms impact unevenly across the country. Older industrial areas, less prosperous seaside towns, some London boroughs and a number of other towns are hit hardest. By contrast, much of southern England a London escapes lightly.

- At the extremes, Blackburn and Blackpool in Lancashire each lose $£ 560$ per working age adult as a result of the post-2015 reforms, compared to $£ 150$ in Guildford in Surrey, $£ 140$ in Richmond upon Thames, and just $£ 130$ in Hart district in Hampshire.

- 15 of the 20 hardest-hit places have more than the GB average share of households with three or more dependent children. 12 of the 20 have a population of Asian ethnic origin exceeding 10 per cent.

- As a general rule, the more deprived the local authority the greater the financial loss.

- 83 per cent of the loss from the post-2015 reforms - £10.7bn a year by 2020-21 - can be expected to fall on families with dependent children. On average, couples with two or more dependent children lose $£ 1,450$ a year while lone parents with two or more lose $£ 1,750$ a year.

- The post-2015 reforms hit working-age tenants in the social rented sector particularly hard - on average they can expect to lose almost $£ 1,700$ a year, compared to £290 a year for working-age owner occupiers.

- Overall, £6.2bn a year of the financial loss arising from the post-2015 welfare reforms just under half - is estimated to fall on working-age social sector households.

- Parallel changes in tax, the minimum wage, social sector rents and childcare entitlement go some way to compensate but the winners and the losers are only sometimes the same people and it is unlikely that the full financial loss will be offset.

- A key effect of welfare reform is to widen the gap in prosperity between the best and worst local economies across the country. 


\section{THE UNEVEN IMPACT OF WELFARE REFORM The financial losses to places and people}

\section{Scope and purpose of the report}

Welfare reform has become a defining feature of contemporary UK government policy. The benefit changes introduced by the Coalition government from 2010 onwards were substantial and central to its social and economic strategy. Under its wholly Conservative successor, elected in May 2015, a second raft of welfare reform has already been initiated.

All but a couple of the welfare reforms apply to the whole country. The impact of the reforms, however, varies enormously from place to place, not least because benefit claimants are so unevenly spread across Britain. The impact also falls unevenly on different types of household.

It is to be expected that welfare reform will hit the poorest places hardest because they generally have large numbers of people reliant on benefits. On the other hand, the reforms extend well beyond just those who are out-of-work to include significant swathes of the employed population as well. So just how big is the impact on different places? Just how much harder are the reforms hitting the poorer parts of Britain than more prosperous areas? And what sorts of households face the biggest losses?

In a report published in $2013^{1}$ we quantified the local and regional impact of the welfare reforms that were underway at that time. The financial losses and the numbers affected were documented for each of Britain's 379 local authority areas ${ }^{2}$. The figures attracted wide attention and led to a series of follow-on reports looking in detail at the impact in Scotland ${ }^{3}$, Wales $^{4}$, Northern Ireland ${ }^{5}$ and in our local base, Sheffield ${ }^{6}$.

\footnotetext{
${ }^{1} \mathrm{C}$ Beatty and S Fothergill (2013) Hitting the Poorest Places Hardest: the local and regional impact of welfare reform, CRESR, Sheffield Hallam University

${ }^{2}$ Unitary authorities and district councils, excluding Isles of Scilly

${ }^{3}$ C Beatty and S Fothergill (2013) The Impact of Welfare Reform on Scotland. C Beatty and S Fothergill (2014) The Local Impact of Welfare Reform. C Beatty and S Fothergill (2015) The Cumulative Impact of Welfare Reform on Households in Scotland. C Beatty, S Fothergill and D Houston (2015) The Impact of Welfare Reform on the Scottish Labour Market. All published by the Scottish Parliament, Edinburgh.

${ }^{4} \mathrm{C}$ Beatty and S Fothergill (2014) The Impact of Welfare Reform on the Valleys, CRESR, Sheffield Hallam University

${ }^{5}$ C Beatty and S Fothergill (2013) The Impact of Welfare Reform on Northern Ireland, NICVA, Belfast

${ }^{6} \mathrm{C}$ Beatty and S Fothergill (2015) The Impact of Welfare Reform on Communities and Households in Sheffield, CRESR, Sheffield Hallam University
} 
This new report brings the story forward by including the welfare reforms announced since the May 2015 general election. It also updates all the figures for the pre-2015 reforms to take account of the actual outturn. This enables an assessment not only of the cumulative impact by the end of the present decade but also of how much has happened already and how much is still in the pipeline. In the report itself a limited number of statistics are presented on the impact of each of the individual benefit reforms. The full dataset, by benefit by authority, can be accessed at:

http://www.shu.ac.uk/research/cresr/sites/shu.ac.uk/files/welfare-reform-2016.xlsx

The report also includes wholly new figures on the impact of the post-2015 welfare reforms on different types of household and by housing tenure.

All the figures in the report are estimates but in every case they are deeply rooted in official statistics - for example in the Treasury's own estimates of the financial savings, the government's Impact Assessments, and benefit claimant data.

Welfare reform is a contentious issue and in documenting the impacts the report does not attempt to comment on the merits of each of the reforms. However, it is important that the impact on different places is fully exposed because this is a key dimension that is too often overlooked. The impact on different places is one of the yardsticks by which the reforms should be judged.

\section{The welfare reforms}

The figures in the report cover all the major welfare reforms implemented since 2010. Taking the pre-2015 reforms first, these are:

\section{Housing Benefit - Local Housing Allowance}

Changes to the rules governing assistance with the cost of housing for low-income households in the private rented sector. The new rules apply to rent levels, 'excess' payments, property size, age limits for sole occupancy and indexation for inflation.

\section{Housing Benefit - Under-occupation in the social rented sector}

New rules governing the size of properties for which payments are made to working age claimants (widely known, and referred to in the report, as the 'bedroom tax')

\section{Non-dependant deductions}

Increases in the deductions from Housing Benefit, Council Tax Support and other income-based benefits to reflect the contribution that non-dependant household members are expected to make towards the household's housing costs

\section{Benefit cap}

New ceiling on total payments per household, applying to the sum of a wide range of benefits for working age claimants

\section{Council Tax Support}

Reductions in entitlement of working age claimants arising from 10 per cent reduction in total payments to local authorities 


\section{Personal Independence Payment}

Replacement of Disability Living Allowance by PIP for working age claimants, including more stringent and frequent medical tests, as the basis for financial support to help offset the additional costs faced by individuals with disabilities

\section{Employment and Support Allowance}

Replacement of Incapacity Benefit and related benefits by ESA, with more stringent medical tests, greater conditionality and time-limiting of non-means tested entitlement for claimants in the Work-Related Activity Group

\section{Child Benefit}

Three-year freeze, and withdrawal of benefit from households including a higher earner

\section{Tax Credits}

Reductions in payment rates and eligibility for Child Tax Credit and Working Tax Credit, paid to lower and middle income households

\section{1 per cent up-rating}

Limit in annual up-rating of value of most working age benefits

A fuller description of each of these reforms, including the timing of implementation, is contained in the appendix to the report.

The majority of these welfare reforms were initiated by the Coalition government in Westminster but the introduction of ESA was a Labour measure that pre-dated 2010 and only took full effect later, whereas the time-limiting of non-means tested ESA entitlement was a Coalition innovation. The full impact of both the introduction and time-limiting of ESA is included here to provide a comprehensive view of the impact of the reforms implemented from 2010 onwards.

By March 2016 nearly all these reforms had come into full effect. The important exception is the changeover from DLA to PIP, which is not expected to be completed until March $2018^{7}$. In quantifying the impact of welfare reform over the next five years, a substantial proportion of the impact of the introduction of PIP therefore has to be included alongside more recently announced measures.

The new welfare reforms, announced by the Chancellor in July and November 2015, are:

\section{Universal Credit tapers and thresholds}

Reduction in the level of earnings and increase in the rate at which Universal Credit awards are withdrawn. This reform was originally to have applied to Tax Credits as well but will now only apply to Universal Credit, which is gradually replacing Tax Credits.

\footnotetext{
${ }^{7}$ HM Treasury, Budget 2013
} 


\title{
Tax Credits
}

Reductions in payments and thresholds, notably the removal for new claims of the 'family' element and a limit on the 'child' element to two children for children born after March 2017

\section{Mortgage interest support}

Change from welfare payment to a loan

\author{
'Pay to stay' \\ New requirement for higher-income tenants in the social rented sector in England to \\ pay market rents, mandatory in local authority housing and voluntary for housing \\ associations
}

\section{LHA cap in the social rented sector}

Housing Benefit in the social sector limited to the equivalent local private sector rate

\section{Housing Benefit: 18-21 year olds}

End of automatic entitlement for out-of-work 18-21 year olds

\section{Employment and Support Allowance}

Reduction in payment to JSA rate for new claimants in the Work-Related Activity Group

\section{Benefit cap}

Lower ceiling per household - £23,000 a year in London, £20,000 elsewhere applying to total of wide range of working age benefits

\section{Benefit freeze}

Four-year freeze in the value of most working-age benefits

Again, a fuller description of each of these new reforms, including the timing of implementation, is contained in the appendix.

An astute observer will note the omission of the introduction of Universal Credit, which is scheduled to replace just about all means-tested working age benefits and is administratively the most ambitious reform of all. However, the introduction of Universal Credit differs from the other reforms. Putting aside the revised tapers and thresholds (whose impact is included here in full) the introduction of Universal Credit has by itself never been expected to lead directly to a reduction in spending. Universal Credit is best understood as a repackaging of existing benefits that for the first time introduces a consistent withdrawal rate, with the rules governing eligibility carried over from the existing benefits it replaces. Indeed, in the shortrun transitional relief increases spending.

Ministers' hope is that Universal Credit will reduce welfare spending by always making work financially worthwhile and raising employment. However, the new tapers and thresholds mean that in practice, at the level of individuals and households, the losers from the transition to Universal Credit will now outnumber the winners. 
A further omission is the reduction in social sector rents (by 1 per cent a year in England, for four years from 2016-17). The Treasury estimates that this will save $£ 1,445 \mathrm{~m}$ a year by 2020-21 but the full burden of the financial loss falls on social landlords not tenants. The other welfare reforms documented here all impose losses on claimants. A minority of tenants who do not claim Housing Benefit will actually benefit financially from this measure (see discussion towards the end of the report) but the loss of rental income to social landlords may lead to a reduction in services and the volume of new building.

The list also omits the impact of benefit sanctions. What needs to be remembered here is that the power to impose benefit sanctions is not new - it has been a feature of the benefit system since its inception. What has happened since 2010 is that sanctions have been more widely applied, especially to those claiming Jobseeker's Allowance, though the numbers and the rate do now appear to have peaked ${ }^{8}$. The financial savings to the Treasury, though not negligible, are likely to be smaller than those arising from all but the most modest of the welfare reforms covered here ${ }^{9}$.

\section{Measuring the local and regional impacts}

The data sources and methods underpinning the local and regional estimates are set out in full in the appendix.

The government does not produce estimates of the local impact of the reforms. It does however publish a range of statistics that allow the local impact to be estimated. This information principally comprises:

- Treasury estimates of the anticipated saving arising from each element of the reforms, published in the Budget or in the government's Autumn Statement

- The Impact Assessments that government departments publish for most elements of the reforms

- Claimant numbers and expenditure, by local authority, published by DWP and HMRC

As far as possible, for each welfare reform the figures presented in the report take account of the overall financial saving to the Treasury, the distribution of claimants between local authorities, and the variation (if any) in the extent to which claimants in each authority are affected by the reforms ${ }^{10}$.

\footnotetext{
${ }^{8}$ See the quarterly briefings on the DWP sanctions statistics produced by David Webster of Glasgow University

${ }^{9}$ Other reforms that have been omitted are the reduction in the qualifying age of the youngest child exempting lone parents from looking for work, which does not reduce payment rates, and the changeover from RPI to CPI for benefits up-rating, introduced in 2011-12, which is a wider accounting reform affecting public sector pensions for example and has in practice been superseded by subsequent caps and freezes for most working-age benefits. New restrictions on Housing Benefit for claimants abroad for four weeks or more (saving: £10m a year by 2020-21) are also omitted.

${ }^{10}$ The estimates here make no allowance for the small share of the financial impact falling on Northern Ireland. The effect is to slightly overstate the impact on Great Britain, bearing in mind that Northern Ireland accounts for 3 per cent of the UK population.
} 
For all the pre-2015 reforms, the financial savings have been up-dated. This is sometimes because the Treasury itself has subsequently revised its estimates but in other cases it is because the outturn has proved different from what was originally anticipated. Lower inflation, for example, reduced the savings from the uprating of benefits by just 1 per cent, and the reforms to incapacity benefits (Employment and Support Allowance) failed to deliver anything like the financial savings that were expected.

In comparing the impact on different places, the report looks in particular at the financial loss per adult of working age ${ }^{11}$. This is the best measure of the intensity of the hit and takes account of the number of claimants in each locality. This is different to the financial loss facing each affected individual or household ${ }^{12}$. A focus on adults of working age (16-64) is appropriate because the welfare reforms impact almost exclusively on this group. By contrast, benefit claimants of pensionable age are largely unaffected ${ }^{13}$.

In estimating the impact of the welfare reforms the report holds all other factors constant. What this means in practice is that it makes no assumptions about the growth of the economy or about future levels of employment and unemployment. It also makes no assumptions about changes in claimant behaviour other than those already built in to the Treasury's estimates of the financial saving. So the figures in this report do not assume that loss of income from benefits will wholly or in part be replaced by additional income from employment.

Nevertheless, it must be emphasised that estimation of the impacts is not a precise science. Even the Treasury itself has from time to time had to revise its expectations, or indeed simply got it wrong. The figures here are all based on published estimates, official statistics and an informed appraisal of how each of the reforms can be expected to play out in different parts of the country.

\section{The overall national impact}

\section{Impact up to March 2016}

Table 1 shows the financial loss arising from each of the pre-2015 welfare reform across Great Britain as a whole. The first column shows the loss originally anticipated. These are Treasury figures, with modest adjustments where appropriate ${ }^{14}$. The second column shows the estimated annual loss to claimants by March 2016. These are revised Treasury estimates, adjusted as appropriate in the light of outturn data ${ }^{15}$.

\footnotetext{
${ }^{11}$ ONS mid-year population estimates 2014

${ }^{12}$ See Table 2

${ }^{13}$ The main exceptions are small numbers in the private rented sector affected by the reforms to Housing Benefit, adults of pensionable age who receive Child Benefit, those in receipt of mortgage interest support, and tenants affected by the new LHA cap on Housing Benefit in the social rented sector. The modest impact on pensioner households is documented in Table 10.

${ }^{14}$ These are the figures published in C Beatty and S Fothergill (2013) Hitting the Poorest Places Hardest op. cit., except for PIP which is the forecast for 2015-16 from Budget 2011.

${ }^{15}$ For reforms coming to full fruition by March 2015 the figures are the estimated losses in 2014-15 rather than 2015-16.
} 


\begin{tabular}{lcc}
\hline & $\begin{array}{c}\text { Initial } \\
\text { forecast } \\
\text { Em p.a. }\end{array}$ & $\begin{array}{c}\text { Estimated } \\
\text { outturn } \\
\text { Em p.a. }\end{array}$ \\
\hline Tax Credits & 3,660 & 4,210 \\
Child Benefit & 2,845 & 3,030 \\
1 per cent uprating & 3,430 & 2,700 \\
Housing Benefit: LHA & 1,645 & 1,670 \\
Personal Independence Payments & $1,450^{*}$ & 1,190 \\
Employment and Support Allowance & 4,350 & 650 \\
Council Tax Support & 340 & 370 \\
Housing Benefit: 'bedroom tax' & 490 & 360 \\
Non-dependant deductions & 340 & 210 \\
Benefit cap & 270 & 100 \\
\hline Total & $\mathbf{1 8 , 8 2 0}$ & $\mathbf{1 4 , 4 9 0}$ \\
\hline
\end{tabular}

*By 2015-16

Source: HM Treasury and Sheffield Hallam estimates based on official data

There are important differences between what was originally anticipated and what by March 2016 had proved to be the outturn. Overall, the financial loss to claimants has been £4.3bn a year less than forecast. The Treasury's revised figures ${ }^{16}$ suggest a further loss, still in the pipeline, of $£ 1,680 \mathrm{~m}$ a year by March 2018 from the changeover to Personal Independence Payments, taking the total loss arising from PIP far above the first estimate in Budget 2010 of $£ 1,500 \mathrm{~m}$ a year. Additionally, in Scotland and Wales and a number of English local authorities the reduction in Council Tax Support has not been passed on to claimants, and in Scotland the impact of the 'bedroom tax' on claimants has been averted as well. Even so, this still leaves the overall saving to the Treasury from all the pre-2015 reforms some $£ 2.5 \mathrm{bn}$ a year short of the original anticipated figure.

The reduction in spending on incapacity benefits - these days Employment and Support Allowance - accounts for by far the largest shortfall. Three factors are at the root of this. First, the new medical test (the Work Capability Assessment) has reduced incapacity numbers by far less than was anticipated, in part because under political pressure the test itself has undergone successive revisions. The headline number of incapacity claimants is only down by around 100,000 (to $2.5 \mathrm{~m}$ ), though it could be argued that without the new medical test the numbers would have been higher in the wake of recession. Second, following the medical test a much smaller proportion of ESA claimants have been placed in the Work-Related Activity Group than was originally expected. Again, this is probably attributable in part to revisions to the Work Capability Assessment. And third, as a result of the smaller than anticipated numbers in the Work-Related Activity Group, the financial savings to the Treasury arising from the time-limiting of non-means tested entitlement have been much less than was expected.

${ }^{16}$ HM Treasury, Budget 2013 
Table 2 shows the additional financial losses to claimants that can be expected by 2020-21. These arise principally from the new round of welfare reforms, announced in the Summer Budget and Spending Review in 2015, but also include the impacts of the changeover to PIP that in March 2016 were still in the pipeline. The financial losses shown here in the first column are all the Treasury's own estimates.

Table 2: Estimated additional financial loss arising from welfare reform by 2020-21

\begin{tabular}{|c|c|c|c|}
\hline & $\begin{array}{c}\text { Estimated } \\
\text { loss } \\
\text { Em p.a. }\end{array}$ & $\begin{array}{c}\text { Number of } \\
\text { households or } \\
\text { individuals } \\
\text { adversely affected }\end{array}$ & $\begin{array}{l}\text { Average loss per } \\
\text { affected } \\
\text { h'hold/individual } \\
\text { \& p.a. }\end{array}$ \\
\hline Benefit freeze & 4,010 & $7,900,000$ & 500 \\
\hline Universal Credit tapers \& thresholds & 3,220 & $3,000,000$ & 1,050 \\
\hline Tax Credits & 2,115 & $2,000,000$ & 1,050 \\
\hline Personal Independence Payments ${ }^{(1)}$ & 1,680 & 650,000 & 2,600 \\
\hline Employment and Support Allowance & 640 & 500,000 & 1,300 \\
\hline Benefit cap & 495 & 210,000 & 2,350 \\
\hline Mortgage interest support & 255 & 170,000 & 1,500 \\
\hline 'Pay to stay' & 240 & 130,000 & 1,850 \\
\hline LHA cap in social rented sector & 225 & 300,000 & 750 \\
\hline HB: 18-21 year olds & 40 & 15,000 & 2,600 \\
\hline Total & 12,920 & n.a. & n.a. \\
\hline
\end{tabular}

\footnotetext{
(1) Additional post-2015-16 impact of pre-2015 reform

(2) Individuals for PIP, ESA and 18-21s; households for all other benefits

Sources: HM Treasury, Impact Assessments and Sheffield Hallam estimates based on official data
}

By 2020-21, another $£ 12.9 \mathrm{bn}$ a year is expected to be taken from claimants - only a little less than the $£ 14.5 \mathrm{bn}$ a year lost by March 2016. In financial terms, the pace of welfare reform is set to slacken very little.

By early 2021, claimants are therefore expected to have lost a cumulative total of more than $£ 27 \mathrm{bn}$ a year as a result of the welfare reforms implemented since 2010. This is rather more than one pound in every four previously paid to working-age benefit claimants and equivalent to $£ 690$ a year for every adult of working age (claiming benefits or not) across the whole of Britain.

In the coming period the four-year freeze in the value of most working age benefits is expected to deliver the biggest savings to the Treasury - and the largest loss to claimants but the final amount will be sensitive to the rate of inflation: the higher inflation, the larger the loss to claimants. The impact of the freeze is spread relatively thinly across a very large number of households. 
The changes to the tapers and thresholds for the withdrawal of Universal Credit are also set to result in substantial losses but for fewer households, so the individual losses will be greater. The government had originally intended to apply these changes to Tax Credits as well, from April 2016, but reversed this decision in the 2015 Spending Review in response to the House of Lords refusal to vote the measure through. The plan has always been to integrate Tax Credits into Universal Credit so the effect has been to delay rather than avert the impact. Transitional relief is included in Universal Credit for those who have no change in circumstances but by 2021 the vast majority of claimants will be no better off than if the changes had been applied immediately to Tax Credits.

Among the other reforms, it is worth noting that the biggest financial losses attributable to the changeover to Personal Independence Payments are still to come ${ }^{17}$. The losses arising from the introduction of 'pay to stay' are exclusively those affecting local authority tenants, for whom the change is mandatory, and will be larger if housing associations use their discretionary power to follow suit.

The financial losses arising from the new, lower benefit cap are also expected to be much higher than from the cap that was introduced in 2013. The Treasury's estimate is that by 2020-21 the total losses from the new cap will be roughly five times higher than the outturn for the pre-2016 benefit cap. A loss of this magnitude is consistent with a ten-fold increase in the number of households subject to the cap. This represents a step-change in the role of the benefit cap in the welfare system.

The figures here and elsewhere in the report on the number of households or individuals affected are all a 'snapshot' at a single point in time. Over time, as people move on or off benefit - there is always turnover - the numbers who at some point feel the financial impact of the reforms will be substantially larger. Also, it is worth remembering that the numbers undergoing reassessment for PIP, for example, are much larger than those who eventually lose out financially. Only a proportion are 'adversely affected' in the sense that they lose money but for the remainder the process of reassessment is still likely to be a source of stress and anxiety.

Table 3 shows the scheduling of the financial losses, again using the Treasury's own figures. The scale of the anticipated loss rises steadily over the coming five years, with particularly hefty increases in years two and three.

In the period to March 2018 the biggest loss to claimants is anticipated to arise from the changeover to Personal Independence Payments - a pre-2015 reform rolling forward into the second half of the decade. Thereafter, some of the other reforms, notably the benefit freeze, reductions in Tax Credits and the new Universal Credit tapers and thresholds are expected to take effect in a big way. None of the housing-related reforms (the bottom four on the list in Table 3) are expected to deliver savings to the Treasury until 2017 and in some cases not until 2018.

\footnotetext{
${ }^{17}$ Until the autumn of 2015, PIP applied only to new claims, expiring time-limited claims and changes of circumstance. The reassessment of on-going DLA claims has now started.
} 


\begin{tabular}{lrrrrr} 
& $\mathbf{2 0 1 6 - 1 7}$ & $\mathbf{2 0 1 7 - 1 8}$ & $\mathbf{2 0 1 8 - 1 9}$ & $\mathbf{2 0 1 9 - 2 0}$ & $\mathbf{2 0 2 0 - 2 1}$ \\
\hline Benefit freeze & 90 & 940 & 2,325 & 3,885 & 4,010 \\
UC tapers \& thresholds & 970 & 1,220 & 2,045 & 2,745 & 3,220 \\
Tax Credits & 285 & 1,020 & 1,640 & 1,980 & 2,115 \\
PIP & 810 & 1,680 & 1,680 & 1,680 & 1,680 \\
ESA & 0 & 55 & 225 & 445 & 640 \\
Benefit Cap & 100 & 310 & 360 & 405 & 495 \\
Mortgage interest support & -30 & -35 & 270 & 255 & 255 \\
'Pay to stay' & 0 & 365 & 185 & 245 & 240 \\
LHA cap in social sector & 0 & 0 & 120 & 170 & 225 \\
HB: 18-21 year olds & 0 & 25 & 35 & 35 & 40 \\
\hline Total & $\mathbf{2 , 2 2 5}$ & $\mathbf{5 , 5 8 0}$ & $\mathbf{8 , 8 8 5}$ & $\mathbf{1 1 , 8 4 5}$ & $\mathbf{1 2 , 9 2 0}$ \\
\% of $\mathbf{2 0 2 0 - 2 1}$ total & $\mathbf{1 7}$ & $\mathbf{4 3}$ & $\mathbf{6 9}$ & $\mathbf{9 2}$ & $\mathbf{1 0 0}$ \\
\hline
\end{tabular}

Source: HM Treasury

\section{Impact on local areas by March 2016}

Figure 1 shows the estimated financial loss by local authority up to March 2016. All these losses result from the pre-2015 welfare reforms. The measure used here is the loss per adult of working age so the data measures the intensity of the financial impact in each area.

The impact by March 2016 presents a seemingly complex picture but there are clear patterns. Three types of area have been hit hardest:

- The older industrial areas of England, Scotland and Wales. These include substantial parts of North West and North East England, the South Wales Valleys and the Glasgow area in Scotland. Older industrial areas tend to have high numbers on out-of-work benefits and on low wages, which triggers Tax Credits and Housing Benefit as income top-ups.

- A number of less prosperous seaside towns. These too often have high numbers on out-of-work benefits and on low wages, and a large private-rented housing market which Housing Benefit reforms have hit hard

- Some London boroughs. Some of these are also relatively deprived, but high housing costs have inflated the losses arising from the Housing Benefit reforms in the private-rented sector. 
Figure 1: Estimated loss arising from welfare reform by March 2016, by district

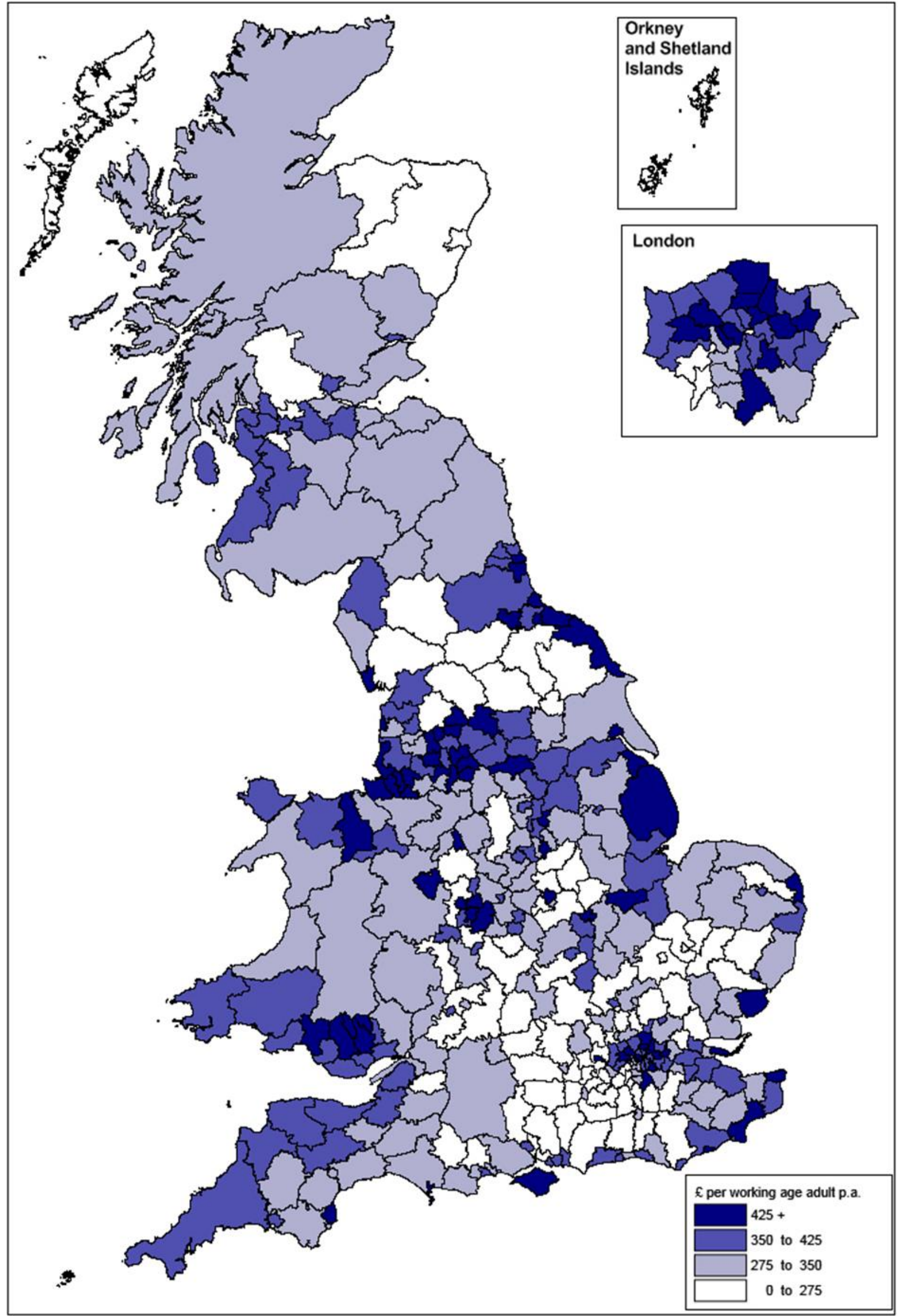

Source: Sheffield Hallam estimates based on official data 


\begin{tabular}{lccc}
\hline & $\begin{array}{c}\text { Loss per } \\
\text { working } \\
\text { age adult } \\
\text { E p.a. }\end{array}$ & & $\begin{array}{c}\text { Loss per } \\
\text { working } \\
\text { age adult } \\
\text { E p.a. }\end{array}$ \\
\hline TOP 10 DISTRICTS & & BOTTOM 10 DISTRICTS & \\
Blackpool & 720 & South Oxfordshire & 220 \\
Westminster & 680 & Winchester & 220 \\
Knowsley & 560 & South Northamptonshire & 220 \\
Brent & 550 & Wokingham & 210 \\
Middlesbrough & 550 & Aberdeenshire & 210 \\
Hastings & 540 & Guildford & 210 \\
Barking and Dagenham & 540 & Hart & 210 \\
Torbay & 530 & Aberdeen & 210 \\
Enfield & 530 & Shetland & 200 \\
Hartlepool & 520 & Cambridge & 190 \\
\hline
\end{tabular}

Source: Sheffield Hallam estimates based on official data

At the other end of the spectrum, a substantial part of southern England outside London has been much less acutely affected by the pre-2015 welfare reforms. A number of rural areas in northern England, including most of North Yorkshire and parts of Cumbria, plus the Aberdeen area in Scotland, also escaped relatively lightly.

Table 4 lists the local authorities with the largest and smallest financial losses ${ }^{18}$, per adult of working age, up to March 2016. At the top of the list comes Blackpool, the famous seaside resort in North West England, where the average loss per working age adult is estimated to be $£ 720$ a year. Blackpool tops the list for a number of reasons. It has a high proportion of adults of working age out-of-work on benefits, including one of the highest incapacity claimant rates in the country. It also has a high proportion of households living in the private-rented sector, who have been badly exposed to the reductions in the Local Housing Allowance element of Housing Benefit, and low wages in the local economy have inflated the numbers hit by the reductions in Tax Credits. Westminster, at number two on the list, has been hard hit because extremely high rents mean that, more than anywhere else in Britain, the Housing Benefit reforms and the Benefit Cap have led to exceptionally large financial losses.

Nevertheless, in all the worst affected local authorities the financial losses by March 2016 are less than had been anticipated ${ }^{19}$, often by $£ 150-200$ per adult of working age. In particular this is because the reduction in ESA numbers and spending has been far less than expected. The worst affected districts have nevertheless still experienced losses that are typically two-and-a-half to three times higher, per adult of working age, than the least affected districts.

\footnotetext{
${ }^{18}$ Excluding City of London (the financial district) which has a very small population

${ }^{19}$ See C Beatty and S Fothergill (2013) Hitting the Poorest Places Hardest, op. cit.
} 


\section{Anticipated local impact 2016-21}

Figure 2 shows the estimated financial loss, by local authority, anticipated to arise by 202021 from the post-2015 welfare reforms. Again, the measure used here is the loss per adult of working age so the data measures the intensity of the financial impact in each area. Table 5 lists the 50 local authority districts anticipated to experience the largest financial loss and contrasts this with the 20 least affected ${ }^{20}$.

As in the period up to 2016 , older industrial areas figure prominently among the hardest-hit places. So do a number of less prosperous seaside towns and London boroughs. But the new round of welfare reform also hits hard in a number of places such as Leicester, Peterborough and Luton that have generally robust local economies with relatively low levels of unemployment.

What the local impact of the post-2015 welfare reforms illustrates is that the new benefit cuts are not confined just to those who are out of work. Tax Credit changes and Universal Credit tapers and thresholds mainly impact on those in work on low and middle incomes. The introduction of 'pay to stay' in social housing impacts almost exclusively on those in work. And because some of the new reforms impact on large families - the Tax Credit changes and the lower Benefit Cap for example - the places that have above-average numbers of large families are amongst the worst-hit this time round.

Blackburn, at the top of the list of hard-hit areas, illustrates this point. Blackburn is an older industrial area with a relatively high out-of-work claimant rate but what pushes it to the top is that it is estimated to be the worst-hit place in Britain by the reductions to Tax Credits and the second-worst hit by the new Universal Credit tapers and thresholds. This reflects low wages in employment and Blackburn's high proportion of households with three or more dependent children -8.4 per cent compared to the GB average of 4.6 per cent ${ }^{21}$. Blackburn is also estimated to be the fourth worst-hit place by the revised Benefit Cap, again a reflection in part of family size.

Of the 20 hardest-hit local authorities, 15 have more than the GB average share of households with three or more dependent children ${ }^{22}$. In 12 of the hardest hit 20 - often the same places - the share of the population of Asian ethnic origin also exceeds 10 per cent ${ }^{23}$.

What the estimates of the local impact of the post-2015 reforms also illustrate is that a different package of reform generates a different geography. Nowhere illustrates this better than the London borough of Westminster, estimated to have had the second-highest financial losses (per adult of working age) in Britain up to March 2016, primarily as a result of the reforms to Housing Benefit in the private rented sector. Looking at the post-2015 reforms, Westminster ranks 290 (out of 378 ) in terms of the estimated financial loss.

\footnotetext{
${ }^{20}$ Excluding City of London

${ }^{21}$ Source: 2011 Census of Population

${ }^{22}$ The exceptions are Blackpool, Knowsley, Thanet, Hastings, Merthyr Tydfil and Hull

${ }^{23}$ The exceptions are Blackpool, Knowsley, Middlesbrough, Thanet, Hastings, Merthyr Tydfil, Hull and Stoke-on Trent. Source: 2011 Census of Population.
} 
Figure 2: Anticipated loss by 2020-21 arising from post-2015 welfare reforms, by district

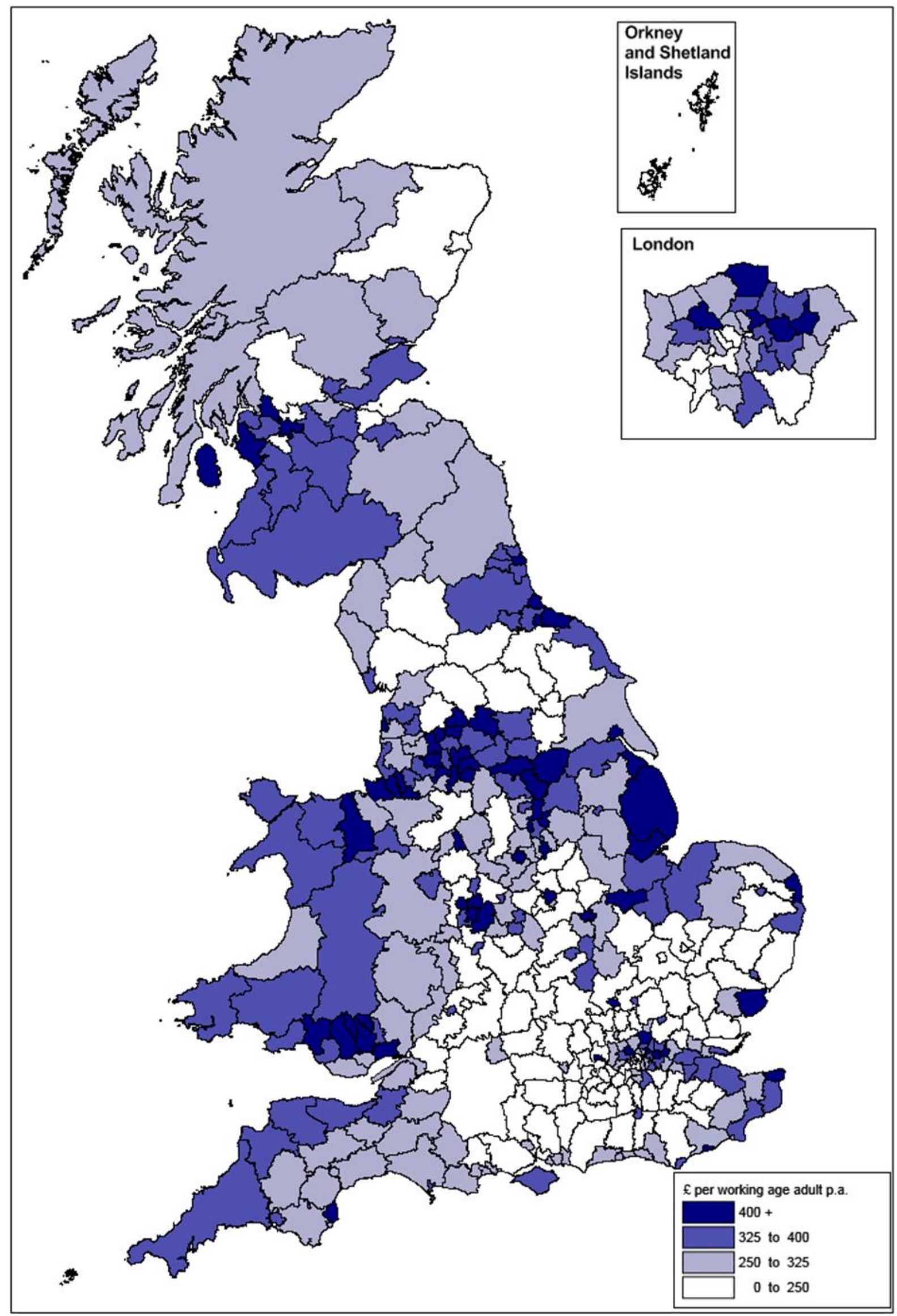

Source: Sheffield Hallam estimates based on official data 


\section{Loss per \\ working \\ age adult \\ E p.a.}

Loss per

working

age adult

E p.a.

\section{TOP 50 DISTRICTS}

1. Blackburn with Darwen

2. Blackpool

3. Barking and Dagenham

4. Bradford

5. Knowsley

6. Sandwell

7. Oldham

8. Birmingham

9. Leicester

10. Middlesbrough

11. Burnley

12. Thanet

13. Hyndburn

14. Pendle

15. Rochdale

16. Hull

17. Merthyr Tydfil

18. Stoke-on-Trent

19. Hastings

20. Newham

21. Peterborough

22. Enfield

23. Torbay

24. Wolverhampton

25. Great Yarmouth

26. Luton

27. Blaenau Gwent

28. Bolton

29. Walsall

30. Neath Port Talbot

31. Corby

32. Hartlepool

33. Manchester

34. Mansfield

35. Boston

36. Nottingham

37. Caerphilly

38. Glasgow

39. Denbighshire (cont)

40. South Tyneside 420

41. Tameside 420

42. Tendring 420

43. Barnsley 420

44. Rhondda Cynon Taf 420

45. Liverpool 420

46. Doncaster 410

47. Hackney 410

48. Salford 410

49. West Dunbartonshire 410

50. North East Lincolnshire 410

BOTTOM 20 DISTRICTS

359. Mid Sussex

170

170

170

170

170

170

170

160

160

160

160

150

150

150

150

150

150

140

140

130 
Again, much of southern England outside London escapes lightest. With the notable exception of the Shetland Islands, all the 20 districts least affected by the post-2015 welfare reforms are within a hundred mile radius of London.

Table 6 summarises the impact by region. The North East and North West are hit hardest, and Wales, the West Midlands and Yorkshire are not far behind. The South West, East and South East are the least severely affected.

Table 6: Anticipated loss by 2020-21 arising from post-2015 welfare reforms, by region

\begin{tabular}{lcc}
\hline & $\begin{array}{c}\text { Estimated } \\
\text { loss } \\
\text { Em p.a. }\end{array}$ & $\begin{array}{c}\text { Loss per } \\
\text { working age adult } \\
\text { \& p.a. }\end{array}$ \\
\hline North West & 1,710 & 380 \\
North East & 620 & 380 \\
Wales & 720 & 370 \\
West Midlands & 1,310 & 370 \\
Yorkshire and the Humber & 1,230 & 360 \\
East Midlands & 970 & 330 \\
London & 1,870 & 320 \\
Scotland & 1,100 & 320 \\
South West & 980 & 290 \\
East & 1,040 & 280 \\
South East & 1,390 & 250 \\
\hline Great Britain & $\mathbf{1 2 , 9 2 0}$ & 320 \\
\hline
\end{tabular}

Source: Sheffield Hallam estimates based on official data

\section{The cumulative impact}

The new welfare reforms come on top of reforms that have been implemented since 2010 . Figure 3 shows the cumulative local impact by local authority across Britain. The data here is the estimated financial loss in 2020-21, per adult of working age, arising from all the pre and post-2015 reforms.

As the summation of the impacts in the two sub-periods, this map reinforces the point that it is older industrial areas, poorer seaside towns and a number of London boroughs, plus a handful of other towns, that are hit hardest while much of southern England around London escapes lightly. 
Figure 3: Anticipated loss by 2020-21 arising from all pre and post-2015 welfare reforms, by district

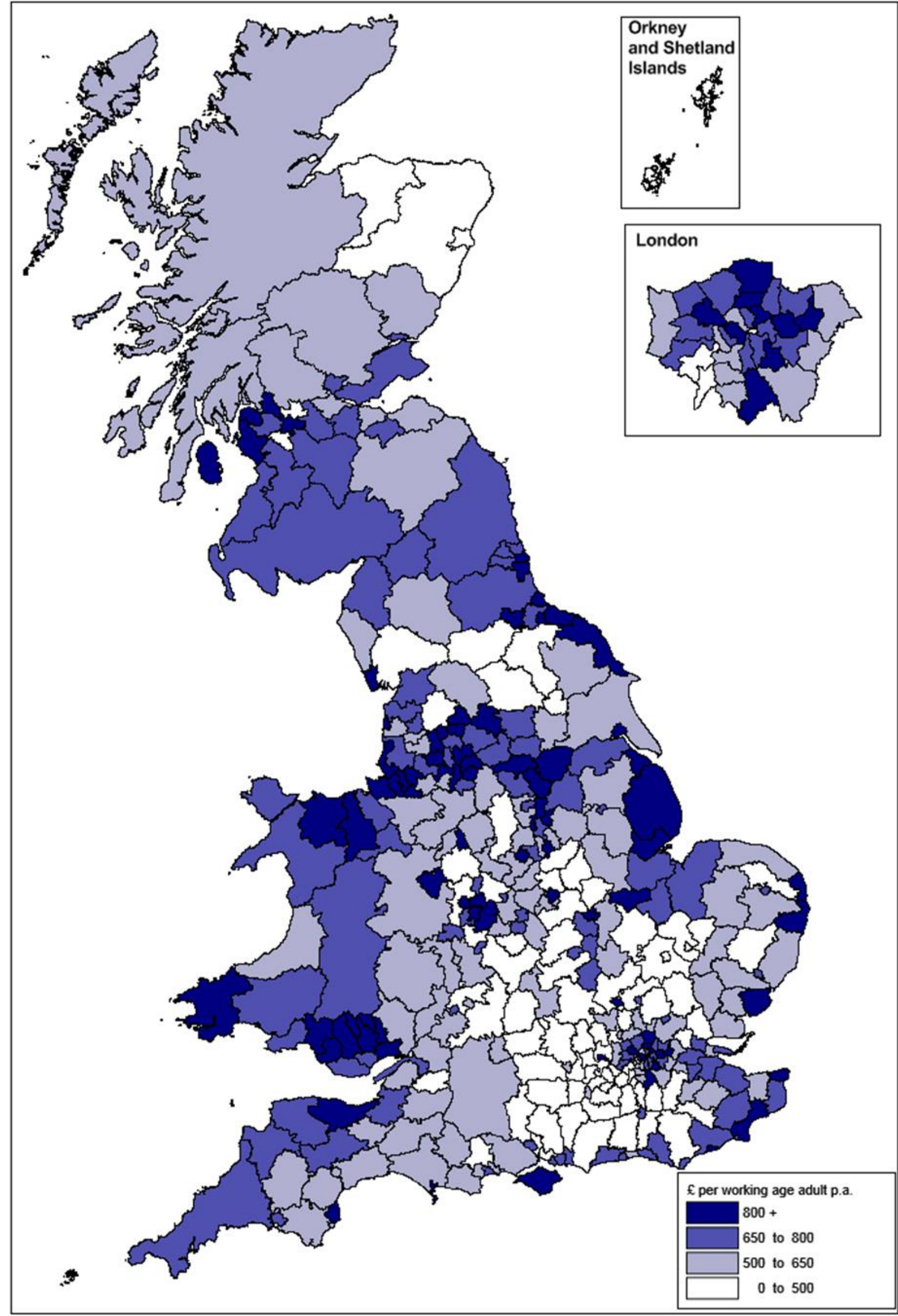

Source: Sheffield Hallam estimates based on official data 
Table 7: Anticipated loss by 2020-21 arising from all pre and post-2015 welfare reforms

$\begin{array}{cc}\text { Loss per } & \text { Loss per } \\ \text { working } & \text { working } \\ \text { age adult } & \text { age adult } \\ \text { £ p.a. } & \text { £ p.a. }\end{array}$

\begin{tabular}{lrll}
\hline TOP 10 DISTRICTS & \multicolumn{3}{c}{ BOTTOM 10 DISTRICTS } \\
Blackpool & 1,270 & Rutland & 390 \\
Knowsley & 1,070 & Mole Valley & 380 \\
Blackburn with Darwen & 1,070 & South Oxfordshire & 370 \\
Barking and Dagenham & 1,060 & South Northamptonshire & 370 \\
Middlesbrough & 1,040 & South Buckinghamshire & 370 \\
Hastings & 1,010 & Guildford & 360 \\
Thanet & 1,000 & Shetland & 360 \\
Burnley & 1,000 & Wokingham & 360 \\
Torbay & 990 & Cambridge & 350 \\
Hyndburn & 980 & Hart & 340 \\
\hline
\end{tabular}

Source: Sheffield Hallam estimates based on official data

Table 8: Anticipated loss by $\mathbf{2 0 2 0 - 2 1}$ arising from all pre and post-2015 welfare reforms, by region

\begin{tabular}{lcc}
\hline & $\begin{array}{c}\text { Estimated } \\
\text { loss } \\
\text { Em p.a. }\end{array}$ & $\begin{array}{c}\text { Loss per } \\
\text { working age adult } \\
\text { £ p.a. }\end{array}$ \\
\hline North West & 3,600 & 790 \\
North East & 1,300 & 790 \\
Wales & 1,450 & 770 \\
West Midlands & 2,650 & 750 \\
Yorkshire and the Humber & 2,550 & 750 \\
London & 4,250 & 730 \\
East Midlands & 2,000 & 680 \\
Scotland & 2,200 & 640 \\
South West & 2,100 & 630 \\
East & 2,200 & 600 \\
South East & 3,100 & 560 \\
\hline Great Britain & $\mathbf{2 7 , 4 0 0}$ & 690 \\
\hline
\end{tabular}

Source: Sheffield Hallam estimates based on official data 
Table 7 lists the local authorities with the largest and smallest estimated financial loss over the full period ${ }^{24}$. Two points are worth noting here. First, by 2020-21 the loss in a number of places is estimated to exceed $£ 1,000$ a year per adult of working age. Second, the districts with the largest losses are typically hit three times harder than those with the smallest losses.

Table 8 shows the losses over the full period by region. This underlines the point once again that southern England outside London is escaping lightest.

\section{The relationship to deprivation}

Figure 4 shows the relationship between the estimated financial loss from the post-2015 welfare reforms (per adult of working age) and the scale of deprivation in each local authority. The deprivation measure used here is the share of local neighbourhoods ${ }^{25}$ in the worst 20 per cent nationally. To overcome inconsistencies between the separate deprivation indices for the constituent countries of the UK, the deprivation figures here are taken from research that re-works the data to produce statistics for the UK as a whole ${ }^{26}$.

Figure 4: Relationship between deprivation and anticipated financial loss in $\mathbf{2 0 2 0 - 2 1}$ from post2016 welfare reforms, by local authority

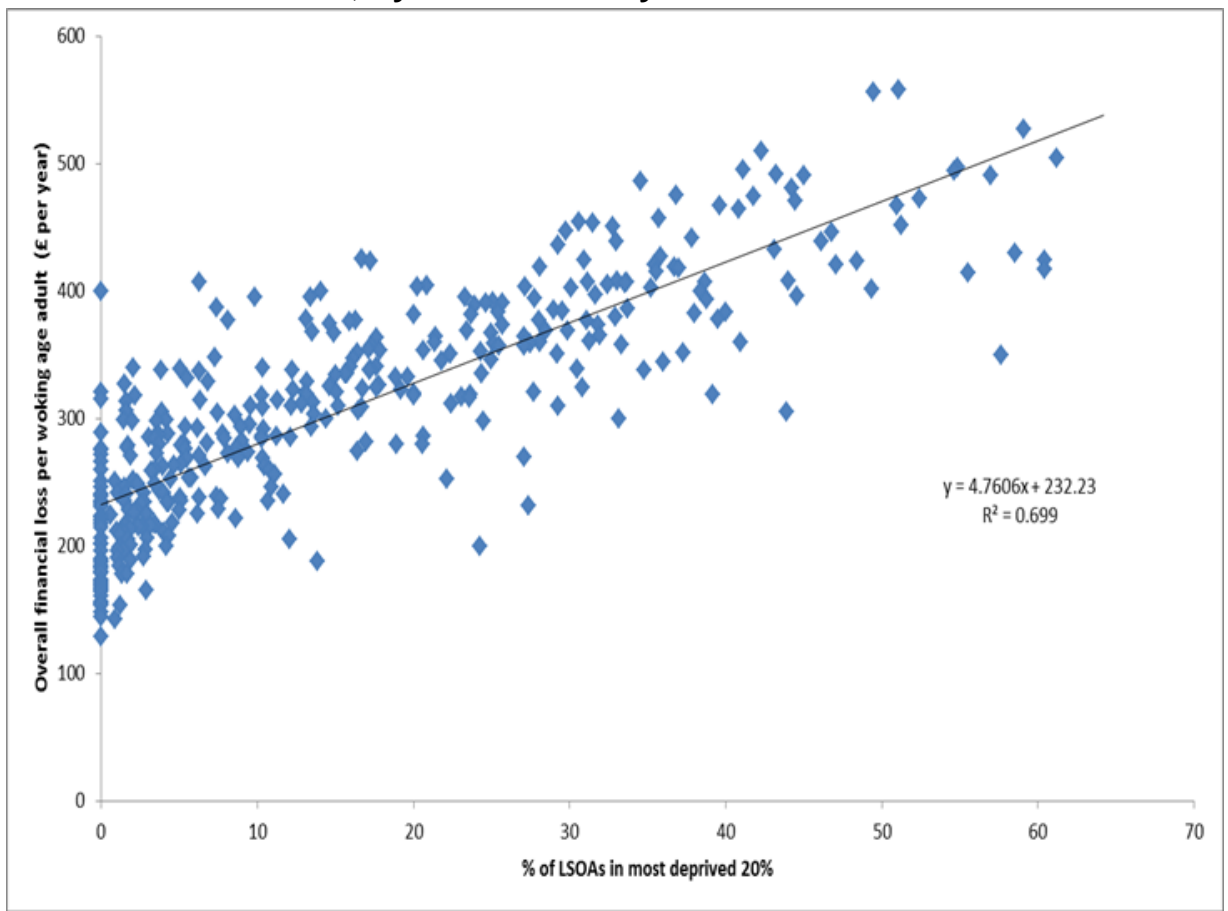

Sources: Sheffield Hallam estimates and University of Cambridge

\footnotetext{
${ }^{24}$ Excluding City of London

${ }^{25}$ Lower Super Output Areas in England and Wales, Datazones in Scotland.

${ }^{26}$ These particular statistics have been generated by Matthew Barclay and Rupert Payne of the University of Cambridge who have kindly made available their most up to date figures based on the most recent published Indices for England, Scotland, Wales and Northern Ireland. For details of their methods see R Payne and G Abel (2012) 'UK indices of multiple deprivation - a way to make comparisons across constituent countries easier', Health Statistics Quarterly, vol 53, pp 1-16.
} 
There is a clear and unambiguous relationship: as a general rule, the more deprived the local authority, the greater the financial hit. Overall, for every ten percentage point increase in the share of neighbourhoods in the most deprived 20 per cent, the scale of the financial loss arising from the welfare reforms rises by roughly $£ 48$ a year per adult of working age.

\section{The impact by household type}

Table 9 lists the types of individuals and households most likely to face a reduction in income as a result of each of the post-2015 reforms. A key point about these reforms, like their predecessors, is that they often impact simultaneously on the same individuals and

Table 9: Groups typically most affected by post-2015 welfare reforms

PERSONAL INDEPENDENCE PAYMENT (post-March 2016 impact)

- Existing Disability Living Allowance claimants undergoing reassessment

- Less severely disabled of working age, mostly older, mostly out-of-work

\section{UNIVERSAL CREDIT TAPERS AND THRESHOLDS}

- Low-income households in work

\section{TAX CREDITS (new reforms)}

- Low to middle income families, including households in work and out of work

- Larger families, especially those having a third or additional child

\section{MORTGAGE INTEREST SUPPORT}

- Long-term out-of-work households with a mortgage, including those on ESA

- Some retirees

\section{'PAY TO STAY'}

- Higher income social housing tenants in England, mostly in work, especially in areas with high market rents

\section{LHA CAP IN SOCIAL RENTED SECTOR}

- Out-of-work and low income social housing tenants, but not in all cases (depending on local rent levels and property type)

\section{HOUSING BENEFIT: 18-21 YEAR OLDS}

- Young unemployed not living with parents

\section{EMPLOYMENT AND SUPPORT ALLOWANCE (new reform)}

- Out-of-work, mainly older adults with less severe health problems or disabilities

- New claimants only

\section{BENEFIT CAP (extension)}

- Larger out-of-work families

- Out-of-work households in areas with high housing costs

\section{BENEFIT FREEZE}

- Everyone on the main working age benefits (JSA, ESA, IS, HB(LHA), UC, Tax Credits, Child Benefit) 
households. In-work households on low income, for example, may lose out through both the changes in Tax Credits and, at a later point, the new tapers and thresholds in Universal Credit, and the benefit freeze applies too. Similarly, an out-of-work individual with health problems or disabilities may face both a loss of income from PIP and a reduction in ESA.

Table 10 shows the average loss arising from the post-2015 welfare reforms for each of 15 different household types. The figures show the estimated loss in 2020-21 when this new round of reform has come to full fruition.

The financial losses in this table are based on the Treasury's estimated savings, information in the Impact Assessments, statistics on the proportion of each household type receiving each benefit and, where necessary, plausible assumptions about the likely impact of different elements of the reform package. The detailed methods are set out in the appendix.

It is important to underline that the figures are averages across the whole stock of households of each type, not just those hit by the welfare reforms. Thus the modest loss for couples with no children, for example, averages substantial losses for some households together with large numbers of other couples who are entirely unaffected by the welfare reforms.

Table 10: Anticipated loss in 2020-21 from post-2015 welfare reforms, by household type

\begin{tabular}{lcc}
\hline & $\begin{array}{c}\text { Number of } \\
\text { households of } \\
\text { each type, GB, } \\
\text { millions, 2011 }\end{array}$ & $\begin{array}{c}\text { Average } \\
\text { financial loss } \\
\text { £ p.a. }\end{array}$ \\
\hline Pensioner couple & 2.1 & 40 \\
Single pensioner & 3.2 & 40 \\
Couple - no children & 4.5 & 200 \\
Couple - one dependent child & 2.0 & 900 \\
Couple - two or more dependent children & 2.9 & 1,450 \\
Couple - all children non-dependent & 1.6 & 200 \\
Lone parent - one dependent child & 1.0 & 1,400 \\
Lone parent - two or more dependent children & 0.8 & 1,750 \\
Lone parent - all children non-dependent & 0.9 & 250 \\
Single person working age household & 4.7 & 250 \\
Other - with one dependent child & 0.3 & 1,130 \\
Other - with two or more dependent children & 0.3 & 1,360 \\
Other - all full-time students & 0.2 & 0 \\
Other - all aged 65+ & 0.1 & 50 \\
Other & 1.1 & 300 \\
\hline
\end{tabular}

Sources: Census of Population and Sheffield Hallam estimates based on official data 


\begin{tabular}{|c|c|c|c|c|c|c|c|c|c|c|c|}
\hline & PIP & $\begin{array}{c}\text { UC tapers } \\
\text { and } \\
\text { thresholds }\end{array}$ & $\begin{array}{c}\text { Tax } \\
\text { Credits }\end{array}$ & $\begin{array}{l}\text { Mortgage } \\
\text { Interest } \\
\text { Support }\end{array}$ & $\begin{array}{l}\text { 'Pay } \\
\text { to } \\
\text { stay' }\end{array}$ & $\begin{array}{l}\text { LHA } \\
\text { cap in } \\
\text { social } \\
\text { sector }\end{array}$ & $\begin{array}{l}\text { HB: } \\
18-21 \\
\text { year } \\
\text { olds }\end{array}$ & ESA & $\begin{array}{c}\text { Benefit } \\
\text { Cap }\end{array}$ & $\begin{array}{l}\text { Benefit } \\
\text { freeze }\end{array}$ & Total \\
\hline Pensioner couple & 0 & 20 & 0 & 45 & 0 & 15 & 0 & 0 & 0 & 10 & 80 \\
\hline Single pensioner & 0 & 0 & 0 & 70 & 0 & 20 & 0 & 0 & 0 & 40 & 130 \\
\hline Couple no children & 415 & 70 & 2 & 5 & 75 & 30 & 0 & 130 & 10 & 230 & 970 \\
\hline Couple 1 child & 115 & 550 & 200 & 35 & 25 & 15 & 0 & 50 & 50 & 800 & 1,830 \\
\hline Couple 2 or more children & 235 & 1,050 & 1,470 & 50 & 35 & 25 & 0 & 60 & 75 & 1,220 & 4,220 \\
\hline Couple all children non-dependent & 145 & 20 & 1 & 2 & 25 & 10 & 0 & 45 & 2 & 80 & 340 \\
\hline Lone parent 1 child & 95 & 620 & 110 & 15 & 5 & 25 & 0 & 40 & 130 & 430 & 1,470 \\
\hline Lone parent 2 or more children & 85 & 500 & 220 & 15 & 5 & 20 & 0 & 25 & 200 & 330 & 1,400 \\
\hline Lone Parent all children non-dependent & 75 & 10 & 0 & 1 & 15 & 5 & 0 & 35 & 2 & 80 & 230 \\
\hline Single person working age household & 375 & 70 & 0 & 5 & 5 & 30 & 20 & 190 & 10 & 420 & 1,130 \\
\hline Other - with one dependent child & 25 & 140 & 30 & 5 & 10 & 5 & 0 & 15 & 5 & 130 & 370 \\
\hline Other - with two or more dependent children & 25 & 160 & 80 & 5 & 10 & 5 & 0 & 15 & 5 & 130 & 440 \\
\hline Other- all full-time students & 0 & 0 & 0 & 0 & 0 & 0 & 0 & 0 & 0 & 0 & 0 \\
\hline Other - all aged $65+$ & 0 & 0 & 0 & 2 & 0 & 1 & 0 & 0 & 0 & 1 & 3 \\
\hline Other & 90 & 20 & 0 & 1 & 25 & 20 & 20 & 45 & 2 & 100 & 320 \\
\hline Total & 1,680 & 3,220 & 2,115 & 255 & 240 & 225 & 40 & 640 & 495 & 4,010 & 12,920 \\
\hline
\end{tabular}

Source: Sheffield Hallam estimates based on official data 
The striking feature is the uneven impact of the welfare reforms. Pensioner households are little affected - this was always built-in to the design of the reforms, which are targeted at the working age to encourage employment. At the other end of the spectrum, households with dependent children lose substantial sums - from an average of $£ 900$ a year for a couple with one dependent child through to $£ 1,750$ a year for a lone parent with two or more dependent children. Again, these are averages that will hide important differences between individual households, depending on their circumstances. Just as some households with dependent children will lose significantly less than these averages, others will lose substantially more, perhaps much more.

To understand why families with dependent children can be expected to lose large sums from the welfare reforms, Table 11 disaggregates the loss by household type into its component parts. This shows that it is the changes to Tax Credits, the new Universal Credit tapers and thresholds, and the benefit freeze that hit families with dependent children hardest. Lone parents with dependent children can also be expected to be hit hard by the new, lower Benefit Cap. By contrast, couples without dependent children, who are often a somewhat older group, can expect to lose most from the replacement of Disability Living Allowance by Personal Independence Payments, a pre-2015 reform that is still some way off full implementation.

In total, by $2020-21$ an estimated loss of $£ 10.7$ bn a year can be expected to fall on families with dependent children. This is 83 per cent of the overall financial loss arising from the post-2015 welfare reforms.

\section{The impact by housing tenure}

Table 12 divides the financial loss by housing tenure. The figures show the estimated annual loss in 2020-21 arising from the new round of reforms, including the post-March 2016 impact of the changeover to Personal Independence Payments. As with the estimates by household type, the losses in this table are based on the Treasury's estimated savings, information in the Impact Assessments, statistics on the proportion of each tenure group receiving each benefit and, where necessary, plausible assumptions about the likely impact of different element of the reform package. The detailed methods are set out in the appendix.

Table 12: Anticipated loss in 2020-21 arising from post-2015 welfare reforms, by tenure

\begin{tabular}{lccc}
\hline & $\begin{array}{c}\text { Number of } \\
\text { households, GB, } \\
\text { millions, 2011 }\end{array}$ & $\begin{array}{c}\text { Average loss per } \\
\text { household } \\
\mathbf{£} \text { p.a. }\end{array}$ & $\begin{array}{c}\text { Average loss } \\
\text { per working } \\
\text { age household } \\
\mathbf{E} \text { p.a. }\end{array}$ \\
\hline Social rented sector & 4.7 & 1,330 & 1,690 \\
Private rented sector & 4.5 & 710 & 730 \\
Owner occupied & 16.3 & 230 & 290 \\
\hline
\end{tabular}

Sources: Census of Population and Sheffield Hallam estimates based on official data 
The table provides two measures of the average loss per household in each sector - across all households, and per working age household ${ }^{27}$. Of these, the second is the more revealing because nearly all the financial loss from the welfare reforms falls on working age households, as Table 10 demonstrated earlier, and because pensioner households are unevenly spread across the three sectors.

The striking feature here is the estimated scale of the loss to working-age households in the social rented sector - on average, almost $£ 1,700$ a year, or more than five times as much as the average loss to working-age owner-occupiers. Once again it is important to emphasise that some households in the social rented sector will lose less than this average amount while others can be expected to lose considerably more.

Table 13 shows how much each of the post-2015 reforms contributes to the financial loss to working age households in the social rented sector. The introduction of 'pay to stay' and the Local Housing Allowance cap in the social rented sector and have attracted the attention of social landlords and tenants. However, across the post-2015 reforms as a whole, by 2020 21 the biggest sources of financial loss are likely to be the benefit freeze, the new Universal Credit tapers and thresholds, changes to tax credits and the on-going replacement of Disability Living Allowance by Personal Independence Payments. Some of these losses, such as those resulting from the benefit freeze, are spread thinly across large numbers of households; others have a bigger impact on a smaller proportion of social sector tenants.

Table 13: Anticipated loss in 2020-21 to working-age households in the social rented sector arising from post-2015 welfare reforms

\section{Em p.a.}

\begin{tabular}{lr}
\hline Benefit freeze & 2,250 \\
UC tapers and thresholds & 1,300 \\
Tax credits & 850 \\
Personal Independence Payments & 750 \\
Employment and Support Allowance & 310 \\
Benefit Cap & 280 \\
'Pay to stay' & 240 \\
LHA cap in social rented sector & 190 \\
HB: $18-21$ year olds & 20 \\
Mortgage interest support & 0 \\
\hline \multirow{2}{*}{ Total } & $\mathbf{6 , 2 0 0}$ \\
\hline
\end{tabular}

Source: Sheffield Hallam estimates based on official data

\footnotetext{
${ }^{27}$ Defined here as any household with at least one adult of working age (16-64). The financial loss falling on pensioner households is excluded.
} 
By 2020-21, the $£ 240 m$ loss attributable to 'pay to stay' is actually expected to be less than in 2017-18, when the policy is introduced, at which point the Treasury expects savings to peak at $£ 365 \mathrm{~m}^{28}$ and 200,000 households are likely to be affected ${ }^{29}$. The Treasury's expectation is that following the introduction of 'pay to stay' behavioural change will begin to kick in as households take advantage of right to buy or move out. Conversely, the effect of the LHA cap in the social rented sector will escalate well beyond 2020-21 because the policy only applies to new tenancies signed after 1 April 2016. Over time, the number of tenancies affected by the cap will therefore increase, in all likelihood to 2030 and beyond.

Overall, by $2020-21, £ 6.2 \mathrm{bn}$ a year of the $£ 12.9 \mathrm{bn}$ a year financial loss arising from the post2015 welfare reforms - just under half - is estimated to fall on working age social sector households.

Figure 5 shows the estimated financial loss to working age households in the social rented sector by local authority. Once again, these figures are averages that will disguise a wide range of impacts at the level of individual households. The map shows the loss in 2020-21 from all the post-2015 welfare reforms, including the post-March 2016 impact of the changeover to PIP. The figures for each local authority take account of the estimated loss from each reform in each authority, the national share of the loss from each reform falling on social sector households, and the scale of the social sector in each authority. Additionally, the figures take specific account of the financial losses falling on larger families and the variation between local authorities in their housing tenure. The detailed methods are set out in the appendix.

Table 14: Anticipated loss in 2020-21 to working-age households in the social rented sector arising from post-2015 welfare reforms: 20 worst-affected districts

\begin{tabular}{llll}
\hline & $\begin{array}{c}\text { Loss per } \\
\text { working age } \\
\text { household } \\
\boldsymbol{\Sigma} \text { p.a. }\end{array}$ & & $\begin{array}{c}\text { Loss per } \\
\text { working age } \\
\text { household } \\
\text { p.a. }\end{array}$ \\
\hline Newham & 2,740 & Oldham & 2,420 \\
Barking and Dagenham & 2,670 & Middlesbrough & 2,400 \\
Enfield & 2,610 & Burnley & 2,360 \\
Leicester & 2,600 & Knowsley & 2,350 \\
Blackpool & 2,570 & Merthyr Tydfil & 2,350 \\
Luton & 2,570 & Thanet & 2,340 \\
Birmingham & 2,530 & Boston & 2,330 \\
Sandwell & 2,500 & Brent & 2,320 \\
Blackburn with Darwen & 2,500 & Peterborough & 2,290 \\
Bradford & 2,440 & Hull & 2,290 \\
\hline
\end{tabular}

Source: Sheffield Hallam estimates based on official data

\footnotetext{
${ }^{28}$ HM Treasury, Summer Budget 2015

${ }^{29}$ CLG Housing and Planning Bill 2015/16: impact assessment)
} 
Figure 5: Anticipated loss in 2020-21 to working age households in the social rented sector arising from post-2015 welfare reforms, by district

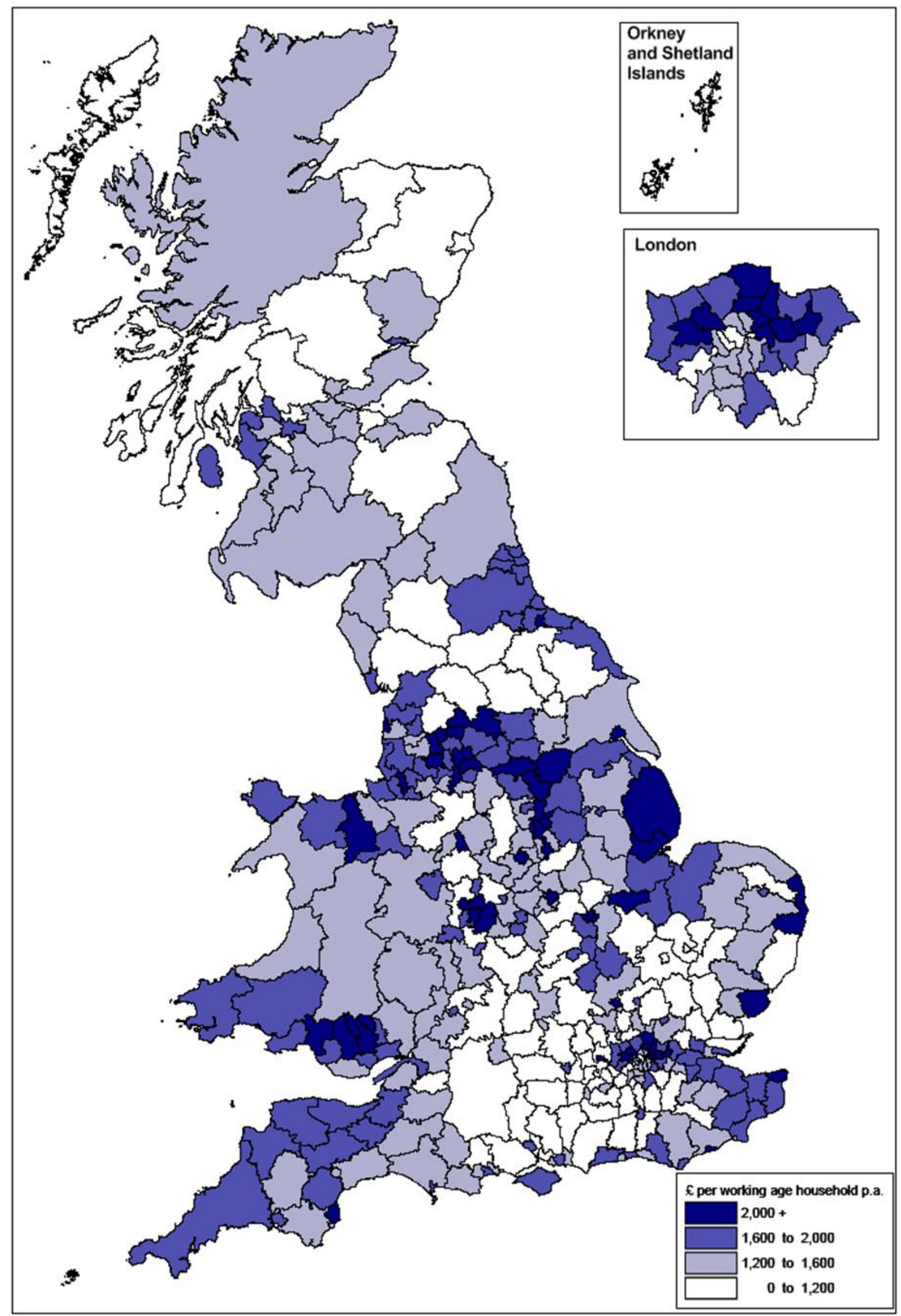

Source: Sheffield Hallam estimates based on official data 
The now familiar pattern is that the biggest losses are in older industrial areas, less prosperous seaside towns, poorer London boroughs and a handful of other towns. In the worst-hit places, shown in Table 14, the losses are typically around £2,500 per household per year. Social sector households in much of southern England around London, and in parts of rural northern England and Scotland, generally face smaller losses though even here the average loss is generally at least $£ 1,000$ a year per household.

\section{Will the loss of income be offset?}

Welfare reform is of course only one of several things happening simultaneously. It is not within the scope of the present report to cover all these in detail but the extent to which the financial losses might be offset, at least for some people, deserves comment.

The increase in personal tax allowances is one offsetting factor. Over the 2010-15 period, the Coalition government increased the personal allowance for Income Tax by more than the rate of inflation. In its 2015 Summer Budget, the Conservative government pledged to increase the allowance from $£ 10,600$ in $2015-16$ to $£ 12,500$ by $2020-21$.

Two points are worth bearing in mind about the impact of changes in personal allowances. The first is that only a proportion of benefit claimants actually pay Income Tax. Those in fulltime employment will typically do so but there are many others - especially women - in lowpaid part-time employment who have an income below tax thresholds. Those on out-of-work benefits will generally be in this position too. The other point is the scale of the tax changes. Raising the personal allowance by $£ 1,900$ a year between 2015-16 and 2020-21 is worth $£ 380$ a year to the individual taxpayer (at a 20 per cent tax rate), but around half of this increase might have been expected anyway if the allowance had been uprated in line with inflation $^{30}$.

The introduction of the National Living Wage is a second offsetting factor. From April 2016 this is $£ 7.20$ an hour for workers aged 25 or more - an increase of 70p compared to the previous minimum wage - and it is the government's aspiration to raise the National Living Wage to over $£ 9$ an hour by 2020. In the short-run the government expects this to boost the earnings of $2.7 \mathrm{~m}$ low wage workers, with knock-on effects further up the wage distribution for perhaps a further $3.25 \mathrm{~m}^{31}$.

Whilst the introduction of the National Living Wage boosts earnings of the low paid, revised tapers and thresholds in Universal Credit increase the withdrawal of financial support from many of the same people. On balance, many of the low paid are likely to find that they are little if at all better off. Illustrative figures in Summer Budget 2015 suggest that the combined effect of welfare reform, personal tax changes and the National Living Wage will be to generate a range of both positive and negative changes in real income by $2020-21$, depending on household structure and hours worked (if any).

\footnotetext{
${ }^{30}$ Office for Budget Responsibility inflation forecast in Summer Budget 2015

${ }^{31}$ Source: HM Treasury (2015) Summer Budget 2015, op. cit.
} 
A third offsetting factor is the reduction in social sector rents, by one per cent a year in England for four years from 2016-17. The Treasury counts this as a 'welfare reform' because the effect is to reduce payments to social sector tenants who claim Housing Benefit. However, unlike the other welfare reforms the claimant does not end up worse off. It is the social sector landlord - a council or housing association - that bears the burden.

There is a group of social sector tenants who do not claim Housing Benefit who will end up better-off as a result of lower rents, and some of these will be households in receipt of benefits that have been reduced or frozen. These households account for just over a third of the $3.9 \mathrm{~m}$ social sector tenants in England ${ }^{32}$. The government expects the rent reduction to benefit this group by $£ 12$ a week by $2020-21$, or just over $£ 600$ a year each ${ }^{33}$, an overall increase in disposable income to the group approaching $£ 900 \mathrm{~m}$ a year. Offsetting this gain, however, the widening gap between social sector and market rents that will result from the rent reduction means that higher-income tenants may face even bigger payments under the new 'pay to stay' arrangements.

For some claimants, Discretionary Housing Payments are a fourth offsetting factor. These are payments administered by local authorities to vulnerable household badly affected by the welfare changes - for example by the Benefit Cap. In the Summer Budget 2015, the government made available $£ 800 \mathrm{~m}$ for this purpose.

Two points need to be noted about Discretionary Housing Payments. First, the government's financial allocation is for a five year period, so on an annual basis it averages only $£ 160 \mathrm{~m}$. This compares to expected annual losses to claimants in $2020-21$ of $£ 495 \mathrm{~m}$ from the new, lower Benefit Cap alone. Second, Discretionary Housing Payments are intended to be a temporary payment to households ${ }^{34}$, whereas the welfare reforms represent a permanent, on-going loss of entitlement.

A fifth offsetting factor is the extension of free childcare. From September 2017, entitlement is being increased from 15 to 30 hours a week for working parents of 3 and 4 year olds. The increase is worth up to $£ 2,500$ a year per child ${ }^{35}$. Tax-free childcare up to the value of $£ 2,000$ per child is also being introduced from early 2017 . The net cost to the Exchequer of the recently-announced changes, including restrictions on the entitlement of the highest-earners, is estimated to be $£ 585 \mathrm{~m}$ a year in $2020-21^{36}$.

For some households these reductions in childcare costs are substantial and they will go a long way towards offsetting, perhaps even entirely, the loss of income arising from the welfare reform package. On the other hand it is worth bearing in mind that the total estimated loss to households with dependent children arising from welfare reform is estimated to be $£ 10.7 \mathrm{bn}$ a year by 2020-21 (see Table 11 earlier). Also, at least some of the financial benefit of the reduction in childcare costs will feed through to middle and upper-

\footnotetext{
${ }^{32}$ Source: English Housing Survey 2013-14

${ }^{33}$ DWP (2015) Welfare Reform and Work Bill: impact assessment of social rent reductions

${ }^{34}$ An exception is the Scottish Government's use to date of Discretionary Housing Payments to offset the 'bedroom tax'

${ }^{35}$ Source: Spending Review and Autumn Statement 2015

${ }^{36}$ Sources: Summer Budget 2015 and Spending Review and Autumn Statement 2015
} 
income households in work who do not draw on the benefit system to any significant extent and are largely unaffected by the welfare reforms.

Taken as a whole, all these parallel changes in taxation, wages and entitlement go some way to offsetting the financial losses arising from welfare reform. However, it is clear that the winners and the losers are unlikely to be the same people. It also looks unlikely that the full financial loss will be offset in this way.

\section{Will more people find employment?}

Westminster ministers take the view that the welfare reforms increase the financial incentive to take up employment and because more people will look for work more people will find work. In this view, employment will be higher and the loss of benefit income will be offset in whole or in part by an increase in earnings.

What is true is that since 2012, at around the time that many of the first round of welfare reforms began to bite, UK employment has grown strongly - more strongly indeed than normal given the modest growth in output. It would be wrong, however, to assume that welfare reform has been the trigger. Other factors almost certainly lie at the root of the upturn - the revival in household borrowing, especially around the housing market, the recovery of the world economy and exceptionally low interest rates for example. The reforms to out-of-work benefits do however increase the financial incentive to work.

On the other hand, even before the reforms began most out-of-work claimants would have been financially better off in employment. Financial disincentives only came into play for relatively small numbers at specific cut-off points in the system. Moreover, some reforms to in-work benefits - the changes to Universal Credit tapers and thresholds for example - tend to have the opposite effect, making work less financially rewarding, and many in employment may find it difficult to increase their working hours to offset the loss of income.

For claimants of Employment and Support Allowance, who are by far the largest group on out-of-work benefits, it is also questionable whether increasing the financial incentive to work really addresses their obstacles to employment. For some ESA claimants health problems or disabilities pose a formidable barrier, and even for those closer to the labour market there are generally unresolved health issues. Additionally, ESA claimants are disproportionately concentrated in the weaker local labour markets up and down the country, where employers are generally able to recruit plenty of fit and healthy workers.

Central to the view that employment will rise in the wake of the welfare reforms is the assumption that extra labour supply leads to extra labour demand from employers. Whether labour markets really do work in this way is deeply questionable. There are times and places where a shortage of labour can bottle-up economic growth but particularly where the local economy is weak - which is where so many out-of-work claimants are concentrated the likelihood of an increase in labour supply triggering an increase in employment is low. Some individuals will undoubtedly find work to compensate for the loss of benefit income but whether the overall level of employment will be any higher as a result is questionable. More 
often than not, the claimants finding work will simply fill vacancies that would have gone to other jobseekers, thereby transferring unemployment from one person to another.

Hard evidence is limited. A pilot study in Scotland ${ }^{37}$ found that the unemployment (JSA) claimant rate had fallen fastest in the local authorities where the financial losses from welfare reform were largest. Closer examination, however, showed that the same areas - which were the places that started with the highest unemployment - also experienced the biggest reductions in unemployment in previous economic upturns, long before the implementation of welfare reform.

\section{The knock-on consequences for local economies}

The loss of income arising from welfare reform can be expected to have a negative impact on employment, independently of the changing financial incentive to find a job or increase working hours. Many jobs are directly supported by consumer spending. So if incomes fall because of welfare reform, and if this leads to in a reduction in spending, jobs are likely to be at risk as a result.

Estimating these 'knock-on' consequences is not straightforward. However, in a study on the impact of the pre-2015 welfare reforms on Wales we estimated that the loss of just over $£ 1$ bn a year in income from benefits might lead to the loss of around 7,000 jobs in consumer services $^{38}$. There were a number of steps in this calculation:

- The loss of income from welfare reform as a share of total disposable household income

- The assumption that household spending falls in line with the reduction in income which is plausible given that the reforms often affect lower-income households

- The assumption that spending on consumer services falls in line with overall spending

- The assumption that in the long-run employment in consumer services ${ }^{39}$ adjusts downwards to reflect lower spending

Table 15 applies the same ready-reckoner - that $£ 1 b n$ a year loss of benefit income leads to 7,000 job losses in consumer services - to all the GB regions. This table looks at the potential impact of the financial losses arising from all the pre and post-2015 welfare reforms. There will be lags in the response of employment to changes in benefit income, and indeed the full impact is unlikely to be felt until after 2020. It also makes sense to look at the regional impacts because consumer spending tends to spill over from one local authority

\footnotetext{
${ }^{37} \mathrm{C}$ Beatty, S Fothergill and D Houston (2015) op. cit.

${ }^{38} \mathrm{C}$ Beatty and S Fothergill (2014) The Impact of Welfare Reform on the Valleys, op. cit.

${ }^{39}$ Motor trade (45), Retailing (47), Food and beverage services (56), Gambling and betting (92), Sports and recreation (93), Repair of household goods (95), Other personal services (96). Numbers in brackets refer to industry codes in the 2007 Standard Industrial Classification.
} 
to another. In this table the regions are ranked according to the total loss per working age adult arising from welfare reform (see Table 8 earlier), from the worst affected (North West) to the least affected (South East). The absolute numbers in Table 15 are strongly influenced by the size of each region.

The potential job losses are not negligible. Across Britain as a whole, approaching 200,000 jobs in local consumer services might be lost as a result of welfare reform.

It is worth emphasising, nevertheless, that these job losses are likely only over a long period at the same time as several other factors - wages, taxation and household borrowing for example - can also be expected to influence consumer spending. Few if any businesses are likely to close or make redundancies solely because of the impact of welfare reform but the reforms are a significant factor in defining the environment in which many businesses operate.

Table 15: Possible job loss in local consumer services arising from all pre and post-2015 welfare reforms, by region

\begin{tabular}{|c|c|}
\hline & $\begin{array}{c}\text { Number of job } \\
\text { losses }\end{array}$ \\
\hline North West & 25,000 \\
\hline North East & 9,000 \\
\hline Wales & 10,000 \\
\hline West Midlands & 19,000 \\
\hline Yorkshire and the Humber & 18,000 \\
\hline London & 30,000 \\
\hline East Midlands & 14,000 \\
\hline Scotland & 15,000 \\
\hline South West & 15,000 \\
\hline East & 15,000 \\
\hline South East & 22,000 \\
\hline Great Britain & 190,000 \\
\hline
\end{tabular}

Source: Sheffield Hallam estimates based on official data

\section{Concluding remarks}

The impacts of welfare reform continue to be substantial - an estimated loss of income by the beginning of the next decade of almost $£ 13 b n$ a year as a result of the post-2015 reforms, and cumulatively more than $£ 27 \mathrm{bn}$ a year as a result of all the reforms since 2010 . Once all the reforms have been fully implemented, this equates to an average of $£ 690$ a year for every adult of working age across the whole of Britain. For some of the individuals affected by the changes the loss of income is much, much greater. 
What is clear is that the financial losses arising from the reforms hit some places much harder than others. At the extremes, the loss per head is three times as much in some places as in others.

Each of the individual reforms has its own distinctive geography. Some hit places with large numbers out-of-work, others where housing costs are high, some where low pay is prevalent and a number of the post-2015 reforms in particular hit places where large families are concentrated. Taking the reforms as a whole, many of Britain's older industrial areas, a number of less prosperous seaside towns and some London boroughs are hit hardest. Much of south and east England outside London escapes comparatively lightly.

As a general rule, the most deprived local authorities across Britain are hit hardest. A key effect of welfare reform is therefore to widen the gaps in prosperity between the best and worst local economies across the country.

What is also clear is that the post-2015 round of welfare reform impacts very unevenly on different types of households. It is families with dependent children, including lone parents, who face the largest financial losses. And, on average, households living in the social rented sector can expect losses that are far bigger than those facing owner-occupiers.

The net effect is that many individuals and households in the more prosperous parts of the country will barely notice that welfare reform is underway. For others however, the financial consequences will be only too obvious. 


\begin{tabular}{lccc}
\hline & \multicolumn{3}{c}{ Housing Benefit: LHA } \\
\cline { 2 - 4 } & $\begin{array}{c}\text { No of } \\
\text { households affected }\end{array}$ & $\begin{array}{c}\text { Estimated } \\
\text { loss } \\
\text { Em p.a. }\end{array}$ & $\begin{array}{c}\text { Loss per } \\
\text { working age adult } \\
\mathbf{E} \text { p.a. }\end{array}$ \\
\hline London & 237,000 & 490 & 85 \\
North West & 191,000 & 190 & 43 \\
North East & 72,000 & 70 & 41 \\
South West & 126,000 & 130 & 39 \\
South East & 173,000 & 200 & 37 \\
Yorkshire \& Humber & 133,000 & 120 & 35 \\
Wales & 73,000 & 70 & 35 \\
West Midlands & 115,000 & 120 & 33 \\
East Midlands & 91,000 & 90 & 29 \\
East & 105,000 & 110 & 29 \\
Scotland & 83,000 & 80 & $\mathbf{4 2}$ \\
\hline Great Britain & $\mathbf{1 , 4 0 0 , 0 0 0}$ & $\mathbf{1 , 6 7 0}$ & \\
\hline
\end{tabular}

\begin{tabular}{rlc}
\hline WORST AFFECTED & $\begin{array}{c}\text { Loss per } \\
\text { working } \\
\text { 20 LO adult } \\
\text { £ p.a. }\end{array}$ \\
\hline 1. & Westminster & 415 \\
2. & Kensington and Chelsea & 255 \\
3. & Blackpool & 185 \\
4. & Brent & 175 \\
5. & Brighton and Hove & 130 \\
6. & Hackney & 120 \\
7. & Hastings & 110 \\
8. & Haringey & 105 \\
9. & Lewisham & 105 \\
10. & Camden & 100 \\
11. & Enfield & 100 \\
12. & Torbay & 95 \\
13. & Ealing & 95 \\
14. & Wandsworth & 90 \\
15. & Thanet & 85 \\
16. & Bournemouth & 80 \\
17. & Southend-on-Sea & 80 \\
18. & Croydon & 80 \\
19. & Tendring & 80 \\
20. & Islington & 80 \\
\hline
\end{tabular}

The reforms to the Local Housing Allowance (LHA) element of Housing Benefit have impacted most where the private rented sector accounts for a high proportion of households and where rent levels are highest.

Unsurprisingly, the biggest impact of this reform has fallen on London and in particular on boroughs such as Westminster and Kensington and Chelsea where rents are exceptionally high.

A number of seaside towns have also been hit hard. They too have large numbers in private rented housing. Some of this comprises former g0uest houses that have been sub-divided into small flats and draw in low-income and out-of-work households from surrounding areas and further afield.

Britain's older industrial areas, hit hard by many of the other welfare changes, have been less acutely affected by the LHA reforms because a higher proportion of their low-income households live in the social rented sector or in lower-price owneroccupied property. 


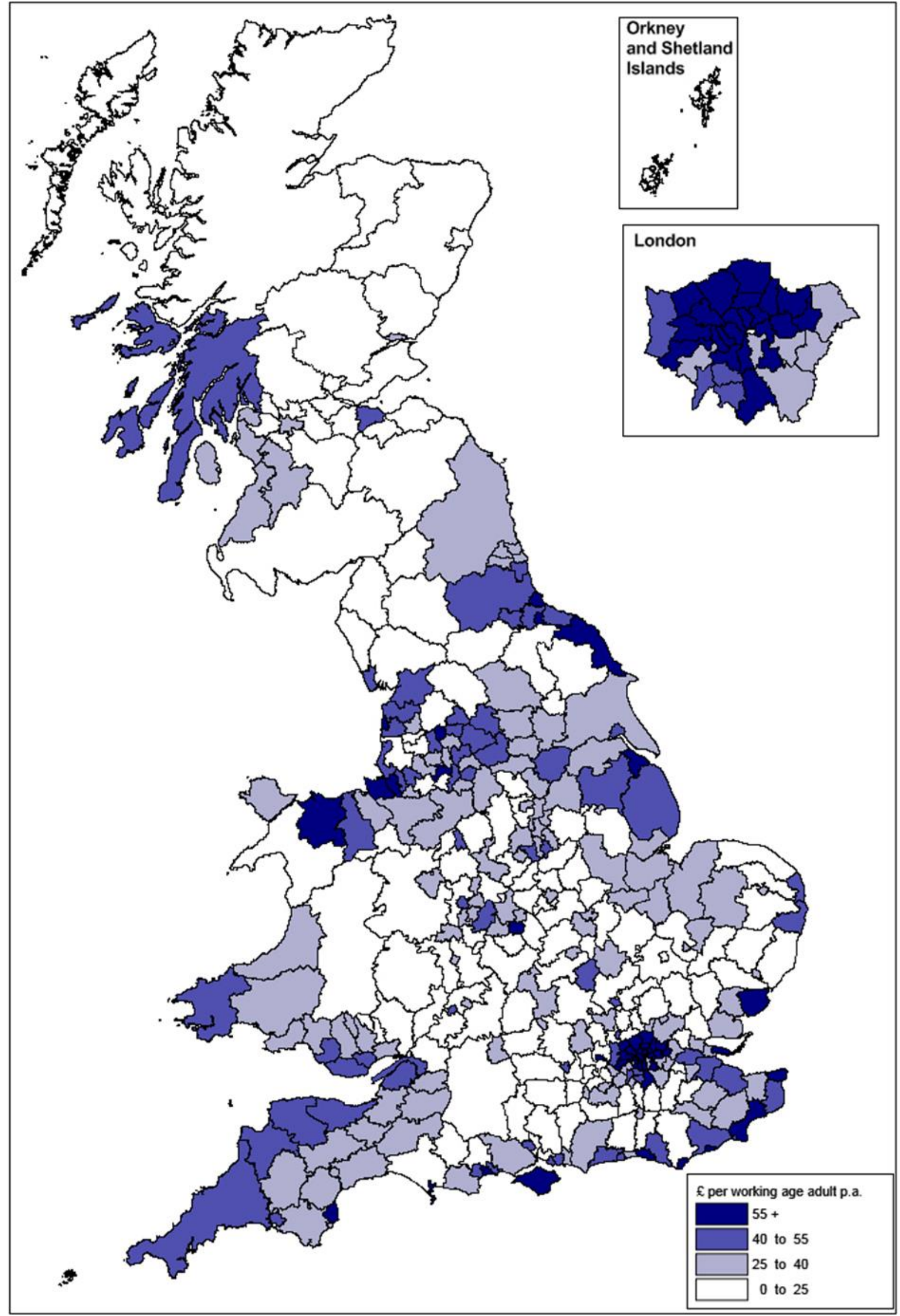

Source: Sheffield Hallam estimates based on official data 


\begin{tabular}{lccc}
\hline & \multicolumn{2}{c}{ Housing Benefit: 'bedroom tax' } \\
\cline { 2 - 4 } & $\begin{array}{c}\text { No of } \\
\text { households affected }\end{array}$ & $\begin{array}{c}\text { Estimated } \\
\text { loss } \\
\text { Em p.a. }\end{array}$ & $\begin{array}{c}\text { Loss per } \\
\text { working age adult } \\
\text { £ p.a. }\end{array}$ \\
\hline North East & 40,000 & 25 & 16 \\
North West & 86,000 & 65 & 14 \\
Yorkshire \& Humber & 53,000 & 35 & 11 \\
London & 58,000 & 60 & 11 \\
Wales & 35,000 & 25 & 11 \\
West Midlands & 55,000 & 40 & 10 \\
East Midlands & 37,000 & 25 & 8 \\
East & 35,000 & 30 & 7 \\
South West & 28,000 & 20 & 7 \\
South East & 38,000 & 35 & 5 \\
Scotland & 0 & 0 & $\mathbf{9}$ \\
\hline Great Britain & $\mathbf{4 6 0 , 0 0 0}$ & 360 & 0 \\
\hline
\end{tabular}

\begin{tabular}{rlc}
\hline WORST AFFECTED & $\begin{array}{c}\text { Loss per } \\
\text { working } \\
\text { age adult } \\
\text { 20 L.a. }\end{array}$ \\
\hline 1. & Knowsley & 31 \\
2. & Liverpool & 25 \\
3. & Copeland & 25 \\
4. & Middlesbrough & 24 \\
5. & St Helens & 24 \\
6. & South Tyneside & 24 \\
7. & Halton & 23 \\
8. & Manchester & 22 \\
9. & Hackney & 22 \\
10. & Torfaen & 22 \\
11. & Salford & 22 \\
12. & Norwich & 21 \\
13. & Blaenau Gwent & 21 \\
14. & Newcastle upon Tyne & 21 \\
15. & Lambeth & 21 \\
16. & Southwark & 21 \\
17. & Merthyr Tydfil & 20 \\
18. & Wakefield & 20 \\
19. & Sandwell & 19 \\
20. & Allerdale & 19 \\
\hline
\end{tabular}

The new rules affecting under-occupation of social housing (widely known as the 'bedroom tax') have impacted most in the places where a high proportion of the housing stock is rented from councils or housing associations. These areas include much of older industrial Britain and a number of London boroughs.

Older industrial areas have generally been hit especially hard because they mostly have high worklessness as well as a high proportion in social housing.

Large parts of southern and eastern England have been less affected by this reform. They have relatively little social housing and relatively few people out-of-work on benefits.

In Scotland, the impact on claimants has been fully averted by the Scottish Government's use of Discretionary Housing Payments.

Sources: Sheffield Hallam estimates based on official data 
Housing Benefit: 'bedroom tax' - outturn to March 2016

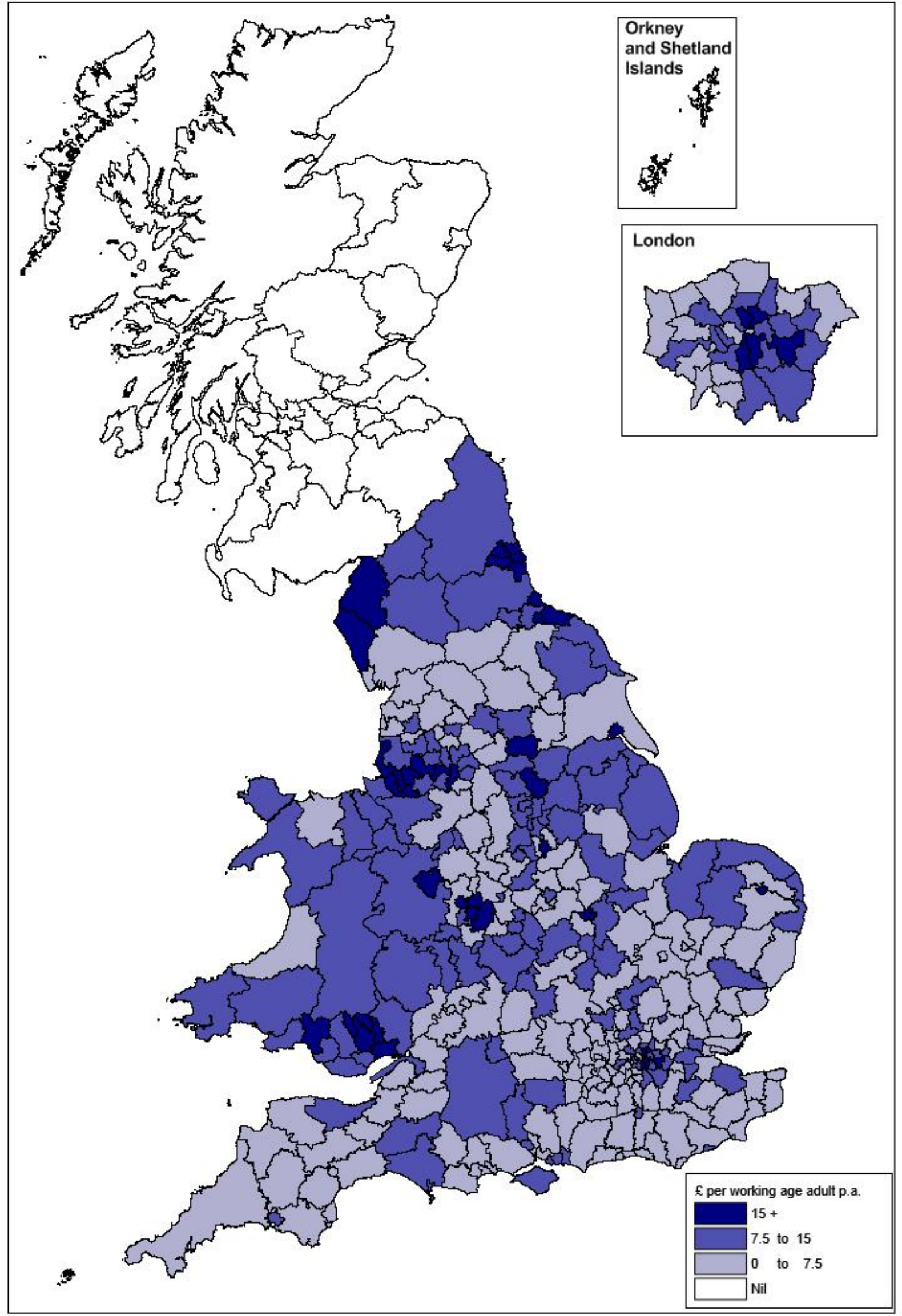

Source: Sheffield Hallam estimates based on official data 


\begin{tabular}{lccc}
\hline & \multicolumn{3}{c}{ Non-dependant deductions } \\
\cline { 2 - 4 } & $\begin{array}{c}\text { No of } \\
\text { households affected }\end{array}$ & $\begin{array}{c}\text { Estimated } \\
\text { loss } \\
\text { Em p.a. }\end{array}$ & $\begin{array}{c}\text { Loss per } \\
\text { working age adult } \\
\mathbf{E} \text { p.a. }\end{array}$ \\
\hline North East & 16,000 & 11 & 7 \\
North West & 39,000 & 28 & 6 \\
Yorkshire \& Humber & 27,000 & 19 & 6 \\
West Midlands & 29,000 & 20 & 6 \\
Wales & 16,000 & 11 & 6 \\
Scotland & 28,000 & 20 & 6 \\
East Midlands & 20,000 & 14 & 5 \\
London & 45,000 & 31 & 5 \\
South West & 23,000 & 16 & 5 \\
East & 24,000 & 17 & 4 \\
South East & 32,000 & 22 & $\mathbf{5}$ \\
\hline Great Britain & $\mathbf{3 0 0 , 0 0 0}$ & $\mathbf{2 1 0}$ & \\
\hline
\end{tabular}

\begin{tabular}{rlc}
\hline WORST AFFECTED & $\begin{array}{c}\text { Loss per } \\
\text { working } \\
\text { age adult } \\
\text { 20 L.a. }\end{array}$ \\
\hline 1. & Blackpool & 10 \\
2. & Knowsley & 9 \\
3. & Hartlepool & 9 \\
4. & South Tyneside & 9 \\
5. & Glasgow & 8 \\
6. & West Dunbartonshire & 8 \\
7. & Torbay & 8 \\
8. & Middlesbrough & 8 \\
9. & Tendring & 8 \\
10. & Thanet & 8 \\
11. & Liverpool & 8 \\
12. & Blaenau Gwent & 8 \\
13. & Great Yarmouth & 8 \\
14. & Hastings & 8 \\
15. & Hull & 8 \\
16. & Inverclyde & 8 \\
17. & North Ayrshire & 8 \\
18. & Salford & 8 \\
19. & Dundee & 8 \\
20. & Hackney & 8 \\
\hline
\end{tabular}

The increase in non-dependent

deductions, which mainly affect Housing Benefit entitlements, has impacted principally on the places with high numbers out-of-work on benefits.

The worst affected places include Britain's older industrial areas but also a number of seaside towns where there is not only unemployment but also a high proportion claiming Housing Benefit.

A number of the less affluent London boroughs have also been hit relatively hard.

Large parts of southern and eastern England outside London have been little affected by the increase in the deductions. A number of rural areas in the North of England and in Scotland have also escaped relatively lightly. 


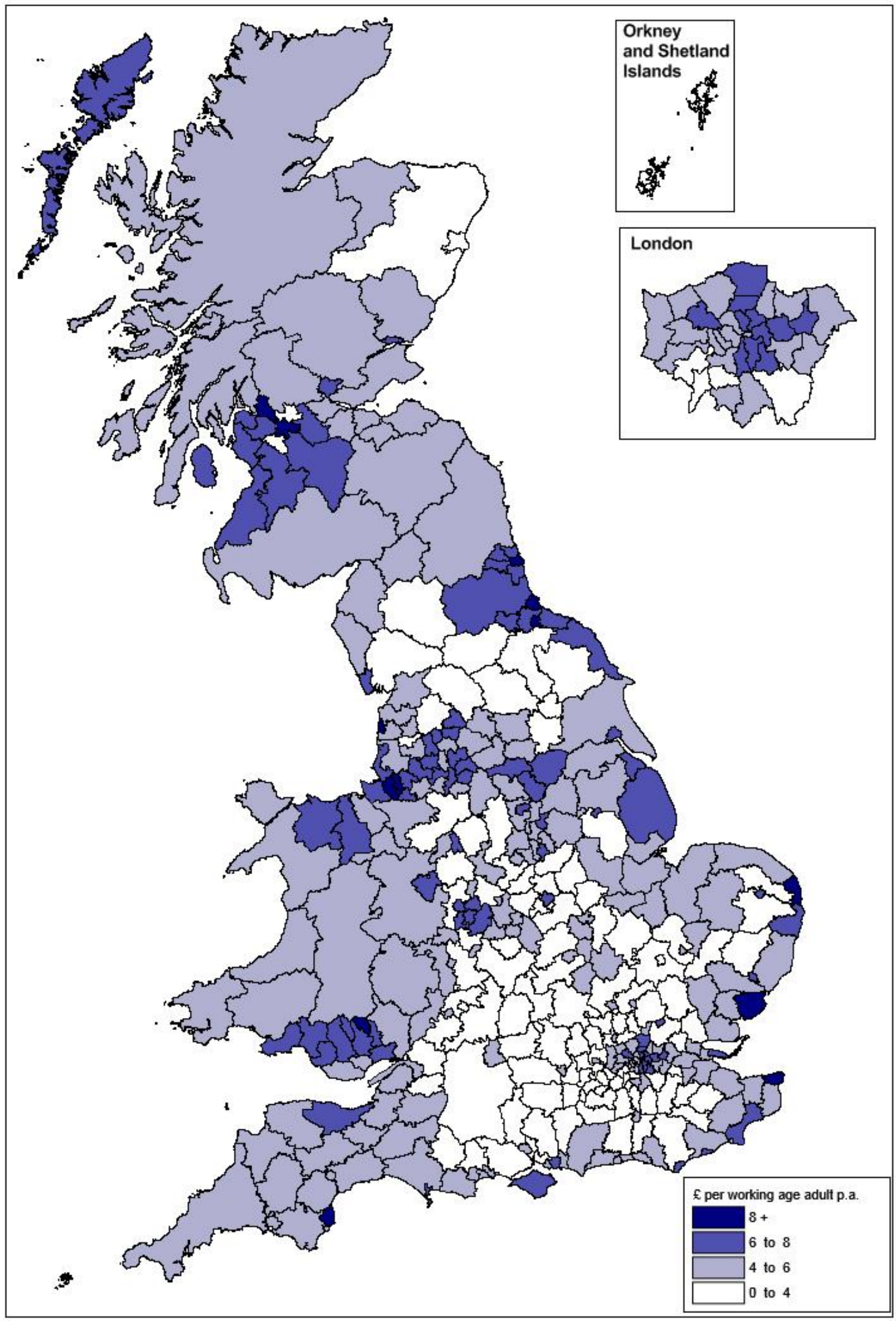

Source: Sheffield Hallam estimates based on official data 


\begin{tabular}{lccc}
\hline & \multicolumn{3}{c}{ Benefit Cap } \\
\cline { 2 - 4 } & $\begin{array}{c}\text { No of } \\
\text { households affected }\end{array}$ & $\begin{array}{c}\text { Estimated } \\
\text { Ioss } \\
\mathbf{E m ~ p . a . ~}\end{array}$ & $\begin{array}{c}\text { Loss per } \\
\text { working age adult } \\
\mathbf{E} \text { p.a. }\end{array}$ \\
\hline London & 13,000 & 52 & 9 \\
West Midlands & 2,100 & 6 & 2 \\
South East & 2,700 & 9 & 2 \\
North East & 700 & 2 & 1 \\
North West & 2,000 & 6 & 1 \\
Yorkshire \& Humber & 1,500 & 4 & 1 \\
East Midlands & 1,100 & 3 & 1 \\
East & 1,800 & 5 & 1 \\
South West & 1,100 & 3 & 1 \\
Wales & 800 & 2 & $\mathbf{2}$ \\
Scotland & 900 & 3 & 1 \\
\hline Great Britain & $\mathbf{2 8 , 0 0 0}$ & & \\
\hline
\end{tabular}

\begin{tabular}{rlc}
\hline WORST AFFECTED & $\begin{array}{c}\text { Loss per } \\
\text { working } \\
\text { age adult } \\
\text { E } \mathbf{p} \text {.a. }\end{array}$ \\
\hline 1. & Westminster & 28 \\
2. & Brent & 21 \\
3. & Ealing & 17 \\
4. & Enfield & 17 \\
5. & Tower Hamlets & 15 \\
6. & Kensington and Chelsea & 15 \\
7. & Hammersmith and Fulham & 14 \\
8. & Haringey & 14 \\
9. & Barking and Dagenham & 11 \\
10. & Newham & 10 \\
11. & Redbridge & 9 \\
12. & Hackney & 9 \\
13. & Waltham Forest & 8 \\
14. & Harrow & 8 \\
15. & Slough & 8 \\
16. & Lewisham & 8 \\
17. & Barnet & 7 \\
18. & Wandsworth & 7 \\
19. & Islington & 6 \\
20. & Croydon & 6 \\
\hline
\end{tabular}

The Benefit Cap has so far impacted overwhelmingly on London. All but one of the worst affected 20 local authorities are London boroughs.

London has been hit hard because the pre2016 cap mostly comes into play for households that have hitherto been claiming large sums in Housing Benefit because of high rent levels.

Unsurprisingly, Westminster, with the highest rent levels of all, has faced the biggest impact. But in all parts of Britain the number of households affected is well down on what was originally expected.

The pre-2016 Benefit Cap has barely impacted at all across large swathes of Britain away from London. 


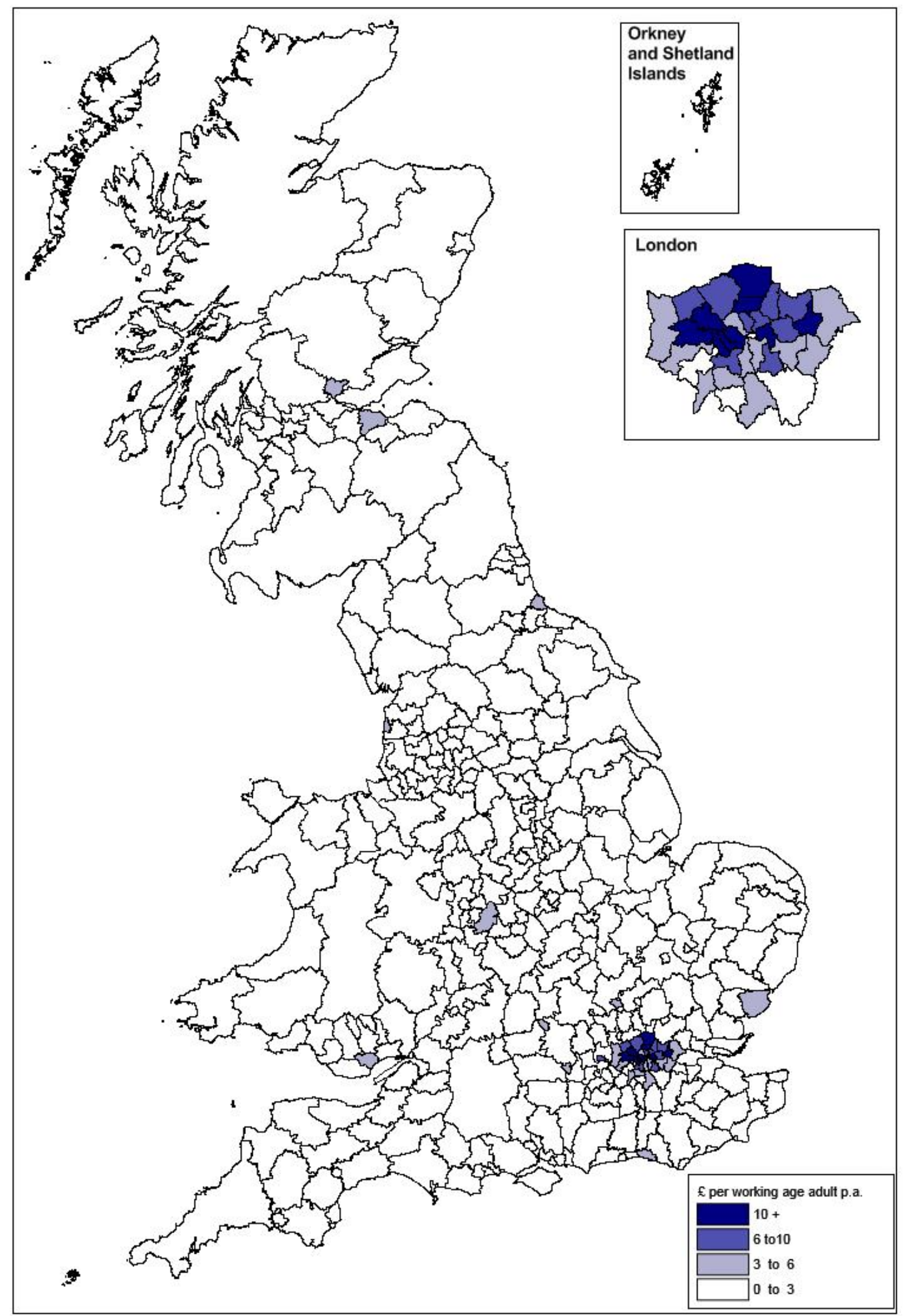

Source: Sheffield Hallam estimates based on official data 


\begin{tabular}{|c|c|c|c|c|}
\hline & & \multicolumn{3}{|c|}{ Council Tax Support } \\
\hline & & $\begin{array}{c}\text { No of } \\
\text { households affected }\end{array}$ & $\begin{array}{l}\text { Estimated } \\
\text { loss } \\
\text { Em p.a. }\end{array}$ & $\begin{array}{l}\text { Loss per } \\
\text { working age adult } \\
£ \text { p.a. }\end{array}$ \\
\hline \multicolumn{2}{|c|}{ Yorkshire \& Humber } & 270,000 & 50 & 15 \\
\hline \multicolumn{2}{|c|}{ North West } & 350,000 & 55 & 12 \\
\hline \multicolumn{2}{|c|}{ West Midlands } & 250,000 & 45 & 12 \\
\hline \multicolumn{2}{|c|}{ London } & 440,000 & 70 & 12 \\
\hline \multicolumn{2}{|c|}{ North East } & 130,000 & 20 & 11 \\
\hline \multicolumn{2}{|c|}{ South West } & 170,000 & 35 & 10 \\
\hline \multicolumn{2}{|c|}{ East Midlands } & 190,000 & 30 & 9 \\
\hline \multicolumn{2}{|c|}{ East } & 200,000 & 35 & 9 \\
\hline \multicolumn{2}{|c|}{ South East } & 240,000 & 40 & 7 \\
\hline Wa & & 0 & 0 & 0 \\
\hline $\mathrm{Scc}$ & and & 0 & 0 & 0 \\
\hline Gre & Britain & $2,250,000$ & 370 & 9 \\
\hline $\begin{array}{l}\text { WO } \\
20 \mathrm{~L} \\
\end{array}$ & $\begin{array}{l}\text { ST AFFECTED } \\
\text { CAL AUTHORITIES }\end{array}$ & $\begin{array}{l}\text { Loss per } \\
\text { working } \\
\text { age adult } \\
£ \text { p.a. }\end{array}$ & & $\begin{array}{l}\text { he Westminster government imposed a } 10 \\
\text { er cent cut in funding for Council Tax } \\
\text { upport to all parts of the country. Whether } \\
\text { is had fed through to claimants has }\end{array}$ \\
\hline 1. & Blackpool & 40 & & epended on whether it was passed on. \\
\hline 2. & Wolverhampton & 36 & & Scotland and Wales the devolved \\
\hline 3. & South Tyneside & 32 & & dministrations chose not to pass on the cut \\
\hline 4. & Barking and Dagenham & 31 & & local authorities - so no impact on \\
\hline 5. & Haringey & 29 & & laimants there. \\
\hline 6. & Stoke-on-Trent & 29 & & ome local authorities in England chose not \\
\hline 7. & Middlesbrough & 28 & & pass on the reduction, in whole or in part, \\
\hline 8. & Torbay & 28 & & bsorbing the loss by cuts elsewhere in their \\
\hline 9. & Walsall & 27 & & udget. \\
\hline & North East Lincolnshire & 27 & & o the map partly reflects political choice. \\
\hline 11. & Harlow & 26 & & ut it also reflects the government's \\
\hline & Rochdale & 26 & & sistence that none of the reduction is \\
\hline & Knowsley & 25 & & assed on to pensioner households, so the \\
\hline & Enfield & 24 & & ull burden of the adjustment has to fall on \\
\hline & Shepway & 24 & & \\
\hline & Peterborough & 24 & & the parts of Britain where the reductions \\
\hline & Leicester & 23 & & ave been passed on, and where there are \\
\hline & Barnsley & 23 & & $\begin{array}{l}\text { arge numbers of working-age claimants, the } \\
\text { npact is areatest. }\end{array}$ \\
\hline & Oldham & 23 & & \\
\hline 20. & Southend & 22 & & \\
\hline
\end{tabular}

Sources: Sheffield Hallam estimates based on New Policy Institute data 


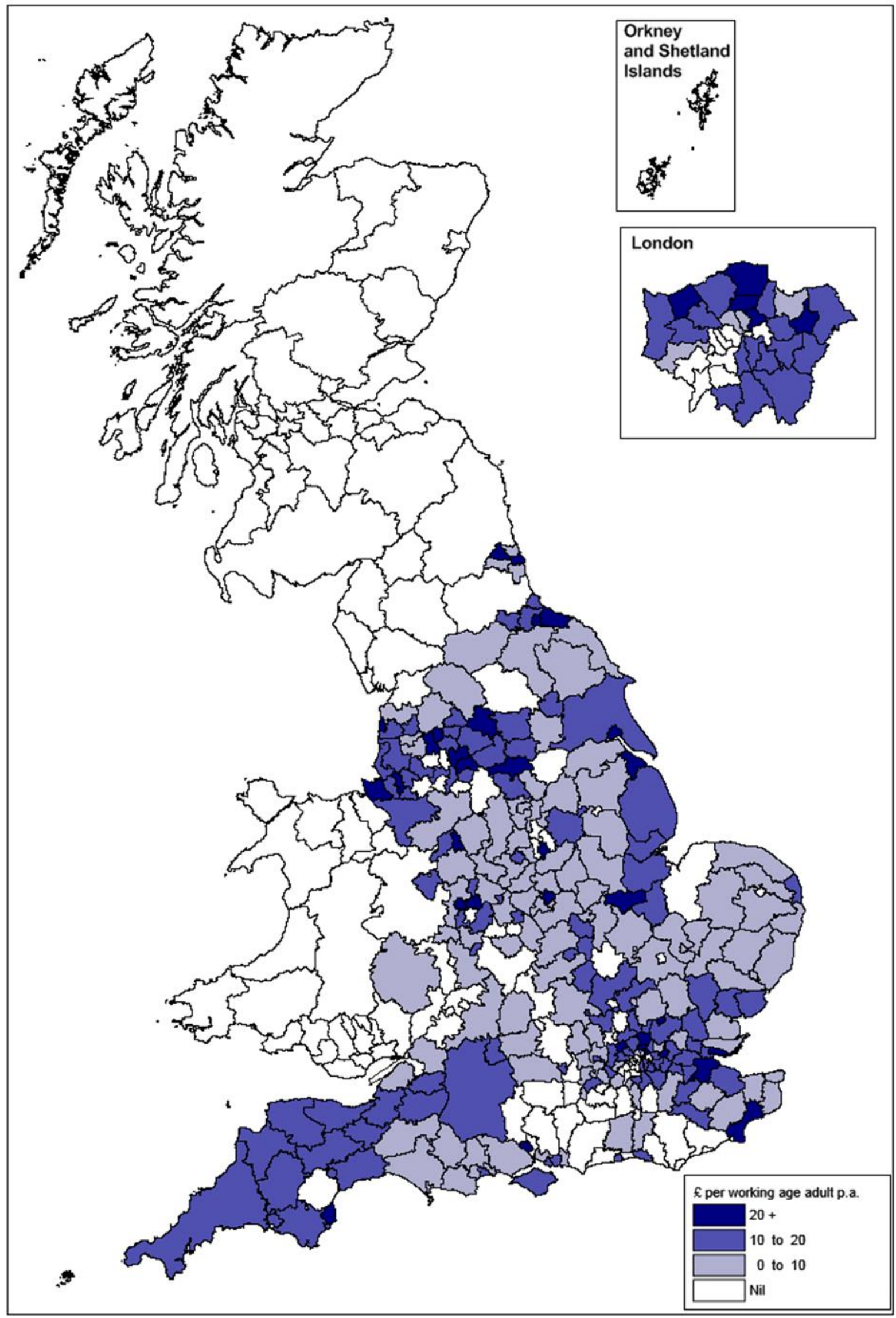

Source: Sheffield Hallam estimates based on New Policy Institute data 


\begin{tabular}{lccc}
\hline & \multicolumn{3}{c}{ Personal Independence Payment } \\
\cline { 2 - 4 } & $\begin{array}{c}\text { No of } \\
\text { individuals affected }\end{array}$ & $\begin{array}{c}\text { Estimated } \\
\text { Ioss } \\
\text { Em p.a. }\end{array}$ & $\begin{array}{c}\text { Loss per } \\
\text { working age adult } \\
\mathbf{E ~ p . a . ~}\end{array}$ \\
\hline Wales & 77,000 & 200 & 103 \\
North East & 59,000 & 150 & 92 \\
North West & 160,000 & 410 & 91 \\
Scotland & 122,000 & 320 & 91 \\
Yorkshire \& Humber & 100,000 & 260 & 77 \\
West Midlands & 104,000 & 270 & 75 \\
East Midlands & 81,000 & 210 & 72 \\
South West & 88,000 & 230 & 68 \\
East & 81,000 & 210 & 56 \\
South East & 117,000 & 300 & 55 \\
London & 121,000 & 310 & 54 \\
\hline Great Britain & $\mathbf{1 , 1 1 0 , 0 0}$ & $\mathbf{2 , 8 7 0}$ & $\mathbf{7 2}$ \\
\hline
\end{tabular}

\begin{tabular}{rlc}
\hline WORST AFFECTED & $\begin{array}{c}\text { Loss per } \\
\text { working } \\
\text { age adult } \\
\text { 20 L.a. }\end{array}$ \\
\hline 1. & Neath Port Talbot & 154 \\
2. & Merthyr Tydfil & 147 \\
3. & Knowsley & 141 \\
4. & Blackpool & 136 \\
5. & Blaenau Gwent & 134 \\
6. & West Dunbartonshire & 133 \\
7. & Caerphilly & 130 \\
8. & Glasgow & 128 \\
9. & Barrow-in-Furness & 127 \\
10. & Rhondda Cynon Taf & 124 \\
11. & Inverclyde & 124 \\
12. & Bridgend & 121 \\
13. & East Lindsey & 121 \\
14. & Torfaen & 120 \\
15. & Torbay & 119 \\
16. & Liverpool & 119 \\
17. & Denbighshire & 117 \\
18. & Bolsover & 117 \\
19. & Carmarthenshire & 113 \\
20. & Mansfield & 113 \\
\hline
\end{tabular}

The replacement of Disability Living Allowance (DLA) by Personal Independence Payments (PIP) impacts most on the places where the number of claimants is greatest.

The DLA claimant rate varies greatly across Britain, generally in line with the incapacity (ESA) claimant rate because most DLA claimants of working age are out-of-work on Employment and Support Allowance.

The big numbers are in Britain's older industrial areas. The South Wales Valleys, along with industrial areas in the North and Scotland and a number of seaside towns, lose most.

The financial loss in much of southern England, including most of London, is often only a quarter or a third that in the worst hit areas.

The changeover to PIP is a pre-2015 reform that is not expected to come to full fruition until 2018. 
Personal Independence Payment - anticipated impact by 2020-21

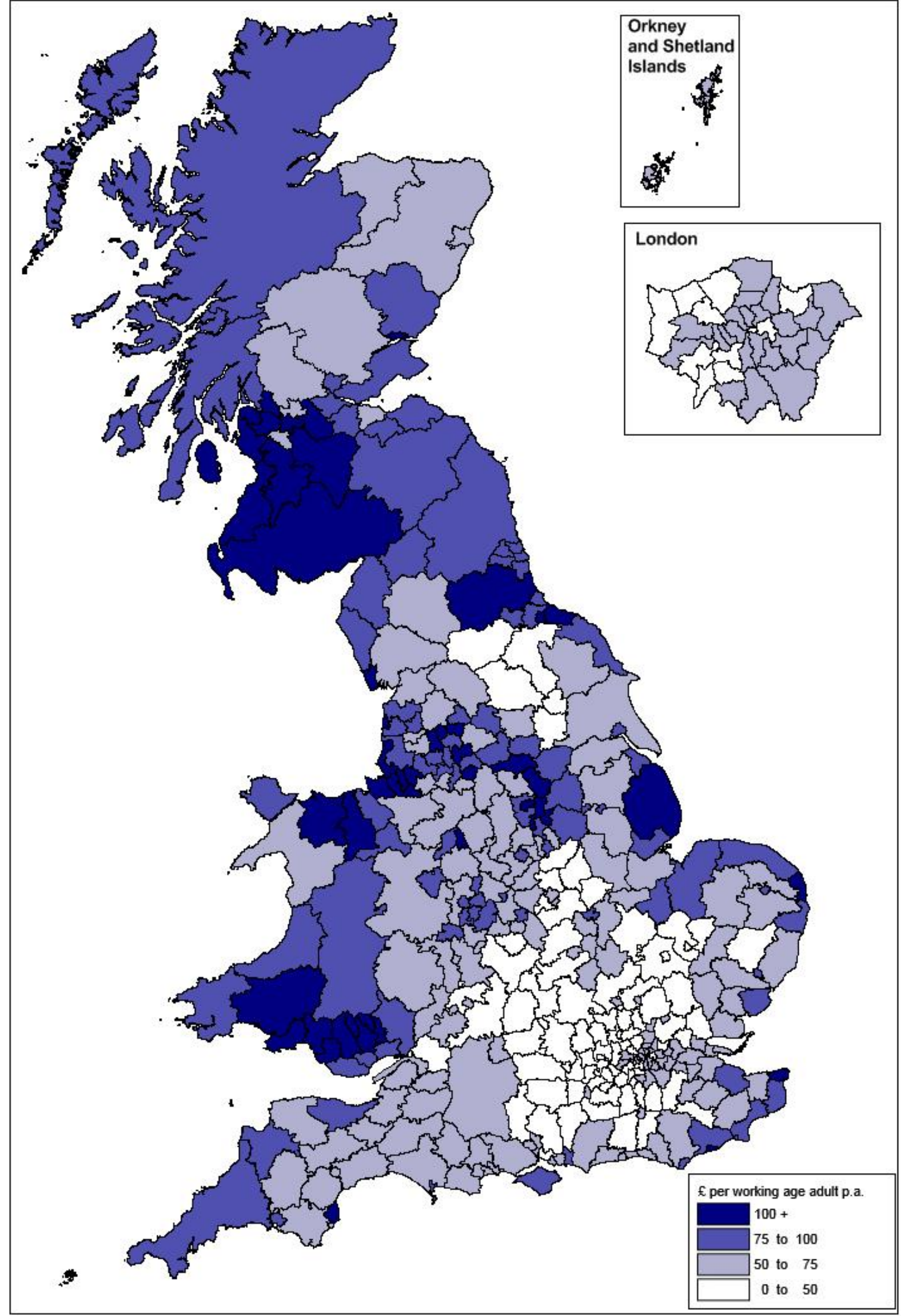

Source: Sheffield Hallam estimates based on official data 


\begin{tabular}{|c|c|c|c|}
\hline & \multicolumn{3}{|c|}{ Employment and Support Allowance } \\
\hline & $\begin{array}{c}\text { No of } \\
\text { individuals affected }\end{array}$ & $\begin{array}{l}\text { Estimated } \\
\text { loss } \\
\text { Em p.a. }\end{array}$ & $\begin{array}{c}\text { Loss per } \\
\text { working age adult } \\
£ \text { p.a. }\end{array}$ \\
\hline Wales & 23,000 & 50 & 25 \\
\hline Scotland & 41,000 & 85 & 25 \\
\hline North East & 18,000 & 35 & 22 \\
\hline North West & 46,000 & 95 & 21 \\
\hline East Midlands & 23,000 & 50 & 17 \\
\hline Yorkshire \& Humber & 26,000 & 55 & 16 \\
\hline West Midlands & 28,000 & 60 & 16 \\
\hline South West & 22,000 & 45 & 14 \\
\hline East & 21,000 & 45 & 12 \\
\hline London & 33,000 & 70 & 12 \\
\hline South East & 29,000 & 60 & 11 \\
\hline Great Britain & 310,000 & 650 & 16 \\
\hline
\end{tabular}

\begin{tabular}{rlc}
\hline WORST AFFECTED & $\begin{array}{c}\text { Loss per } \\
\text { working } \\
\text { age adult } \\
\text { 20 L.a. }\end{array}$ \\
\hline 1. & Glasgow & 42 \\
2. & Blaenau Gwent & 42 \\
3. & Merthyr Tydfil & 38 \\
4. & Neath Port Talbot & 36 \\
5. & Dundee & 34 \\
6. & Rhondda Cynon Taf & 34 \\
7. & Blackpool & 34 \\
8. & Burnley & 33 \\
9. & Inverclyde & 32 \\
10. & Clackmannanshire & 32 \\
11. & Knowsley & 32 \\
12. & West Dunbartonshire & 31 \\
13. & Caerphilly & 31 \\
14. & Hastings & 31 \\
15. & North Ayrshire & 30 \\
16. & Blackburn with Darwen & 30 \\
17. & Bridgend & 29 \\
18. & North Lanarkshire & 29 \\
19. & Liverpool & 29 \\
20. & East Ayrshire & 29 \\
\hline
\end{tabular}

The pre-2016 reforms to incapacity benefits - these days Employment and Support

Allowance - have had their biggest impact on Britain's older industrial areas, where so many incapacity claimants are concentrated.

With the exception of a couple of seaside towns, the list of the 20 hardest-hit authorities is virtually a roll-call of older industrial Britain.

Much of southern England has escaped lightly.

Since the mid-1980s, incapacity benefits have hidden the true scale of worklessness in Britain's weaker local economies, as men and women with health problems or disabilities have claimed incapacity benefits instead of unemployment benefits.

Across Britain as a whole, ESA claimants remain by some margin the largest group out-of-work on benefits and the reforms have resulted in far smaller financial savings to the Treasury than was originally anticipated.

Sources: Sheffield Hallam estimates based on official data 
Employment and Support Allowance - outturn to March 2016

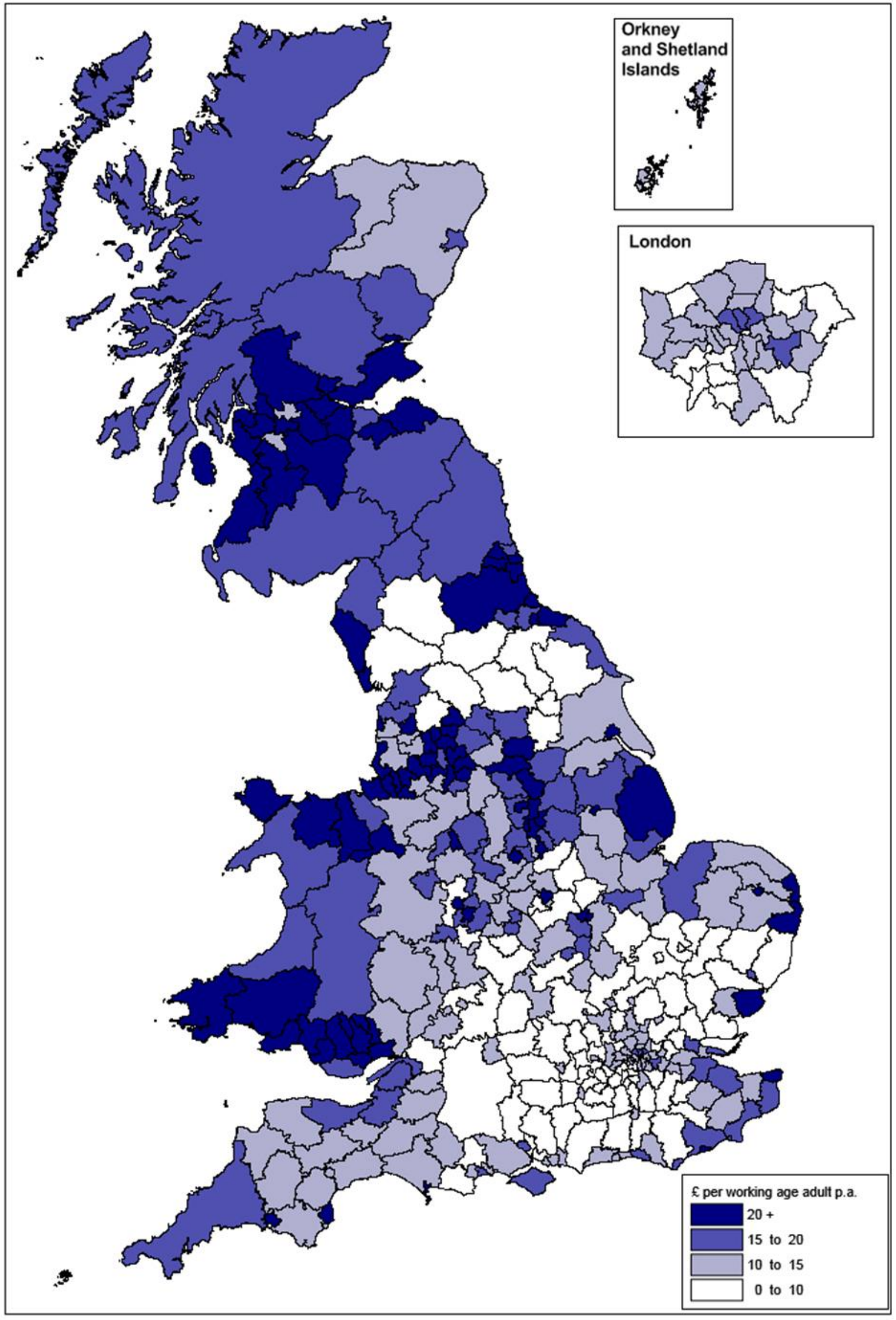

Source: Sheffield Hallam estimates based on official data 


\begin{tabular}{lccc}
\hline & \multicolumn{3}{c}{ Child Benefit } \\
\cline { 2 - 4 } & $\begin{array}{c}\text { No of } \\
\text { households affected }\end{array}$ & $\begin{array}{c}\text { Estimated } \\
\text { Ioss } \\
\mathbf{E m ~ p . a . ~}\end{array}$ & $\begin{array}{c}\text { Loss per } \\
\text { working age adult } \\
\mathbf{E} \text { p.a. }\end{array}$ \\
\hline London & $1,040,000$ & 480 & 82 \\
South East & $1,060,000$ & 450 & 80 \\
East & 730,000 & 300 & 80 \\
North West & 900,000 & 340 & 75 \\
West Midlands & 710,000 & 270 & 75 \\
East Midlands & 560,000 & 220 & 74 \\
Yorkshire \& Humber & 660,000 & 250 & 73 \\
North East & 320,000 & 120 & 72 \\
Wales & 370,000 & 140 & 72 \\
South West & 620,000 & 240 & 71 \\
Scotland & 620,000 & 240 & 69 \\
\hline Great Britain & $\mathbf{7 , 6 0 0 , 0 0 0}$ & 3,025 & $\mathbf{7 6}$ \\
\hline
\end{tabular}

\begin{tabular}{rlc}
\hline WORST AFFECTED & $\begin{array}{c}\text { Loss per } \\
\text { working } \\
\text { 20 LOCAL AUTHOIt } \\
\text { E p.a. }\end{array}$ \\
\hline 1. & Elmbridge & 105 \\
2. & St Albans & 105 \\
3. & Hart & 102 \\
4. & Richmond upon Thames & 101 \\
5. & Barking and Dagenham & 99 \\
6. & Bromley & 98 \\
7. & Windsor and Maidenhead & 97 \\
8. & Wokingham & 96 \\
9. & Surrey Heath & 96 \\
10. & Broxbourne & 96 \\
11. & Chiltern & 95 \\
12. & Reigate and Banstead & 95 \\
13. & Bexley & 95 \\
14. & Spelthorne & 92 \\
15. & Enfield & 92 \\
16. & Three Rivers & 92 \\
17. & Waverley & 92 \\
18. & South Buckinghamshire & 92 \\
19. & Croydon & 92 \\
20. & North Hertfordshire & 91 \\
\hline
\end{tabular}

The cuts to Child Benefit have had a more even impact across Britain than most of the welfare reforms - few places are more than a quarter above or below the national average.

This is partly because the three-year freeze in Child Benefit rates affected all claimants and most places have substantial numbers of children - and partly because the withdrawal of Child Benefit from households with a higher earner affected some household in most places.

The biggest impacts have been in the places where there are substantial numbers of children and a high proportion of higher earners. London's commuter belt, including a number of outer London boroughs, has been hit hardest. 


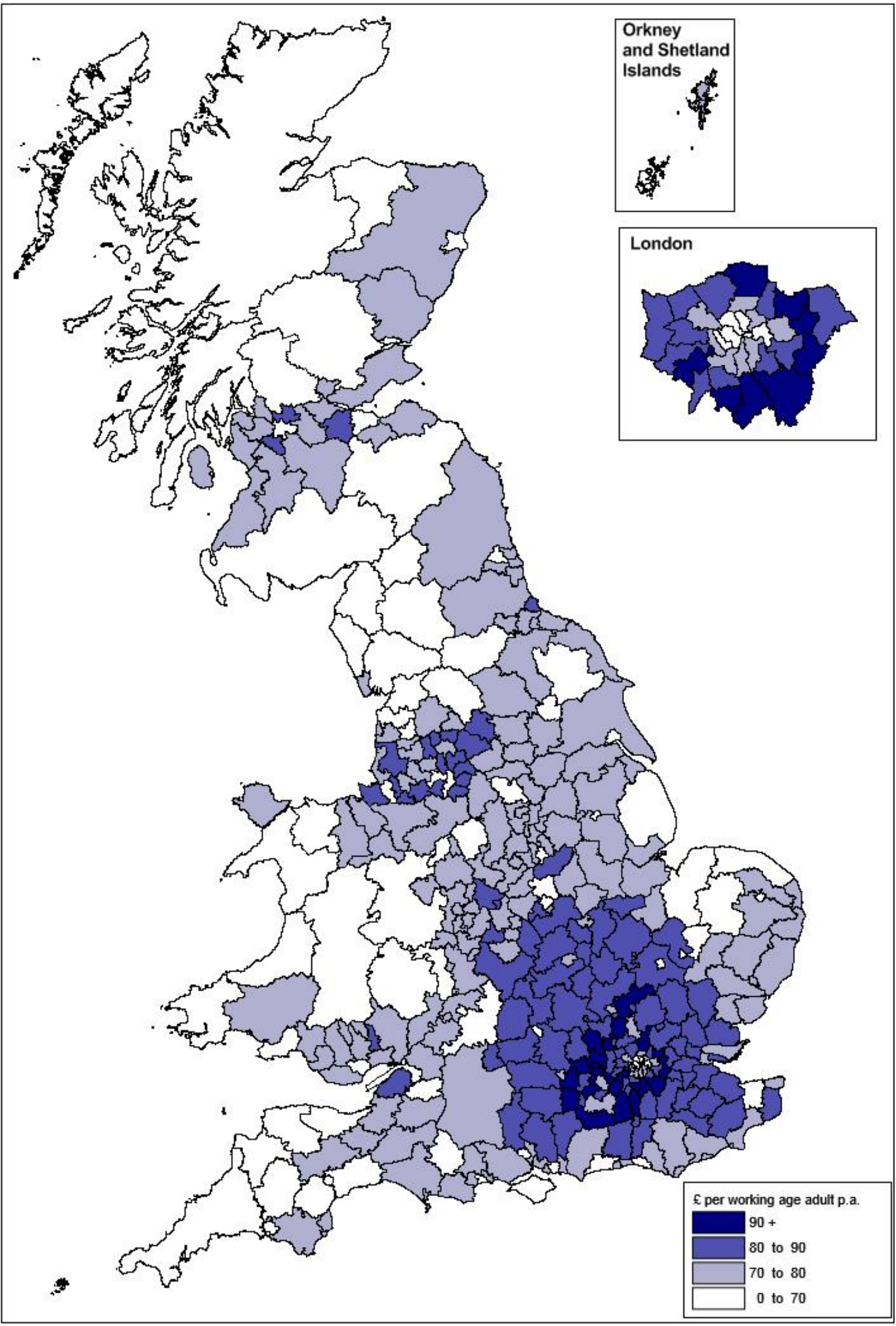

Source: Sheffield Hallam estimates based on official data 


\begin{tabular}{lccc}
\hline & \multicolumn{3}{c}{ Tax Credits } \\
\cline { 2 - 4 } & $\begin{array}{c}\text { No of } \\
\text { households affected }\end{array}$ & $\begin{array}{c}\text { Estimated } \\
\text { Ioss } \\
\text { Em p.a. }\end{array}$ & $\begin{array}{c}\text { Loss per } \\
\text { working age adult } \\
\text { \& p.a. }\end{array}$ \\
\hline North West & 570,000 & 560 & 124 \\
North East & 210,000 & 200 & 122 \\
Yorkshire \& Humber & 420,000 & 410 & 121 \\
West Midlands & 440,000 & 430 & 121 \\
Wales & 240,000 & 230 & 120 \\
East Midlands & 330,000 & 320 & 111 \\
London & 600,000 & 580 & 100 \\
South West & 340,000 & 330 & 98 \\
Scotland & 350,000 & 340 & 97 \\
East & 360,000 & 350 & 94 \\
South East & 470,000 & 460 & 83 \\
\hline Great Britain & $\mathbf{4 , 4 0 0 , 0 0 0}$ & $\mathbf{4 , 2 1 0}$ & $\mathbf{1 0 6}$ \\
\hline
\end{tabular}

\begin{tabular}{rlc}
\hline WORST AFFECTED & $\begin{array}{l}\text { Loss per } \\
\text { working } \\
\text { age adult } \\
\text { 20 } \text { p.a. }\end{array}$ \\
\hline 1. & Blackpool & 176 \\
2. & Blackburn with Darwen & 173 \\
3. & Barking and Dagenham & 169 \\
4. & Peterborough & 166 \\
5. & Bradford & 165 \\
6. & Burnley & 163 \\
7. & Knowsley & 162 \\
8. & Sandwell & 161 \\
9. & Oldham & 161 \\
10. & Hull & 160 \\
11. & Pendle & 160 \\
12. & Thanet & 159 \\
13. & Middlesbrough & 158 \\
14. & Leicester & 158 \\
15. & Boston & 155 \\
16. & Birmingham & 155 \\
17. & Hyndburn & 154 \\
18. & Rochdale & 154 \\
19. & Corby & 152 \\
20. & Stoke-on-Trent & 129 \\
\hline Sources: Sheffield Hallam estimates based on official data
\end{tabular}

Tax Credits - Child Tax Credit and Working Tax Credit - are paid to lower and middleincome families, so the impact of reductions in eligibility and payment rates is felt most in the places where less well-off people live.

The list of local authorities most affected by the pre-2015 changes comprises a combination of urban and rural areas with relatively low wages and in some cases large numbers of children.

London's commuter belt and a number of more prosperous rural areas have been affected less.

At the regional scale, the North of England has lost more than the South, but overall the differences across Britain are less pronounced than for some of the other welfare reforms. 


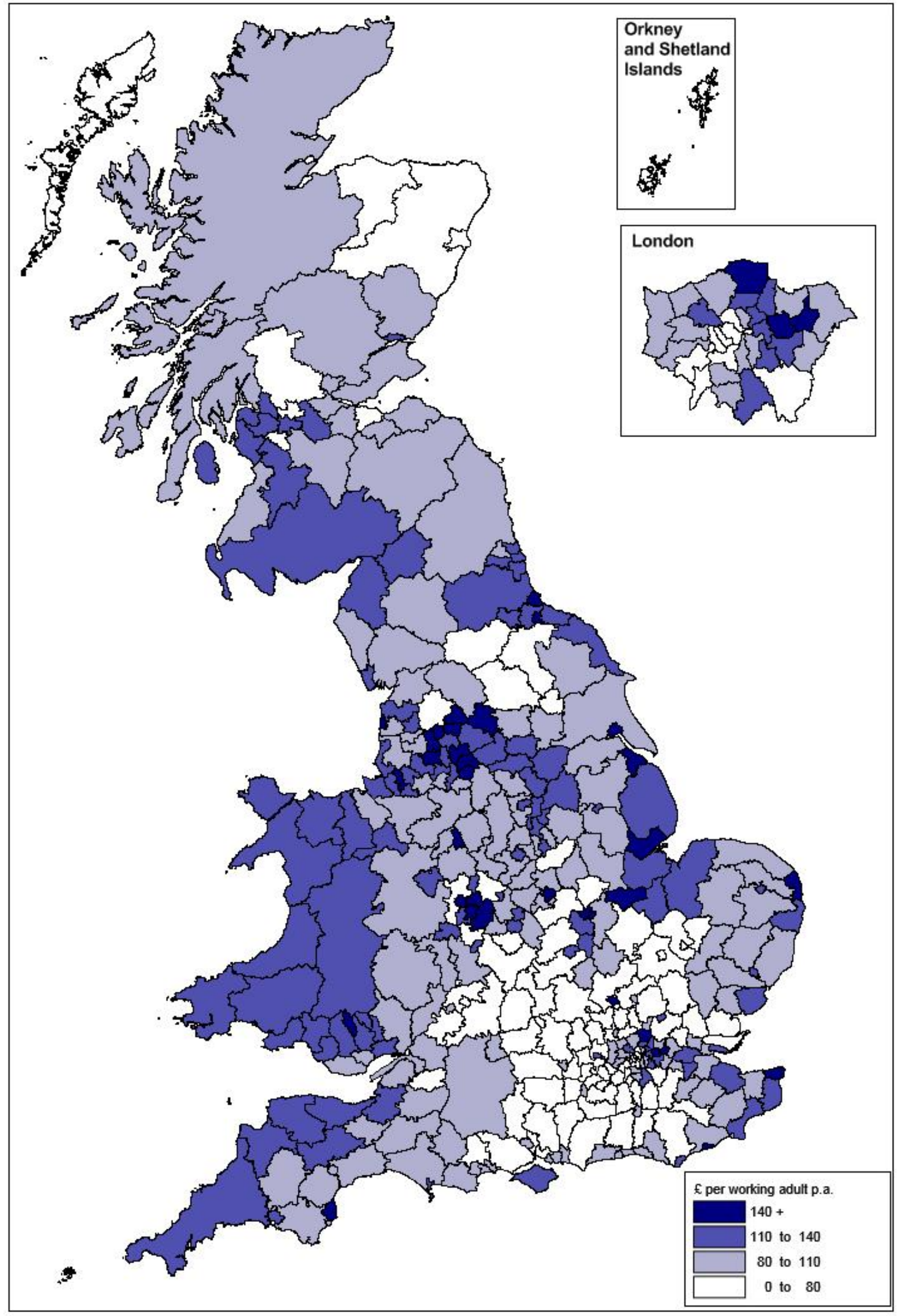

Source: Sheffield Hallam estimates based on official data 


\begin{tabular}{lccc}
\hline & \multicolumn{3}{c}{ 1 per cent uprating } \\
\cline { 2 - 4 } & $\begin{array}{c}\text { No of } \\
\text { households affected }\end{array}$ & $\begin{array}{c}\text { Estimated } \\
\text { Ioss } \\
\text { Em p.a. }\end{array}$ & $\begin{array}{c}\text { Loss per } \\
\text { working age adult } \\
\text { 乏 p.a. }\end{array}$ \\
\hline North East & 380,000 & 140 & 81 \\
North West & $1,020,000$ & 360 & 80 \\
Wales & 430,000 & 150 & 78 \\
Yorkshire and the Humber & 730,000 & 250 & 74 \\
West Midlands & 770,000 & 260 & 73 \\
London & $1,090,000$ & 410 & 71 \\
East Midlands & 580,000 & 190 & 66 \\
Scotland & 700,000 & 230 & 66 \\
South West & 610,000 & 210 & 62 \\
East & 690,000 & 210 & 57 \\
South East & 940,000 & 290 & 53 \\
\hline Great Britain & $\mathbf{7 , 9 0 0 , 0 0 0}$ & $\mathbf{2 , 7 0 0}$ & $\mathbf{6 8}$ \\
\hline
\end{tabular}

\begin{tabular}{clc}
\hline WORST AFFECTED & $\begin{array}{c}\text { Loss per } \\
\text { working } \\
\text { age adult } \\
\text { 20 LOC.a. }\end{array}$ \\
\hline 1. & Blackpool & 137 \\
2. & Hastings & 110 \\
3. & Knowsley & 110 \\
4. & Thanet & 108 \\
5. & Torbay & 107 \\
6. & Middlesbrough & 107 \\
7. & Burnley & 107 \\
8. & Enfield & 105 \\
9. & Hull & 103 \\
10. & Barking and Dagenham & 103 \\
11. & Hartlepool & 103 \\
12. & Blackburn with Darwen & 101 \\
13. & Hyndburn & 100 \\
14. & Blaenau Gwent & 100 \\
15. & Merthyr Tydfil & 99 \\
16. & Liverpool & 98 \\
17. & Great Yarmouth & 97 \\
18. & Rochdale & 96 \\
19. & North East Lincolnshire & 95 \\
20. & Tendring & 95 \\
\hline Sources: Sheffield Hallam estimates based on official data
\end{tabular}

The 1 per cent up-rating of a wide range of working-age benefits inevitably impacted most where these benefits are claimed by the largest number of people.

This means that places with high numbers out-of-work on benefits or with large numbers claiming Housing Benefit or in-work benefits were the ones hit hardest.

In practice, therefore, the 1 per cent up-rating reinforced the local and regional impact of a range of other welfare reforms.

Britain's older industrial areas, a number of seaside towns and some London boroughs faced the greatest impacts.

Once more, large parts of southern and eastern England outside London escaped with the smallest financial losses. 


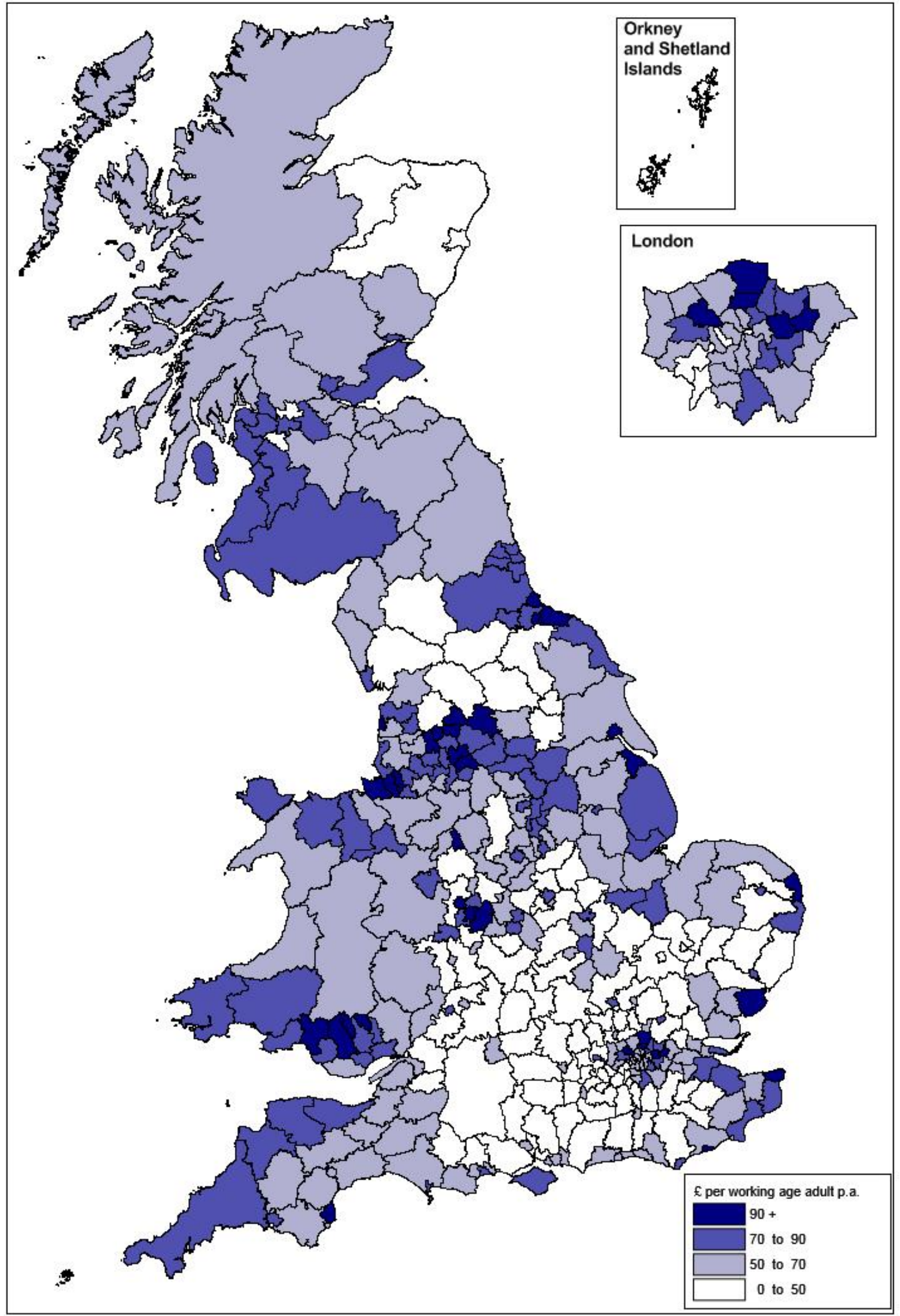

Source: Sheffield Hallam estimates based on official data 


\begin{tabular}{lccc}
\hline & \multicolumn{2}{c}{ Universal Credit tapers and thresholds } \\
\cline { 2 - 4 } & $\begin{array}{c}\text { No of } \\
\text { households affected }\end{array}$ & $\begin{array}{c}\text { Estimated } \\
\text { loss } \\
\mathbf{E m ~ p . a . ~}\end{array}$ & $\begin{array}{c}\text { Loss per } \\
\text { working age adult } \\
\mathbf{E ~ p . a . ~}\end{array}$ \\
\hline Yorkshire \& Humber & 300,000 & 320 & 95 \\
North West & 400,000 & 430 & 94 \\
West Midlands & 310,000 & 330 & 92 \\
North East & 140,000 & 150 & 90 \\
Wales & 160,000 & 170 & 89 \\
East Midlands & 240,000 & 260 & 88 \\
South West & 250,000 & 260 & 79 \\
Scotland & 240,000 & 260 & 74 \\
East & 260,000 & 270 & 73 \\
London & 400,000 & 430 & 64 \\
South East & 330,000 & 350 & $\mathbf{8 1}$ \\
\hline Great Britain & $\mathbf{3 , 0 0 0 , 0 0 0}$ & $\mathbf{3 , 2 2 0}$ & \\
\hline
\end{tabular}

\begin{tabular}{|c|c|c|}
\hline $\begin{array}{l}\text { WORST AFFECTED } \\
20 \text { LOCAL AUTHORITIES }\end{array}$ & $\begin{array}{l}\text { Loss per } \\
\text { working } \\
\text { age adult } \\
\text { £ p.a. }\end{array}$ & \multirow{3}{*}{$\begin{array}{l}\text { Universal Credit is gradually replacing a } \\
\text { range of means-tested working age benefits. } \\
\text { The new tapers and thresholds increase the } \\
\text { amounts withdrawn as income rises. The } \\
\text { effect is to reduce payments in places where } \\
\text { in-work claimants are numerous. }\end{array}$} \\
\hline 1. Boston & 139 & \\
\hline 2. Blackburn with Darwen & 136 & \\
\hline 3. Bradford & 135 & \multirow{5}{*}{$\begin{array}{l}\text { The list of local authorities most affected by } \\
\text { these changes comprises a combination of } \\
\text { urban and rural areas with relatively low } \\
\text { wages and in some cases large numbers of } \\
\text { children. }\end{array}$} \\
\hline 4. Pendle & 131 & \\
\hline 5. Peterborough & 131 & \\
\hline 6. Leicester & 130 & \\
\hline 7. Oldham & 128 & \\
\hline 8. Blackpool & 128 & \multirow{3}{*}{$\begin{array}{l}\text { London's commuter belt and a number of } \\
\text { more prosperous rural areas are affected } \\
\text { less. }\end{array}$} \\
\hline 9. Barking and Dagenham & 125 & \\
\hline 10. Burnley & 123 & \\
\hline 11. Thanet & 122 & \multirow{10}{*}{$\begin{array}{l}\text { Similar tapers and thresholds currently affect } \\
\text { Tax Credits. The change to the new rates } \\
\text { occurs as claimants move across onto } \\
\text { Universal Credit. }\end{array}$} \\
\hline 12. Hyndburn & 122 & \\
\hline 13. Corby & 121 & \\
\hline 14. Sandwell & 121 & \\
\hline 15. West Somerset & 119 & \\
\hline 16. Rochdale & 118 & \\
\hline 17. Hull & 118 & \\
\hline 18. Luton & 117 & \\
\hline 19. Bolton & 115 & \\
\hline 20. Torridge & 114 & \\
\hline
\end{tabular}

Sources: Sheffield Hallam estimates based on New Policy Institute data 


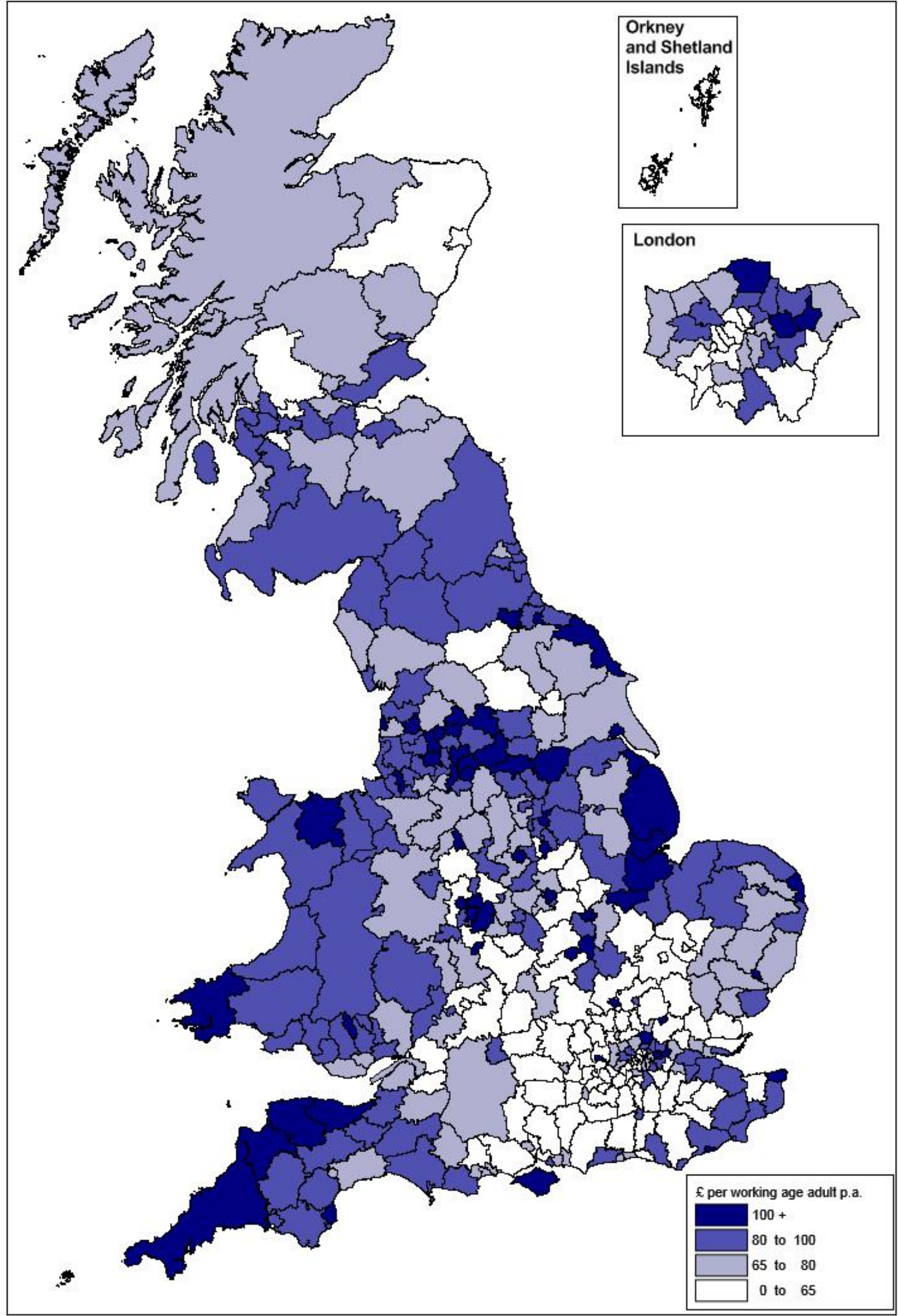

Source: Sheffield Hallam estimates based on New Policy Institute data 


\begin{tabular}{lccc}
\hline & \multicolumn{3}{c}{ Tax Credits (new reforms) } \\
\cline { 2 - 4 } & $\begin{array}{c}\text { No of } \\
\text { households affected }\end{array}$ & $\begin{array}{c}\text { Estimated } \\
\text { loss } \\
\text { Em p.a. }\end{array}$ & $\begin{array}{c}\text { Loss per } \\
\text { working age adult } \\
\mathbf{E} \text { p.a. }\end{array}$ \\
\hline West Midlands & 220,000 & 240 & 68 \\
Yorkshire \& Humber & 200,000 & 210 & 63 \\
North West & 270,000 & 280 & 61 \\
London & 300,000 & 340 & 58 \\
East Midlands & 160,000 & 160 & 56 \\
Wales & 110,000 & 110 & 55 \\
North East & 90,000 & 90 & 52 \\
East & 170,000 & 180 & 48 \\
South West & 150,000 & 150 & 46 \\
South East & 220,000 & 230 & 41 \\
Scotland & 150,000 & 140 & 40 \\
\hline Great Britain & $\mathbf{2 , 0 0 0 , 0 0 0}$ & $\mathbf{2 , 1 1 5}$ & $\mathbf{5 3}$ \\
\hline
\end{tabular}

\begin{tabular}{rlc}
\hline WORST AFFECTED & $\begin{array}{c}\text { Loss per } \\
\text { working } \\
\text { age adult } \\
\text { 20 L.a. }\end{array}$ \\
\hline 1. & Blackburn with Darwen & 131 \\
2. & Bradford & 130 \\
3. & Barking and Dagenham & 126 \\
4. & Newham & 124 \\
5. & Luton & 114 \\
6. & Birmingham & 111 \\
7. & Leicester & 111 \\
8. & Oldham & 109 \\
9. & Pendle & 100 \\
10. & Slough & 98 \\
11. & Peterborough & 98 \\
12. & Sandwell & 98 \\
13. & Rochdale & 91 \\
14. & Enfield & 90 \\
15. & Walsall & 88 \\
16. & Hyndburn & 87 \\
17. & Middlesbrough & 84 \\
18. & Burnley & 84 \\
19. & Bolton & 82 \\
20. & Brent & 80 \\
\hline
\end{tabular}

Almost two-thirds of the anticipated financial loss arising from the post-2015 reforms to Tax Credits is expected to fall on large families, who lose entitlement for the third and subsequent child born after March 2017.

The places likely to lose most from the new reforms to Tax Credits are therefore those where there are normally substantial numbers of large families. These include several towns where there is a large population of Asian ethnic origin.

Where earnings tend to be higher and entitlement to Tax Credits is lower - across substantial parts of the suburban south for example - the new reforms to Tax Credits can be expected to have a smaller impact.

If the reforms to Tax Credits trigger significant behavioural change - smaller families in particular - some of the financial loss will not occur. 


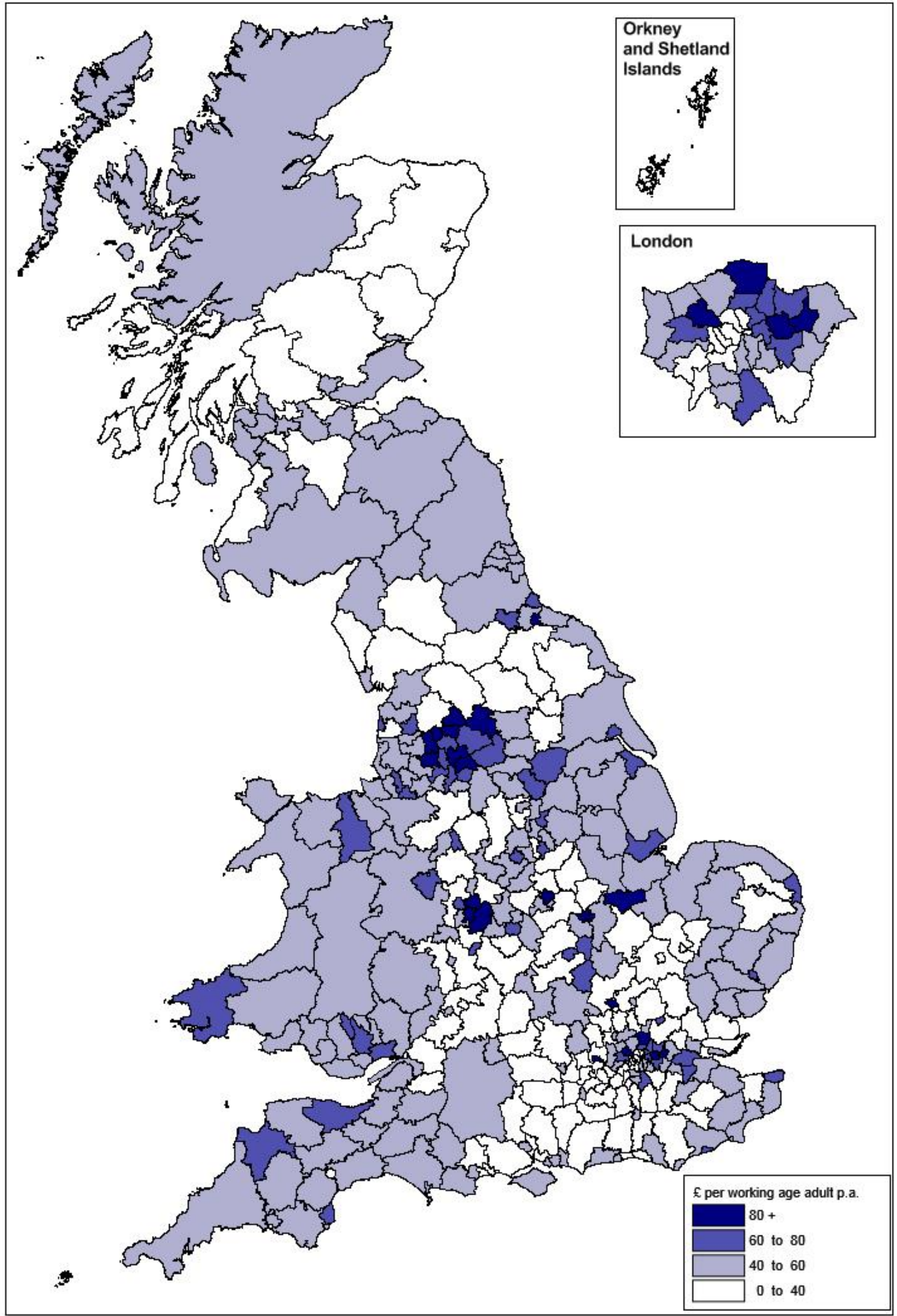

Source: Sheffield Hallam estimates based on official data 


\begin{tabular}{lccc}
\hline & \multicolumn{3}{c}{ Mortgage interest support } \\
\cline { 2 - 4 } & $\begin{array}{c}\text { No of } \\
\text { households affected }\end{array}$ & $\begin{array}{c}\text { Estimated } \\
\text { loss } \\
\text { Em p.a. }\end{array}$ & $\begin{array}{c}\text { Loss per } \\
\text { working age adult } \\
\text { \& p.a. }\end{array}$ \\
\hline Wales & 12,000 & 20 & 9 \\
North East & 10,000 & 15 & 9 \\
North West & 25,000 & 35 & 8 \\
West Midlands & 17,000 & 25 & 7 \\
Scotland & 17,000 & 25 & 7 \\
Yorkshire \& Humber & 17,000 & 25 & 7 \\
South West & 13,000 & 20 & 6 \\
East Midlands & 12,000 & 20 & 6 \\
East & 13,000 & 20 & 5 \\
South East & 18,000 & 25 & 5 \\
London & 17,000 & 25 & $\mathbf{6}$ \\
\hline Great Britain & 170,000 & 255 & 4 \\
\hline
\end{tabular}

\begin{tabular}{rlc}
\hline WORST AFFECTED & $\begin{array}{c}\text { Loss per } \\
\text { working } \\
\text { age adult } \\
\text { 20 L.a. }\end{array}$ \\
\hline 1. & Blackpool & 13 \\
2. & Blaenau Gwent & 13 \\
3. & Rhondda Cynon Taf & 13 \\
4. & Knowsley & 13 \\
5. & Merthyr Tydfil & 12 \\
6. & Neath Port Talbot & 12 \\
7. & Caerphilly & 11 \\
8. & Barrow-in -Furness & 11 \\
9. & Inverclyde & 11 \\
10. & Bridgend & 11 \\
11. & Burnley & 11 \\
12. & Tendring & 11 \\
13. & Middlesbrough & 11 \\
14. & North Ayrshire & 11 \\
15. & St Helens & 11 \\
16. & Hartlepool & 11 \\
17. & Wirral & 11 \\
18. & Blackburn with Darwen & 10 \\
19. & Redcar and Cleveland & 10 \\
20. & Hyndburn & 10 \\
\hline
\end{tabular}

Changing mortgage interest support from a welfare payment into a loan impacts most in the places where there is a high out-ofwork benefit claimant rate and where owneroccupied housing also makes up a large proportion of the stock.

The places most affected tend to be older industrial areas but also a handful of less prosperous seaside towns.

Large parts of southern England, where worklessness is low, are little affected by this reform.

London escapes much of the impact because so much of its housing is rented rather than owner-occupied. 


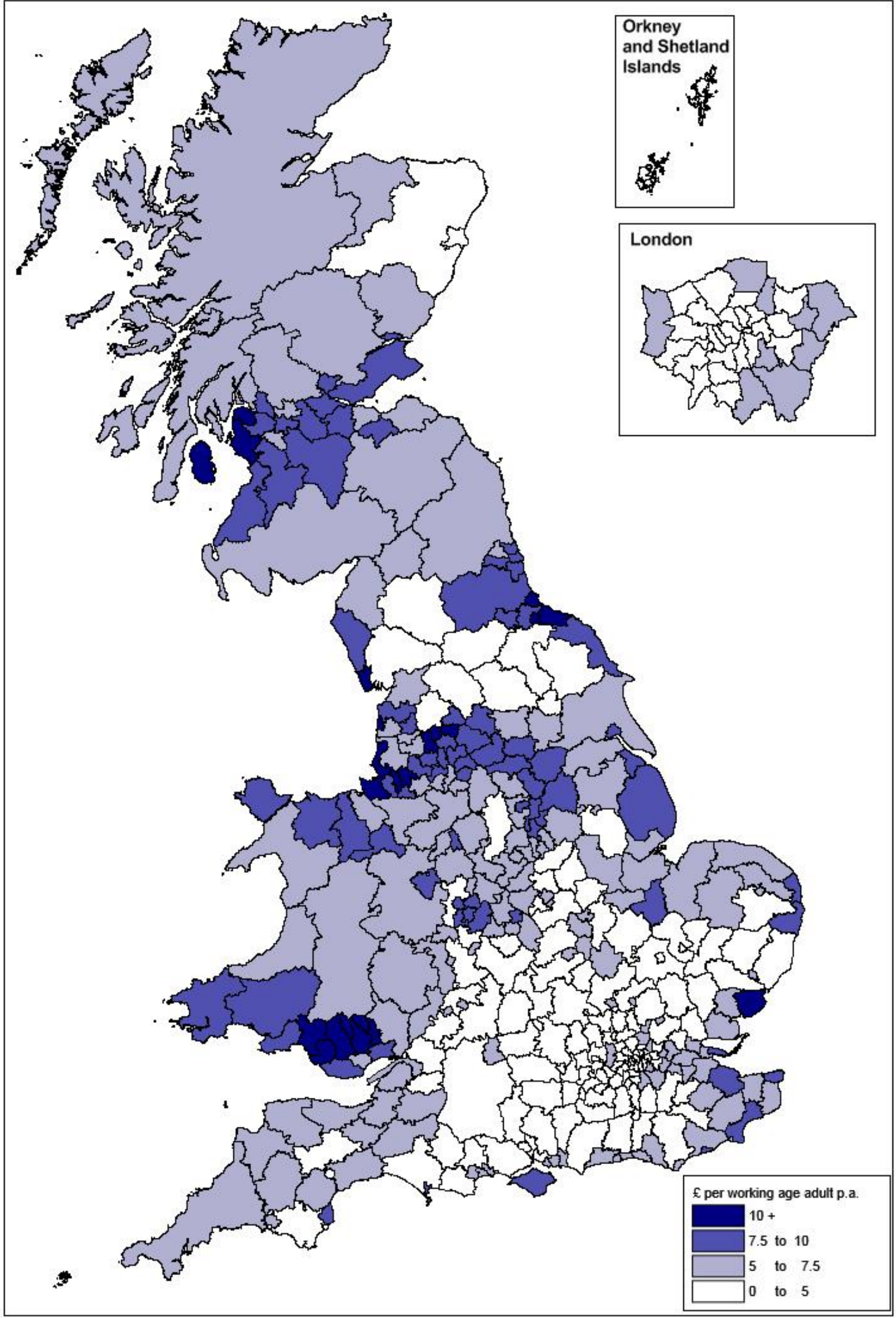

Source: Sheffield Hallam estimates based on official data 


\begin{tabular}{lccc}
\hline & \multicolumn{3}{c}{ 'Pay to stay' } \\
\cline { 2 - 4 } & $\begin{array}{c}\text { No of } \\
\text { households affected }\end{array}$ & $\begin{array}{c}\text { Estimated } \\
\text { loss } \\
\text { Em p.a. }\end{array}$ & $\begin{array}{c}\text { Loss per } \\
\text { working age adult } \\
\text { 乏 p.a. }\end{array}$ \\
\hline London & 26,000 & 80 & 14 \\
Yorkshire \& Humber & 20,000 & 25 & 8 \\
West Midlands & 17,000 & 25 & 7 \\
East Midlands & 15,000 & 20 & 7 \\
East & 13,000 & 25 & 6 \\
North East & 8,000 & 10 & 6 \\
South East & 14,000 & 30 & 5 \\
South West & 8,000 & 15 & 2 \\
North West & 7,000 & 10 & 0 \\
Wales & 0 & 0 & 0 \\
Scotland & 0 & 0 & $\mathbf{6}$ \\
\hline Great Britain & $\mathbf{1 3 0 , 0 0 0}$ & $\mathbf{2 4 0}$ & 4 \\
\hline
\end{tabular}

\begin{tabular}{|c|c|}
\hline $\begin{array}{l}\text { WORST AFFECTED } \\
20 \text { LOCAL AUTHORITIES }\end{array}$ & $\begin{array}{c}\text { Loss per } \\
\text { working } \\
\text { age adult } \\
£ \text { p.a. }\end{array}$ \\
\hline 1. Islington & 34 \\
\hline 2. Camden & 32 \\
\hline 3. Southwark & 31 \\
\hline 4. Harlow & 29 \\
\hline 5. Hackney & 29 \\
\hline 6. Barking and Dagenham & 25 \\
\hline 7. Stevenage & 22 \\
\hline 8. Welwyn Hatfield & 21 \\
\hline 9. South Tyneside & 21 \\
\hline 10. Hammersmith and Fulham & 21 \\
\hline 11. Dacorum & 20 \\
\hline 12. Crawley & 20 \\
\hline 13. Greenwich & 19 \\
\hline 14. Norwich & 19 \\
\hline 15. Lambeth & 19 \\
\hline 16. Sandwell & 18 \\
\hline 17. Westminster & 18 \\
\hline 18. Gateshead & 18 \\
\hline 19. Wolverhampton & 17 \\
\hline 20. Wandsworth & 17 \\
\hline
\end{tabular}

'Pay to stay' - the new requirement on higher income local authority tenants to pay market rents - will impact most where the stock of council housing remains large and where private sector rents are well ahead of those in the social sector.

A number of inner London boroughs face the largest impacts, even though the income threshold is set higher in London than elsewhere. With a substantial stock of council housing, large numbers of households are likely to be affected and they each face larger losses than elsewhere because market rents in inner London are so high.

If housing associations decide to use their discretionary power to apply 'pay to stay' the losses will be larger than those shown here, especially in the places where most or all of the council housing has undergone stock transfer,

This reform does not apply to Scotland and Wales, where the management of the social rented sector is a devolved matter. 


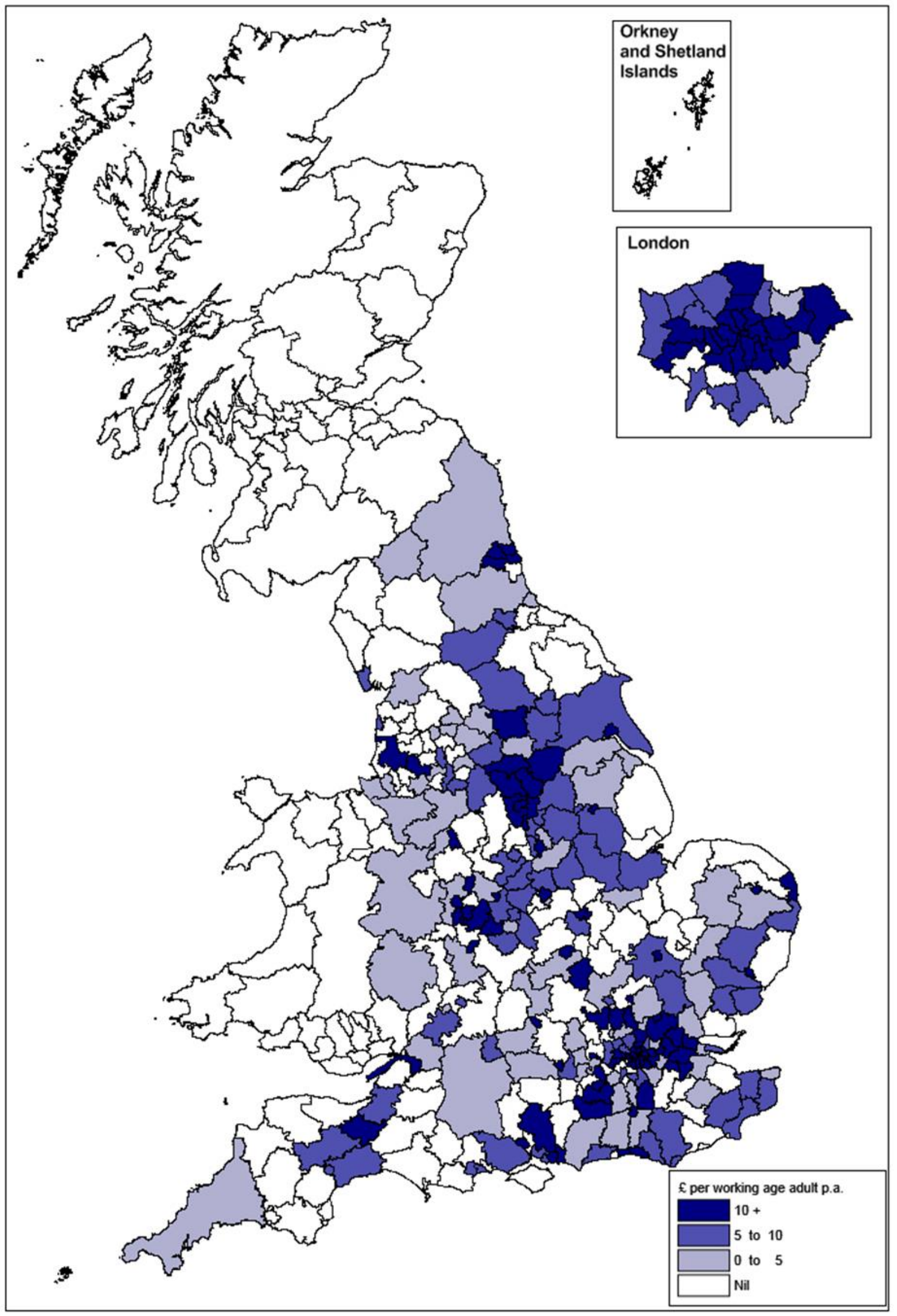

Sheffield Hallam estimates based on official data 


\begin{tabular}{lccc}
\hline & \multicolumn{3}{c}{ LHA cap in social rented sector } \\
\cline { 2 - 4 } & $\begin{array}{c}\text { No of } \\
\text { households affected }\end{array}$ & $\begin{array}{c}\text { Estimated } \\
\text { Ioss } \\
\mathbf{E m ~ p . a . ~}\end{array}$ & $\begin{array}{c}\text { Loss per } \\
\text { working age adult } \\
\mathbf{E} \text { p.a. }\end{array}$ \\
\hline North East & 17,000 & 15 & 8 \\
Scotland & 33,000 & 25 & 7 \\
West Midlands & 30,000 & 20 & 6 \\
North West & 37,000 & 30 & 6 \\
London & 47,000 & 35 & 6 \\
Wales & 15,000 & 10 & 6 \\
Yorkshire \& Humber & 27,000 & 20 & 6 \\
East Midlands & 20,000 & 15 & 5 \\
East & 24,000 & 20 & 4 \\
South West & 20,000 & 15 & 4 \\
South East & 30,000 & 20 & $\mathbf{6}$ \\
\hline Great Britain & $\mathbf{3 0 0 , 0 0 0}$ & $\mathbf{2 2 5}$ & \\
\hline
\end{tabular}

\begin{tabular}{|c|c|}
\hline $\begin{array}{l}\text { WORST AFFECTED } \\
20 \text { LOCAL AUTHORITIES }\end{array}$ & $\begin{array}{c}\text { Loss per } \\
\text { working } \\
\text { age adult } \\
£ \text { p.a. }\end{array}$ \\
\hline 1. West Dunbartonshire & 12 \\
\hline 2. Glasgow & 12 \\
\hline 3. South Tyneside & 11 \\
\hline 4. Islington & 11 \\
\hline 5. Norwich & 10 \\
\hline 6. Knowsley & 10 \\
\hline 7. Hull & 10 \\
\hline 8. Dundee & 10 \\
\hline 9. Southwark & 10 \\
\hline 10. Hackney & 10 \\
\hline 11. Tower Hamlets & 10 \\
\hline 12. Middlesbrough & 10 \\
\hline 13. Inverclyde & 9 \\
\hline 14. North Ayrshire & 9 \\
\hline 15. Torfaen & 9 \\
\hline 16. Hartlepool & 9 \\
\hline 17. Blaenau Gwent & 9 \\
\hline 18. Clackmannanshire & 9 \\
\hline 19. Gateshead & 9 \\
\hline 20. Sunderland & 9 \\
\hline
\end{tabular}

Applying the Local Housing Allowance cap in the social rented sector, which aligns Housing Benefit entitlement with the equivalent rate in the private rented sector, has a complex impact.

It impacts most where council and housing association properties are a high proportion of the total housing stock but also where rents in these properties are high relative to the LHA rate.

In practice the areas most affected include a range of older industrial areas in the North and Scotland in particular but also several inner London boroughs.

Large parts of southern and eastern England outside London, where the social housing sector is small, are relatively unaffected by this reform. 


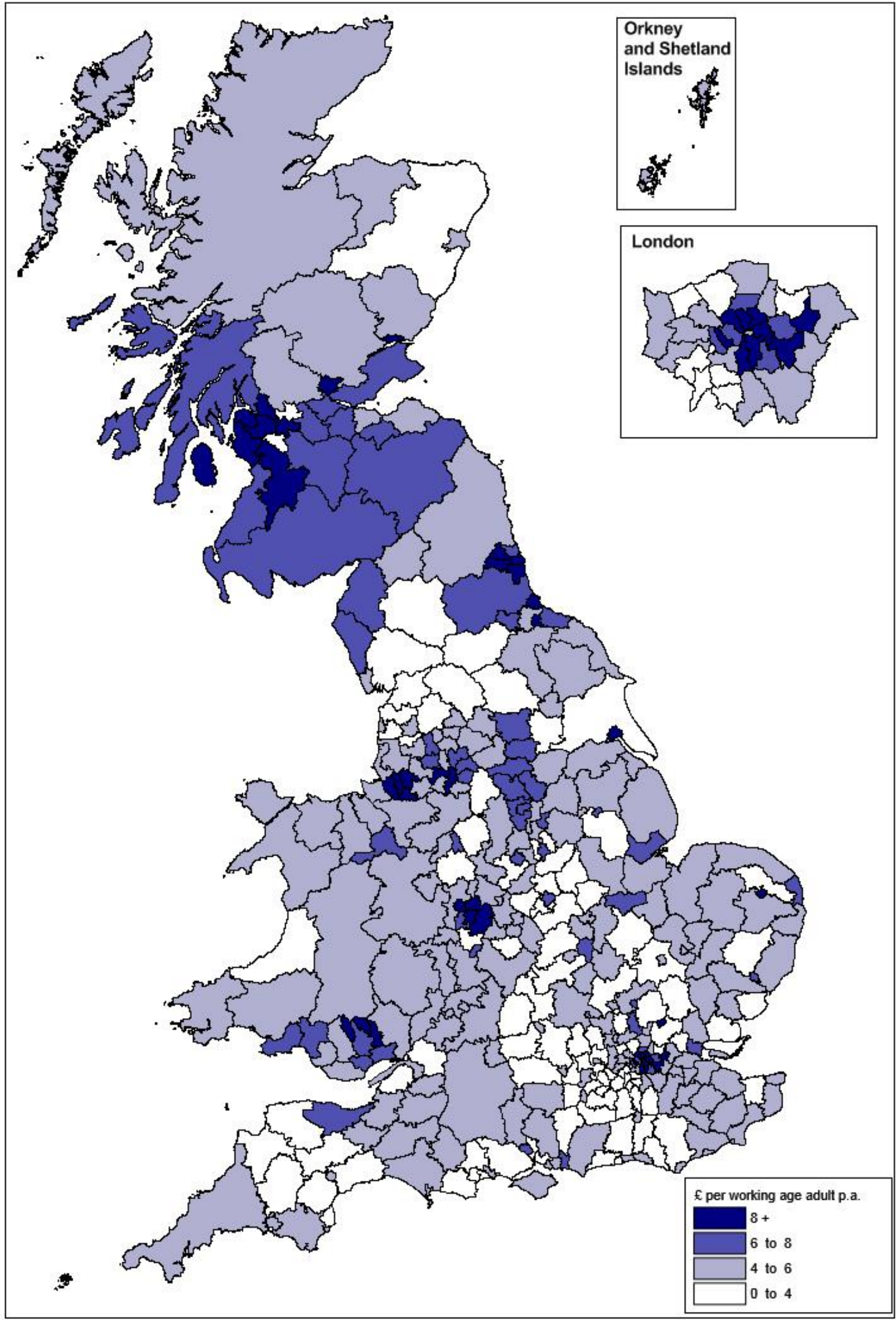

Source: Sheffield Hallam estimates based on official data 


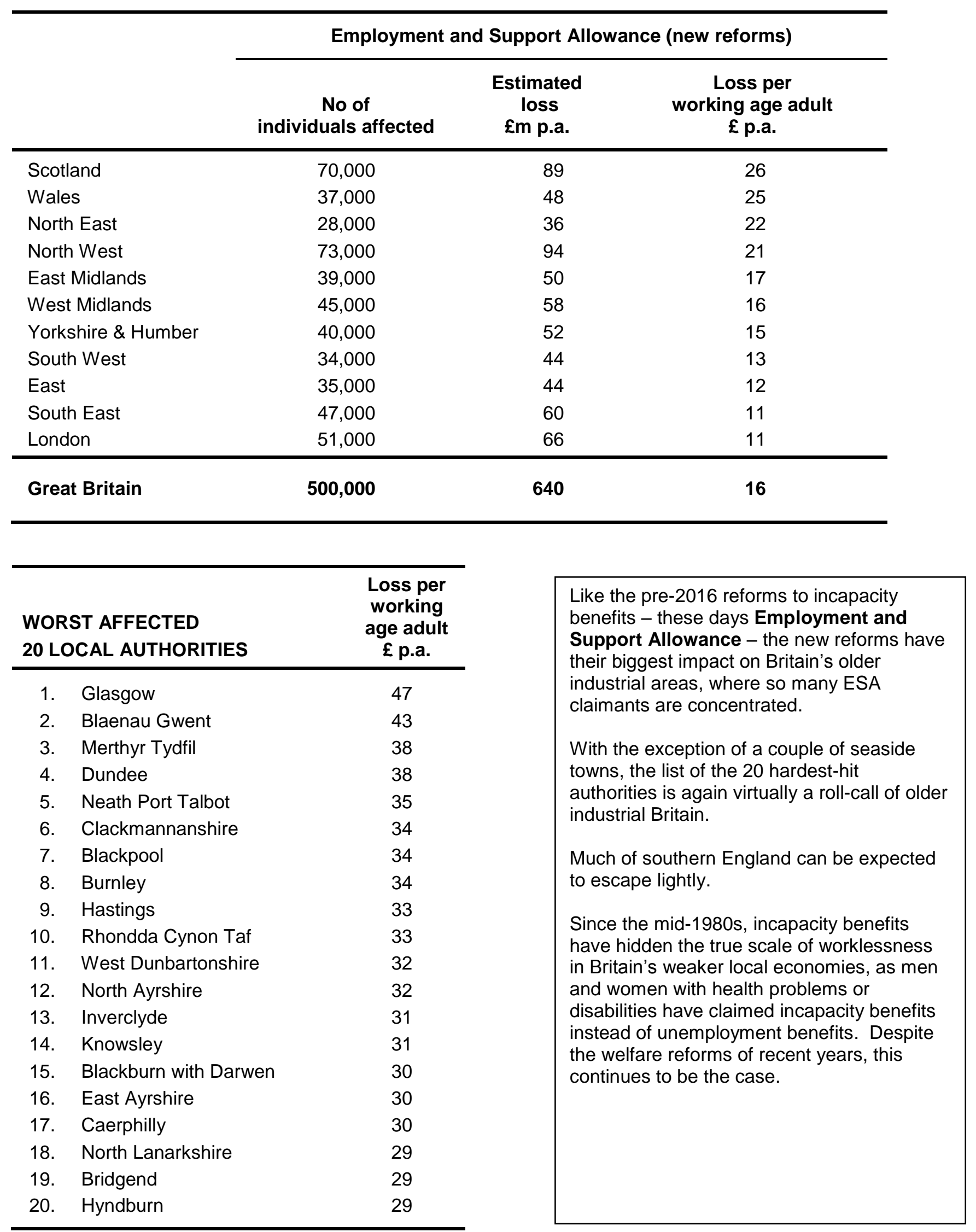

Sources: Sheffield Hallam estimates based on official data 
Employment and Support Allowance (new reforms) - anticipated impact to 2020-21

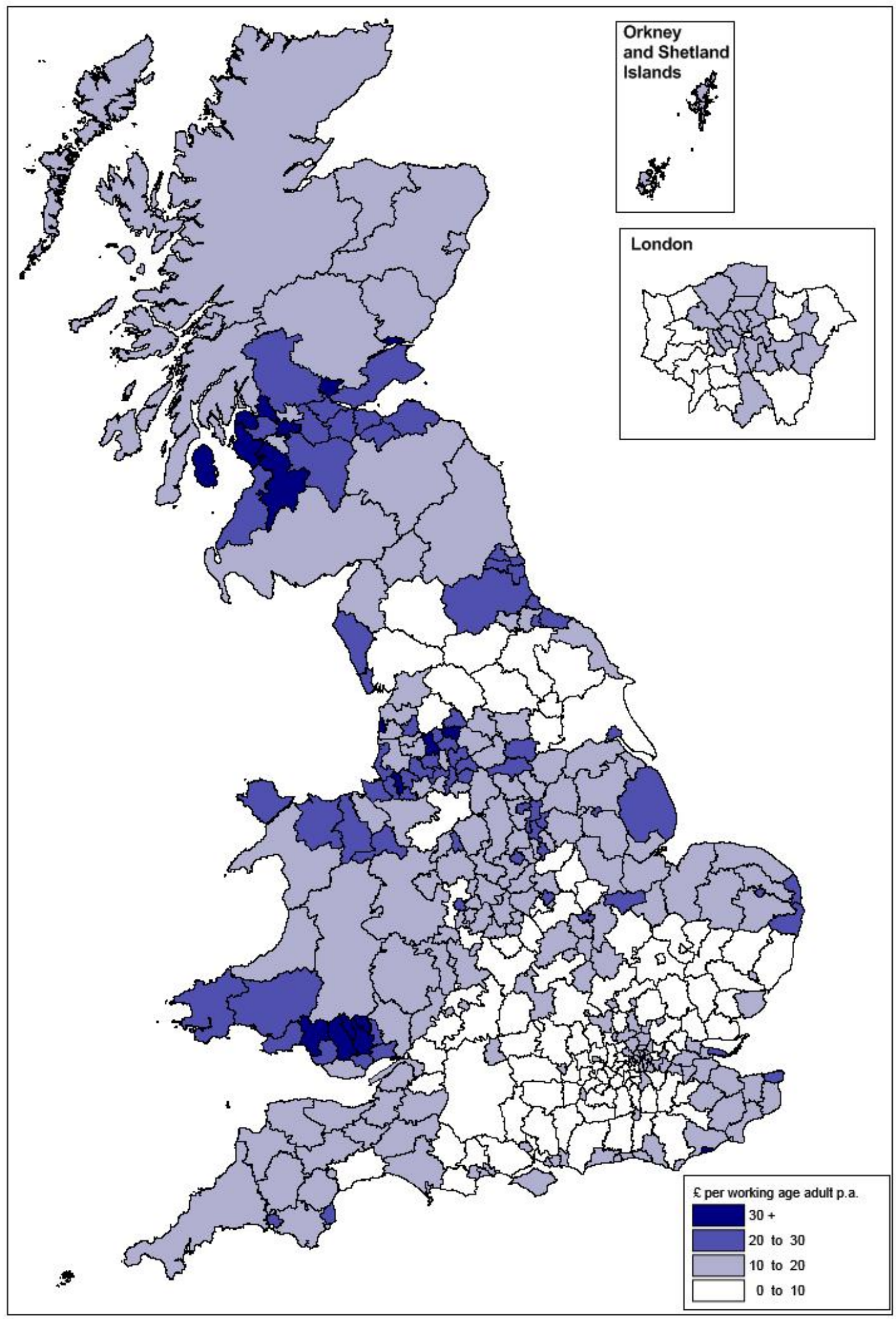

Source: Sheffield Hallam estimates based on official data 


\begin{tabular}{lccc}
\hline \multicolumn{3}{c}{ Benefit Cap (extension) } \\
\cline { 2 - 4 } & $\begin{array}{c}\text { No of } \\
\text { households affected }\end{array}$ & $\begin{array}{c}\text { Estimated } \\
\text { loss } \\
\text { Em p.a. }\end{array}$ & $\begin{array}{c}\text { Loss per } \\
\text { working age adult } \\
\text { £ p.a. }\end{array}$ \\
\hline West Midlands & 21,000 & 55 & 15 \\
North West & 27,000 & 65 & 14 \\
North East & 10,000 & 25 & 14 \\
Wales & 11,000 & 30 & 14 \\
London & 50,000 & 85 & 14 \\
Yorkshire \& Humber & 18,000 & 45 & 13 \\
Scotland & 16,000 & 40 & 11 \\
East Midlands & 13,000 & 30 & 11 \\
East & 15,000 & 40 & 10 \\
South East & 21,000 & 55 & 10 \\
South West & 13,000 & 35 & $\mathbf{1 2}$ \\
\hline Great Britain & $\mathbf{2 1 0 , 0 0 0}$ & 495 & \\
\hline
\end{tabular}

\begin{tabular}{rlc}
\hline WORST AFFECTED & $\begin{array}{l}\text { Loss per } \\
\text { working } \\
\text { age adult } \\
\text { 20 LOCAL }\end{array}$ \\
\hline 1. & Birmingham & 26 \\
2. & Middlesbrough & 24 \\
3. & Blackpool & 24 \\
4. & Blackburn with Darwen & 23 \\
5. & Enfield & 23 \\
6. & Knowsley & 23 \\
7. & Brent & 22 \\
8. & Hastings & 22 \\
9. & Barking and Dagenham & 21 \\
10. & Hartlepool & 21 \\
11. & Sandwell & 21 \\
12. & Wolverhampton & 21 \\
13. & Slough & 20 \\
14. & Luton & 20 \\
15. & Ealing & 20 \\
16. & Tendring & 20 \\
17. & Bradford & 20 \\
18. & Walsall & 20 \\
19. & Manchester & 20 \\
20. & Merthyr Tydfil & 20 \\
\hline Sources: Sheffield Hallam estimates based on official data
\end{tabular}

The new Benefit Cap impacts more widely than the pre-2016 cap, hitting far more households, especially outside London.

The pre-2016 cap was triggered mainly by high Housing Benefit payments (particularly in London) and by large family size. These remain the key, but the new lower level of the cap means they come into play in a wider range of places.

All the existing capped households lose out financially as a result of the lower cap and an estimated 190,000 are added by $2020-21$.

Large numbers of households are affected by the new cap in London, but here the maximum loss is limited to $£ 3,000$ a year. Outside London the maximum loss is $£ 6,000$ a year. The result is that far more places outside London figure among the worst-hit local authorities than was the case with the pre-2016 cap. 


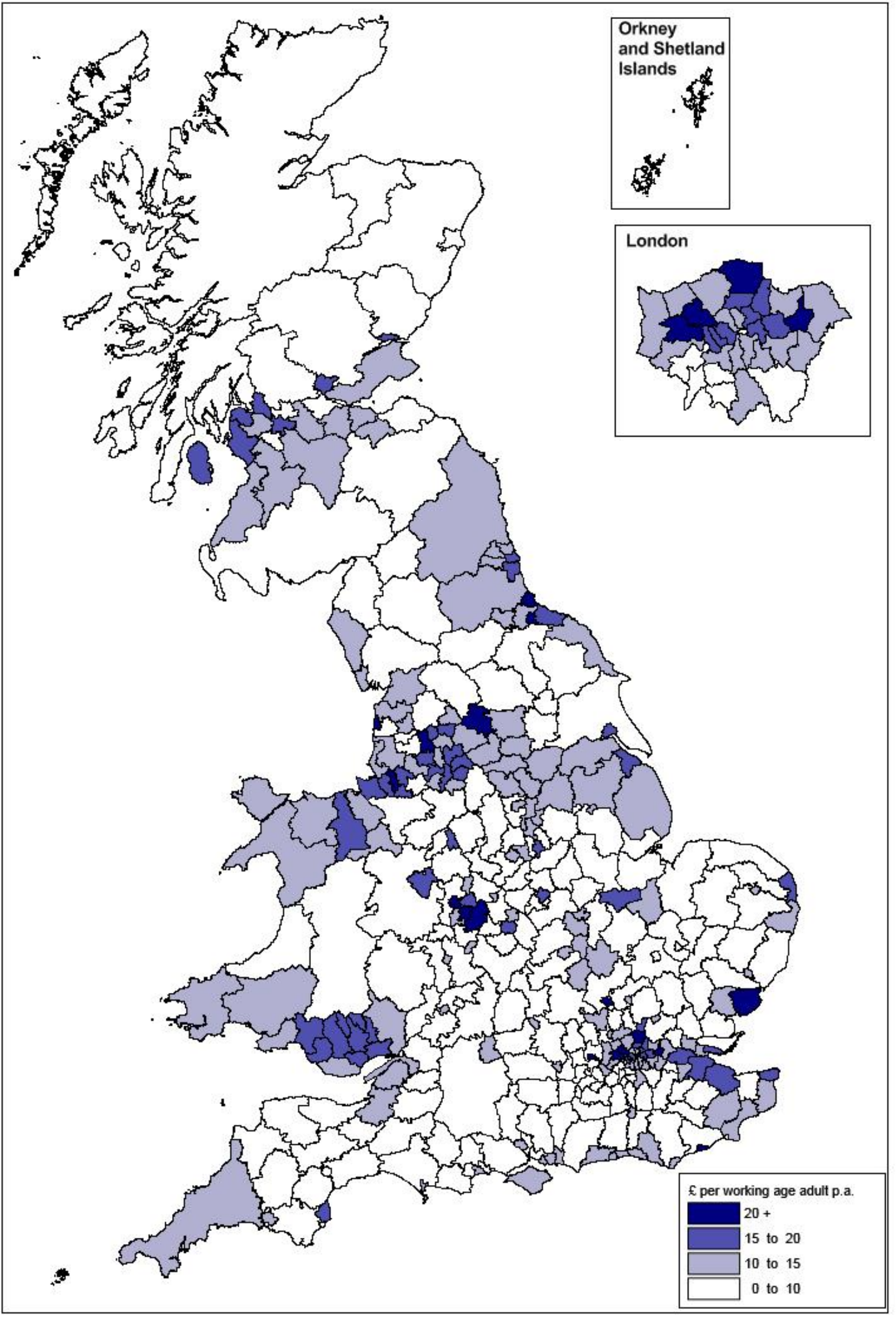

Source: Sheffield Hallam estimates based on official data 


\begin{tabular}{lccc}
\hline & \multicolumn{3}{c}{ Benefit freeze } \\
\cline { 2 - 4 } & $\begin{array}{c}\text { No of } \\
\text { households affected }\end{array}$ & $\begin{array}{c}\text { Estimated } \\
\text { Ioss } \\
\text { Em p.a. }\end{array}$ & $\begin{array}{c}\text { Loss per } \\
\text { working age adult } \\
\text { \& p.a. }\end{array}$ \\
\hline North East & 380,000 & 200 & 119 \\
North West & $1,010,000$ & 520 & 116 \\
Wales & 430,000 & 220 & 115 \\
Yorkshire \& Humber & 720,000 & 380 & 111 \\
West Midlands & 770,000 & 390 & 110 \\
London & $1,080,000$ & 630 & 108 \\
East Midlands & 580,000 & 290 & 98 \\
Scotland & 700,000 & 330 & 96 \\
South West & 620,000 & 300 & 91 \\
East & 690,000 & 320 & 85 \\
South East & 960,000 & 430 & 78 \\
\hline Great Britain & $\mathbf{7 , 9 0 0 , 0 0 0}$ & $\mathbf{4 , 0 1 0}$ & $\mathbf{1 0 1}$ \\
\hline
\end{tabular}

\begin{tabular}{rlc}
\hline WORST AFFECTED & $\begin{array}{c}\text { Loss per } \\
\text { working } \\
\text { 20 LOCAL AUTHOIt } \\
\text { E p.a. }\end{array}$ \\
\hline 1. & Blackpool & 193 \\
2. & Enfield & 167 \\
3. & Barking and Dagenham & 162 \\
4. & Middlesbrough & 161 \\
5. & Thanet & 159 \\
6. & Hastings & 157 \\
7. & Knowsley & 156 \\
8. & Torbay & 154 \\
9. & Burnley & 153 \\
10. & Blackburn with Darwen & 152 \\
11. & Hull & 152 \\
12. & Tendring & 148 \\
13. & Bradford & 147 \\
14. & Birmingham & 146 \\
15. & Sandwell & 146 \\
16. & Hyndburn & 145 \\
17. & Brent & 144 \\
18. & Oldham & 144 \\
19. & Hartlepool & 144 \\
20. & Great Yarmouth & 143 \\
\hline Sources: Sheffield Hallam estimates based on official data
\end{tabular}

Like the 1 per cent limit on the uprating of a wide range of working-age benefits, implemented for three years up to 2016, the new four-year Benefit freeze impacts most where these benefits are claimed by the largest number of people.

This means that places with high numbers out-of-work on benefits or with large numbers claiming Housing Benefit or in-work benefits are again the ones hit hardest.

In practice, the benefit freeze reinforces the local and regional impact of several other welfare reforms.

Some of Britain's older industrial areas, a number of seaside towns and less affluent London boroughs face the greatest impacts.

Once more, it is large parts of southern and eastern England outside London that can expect to escape with the smallest financial losses. 


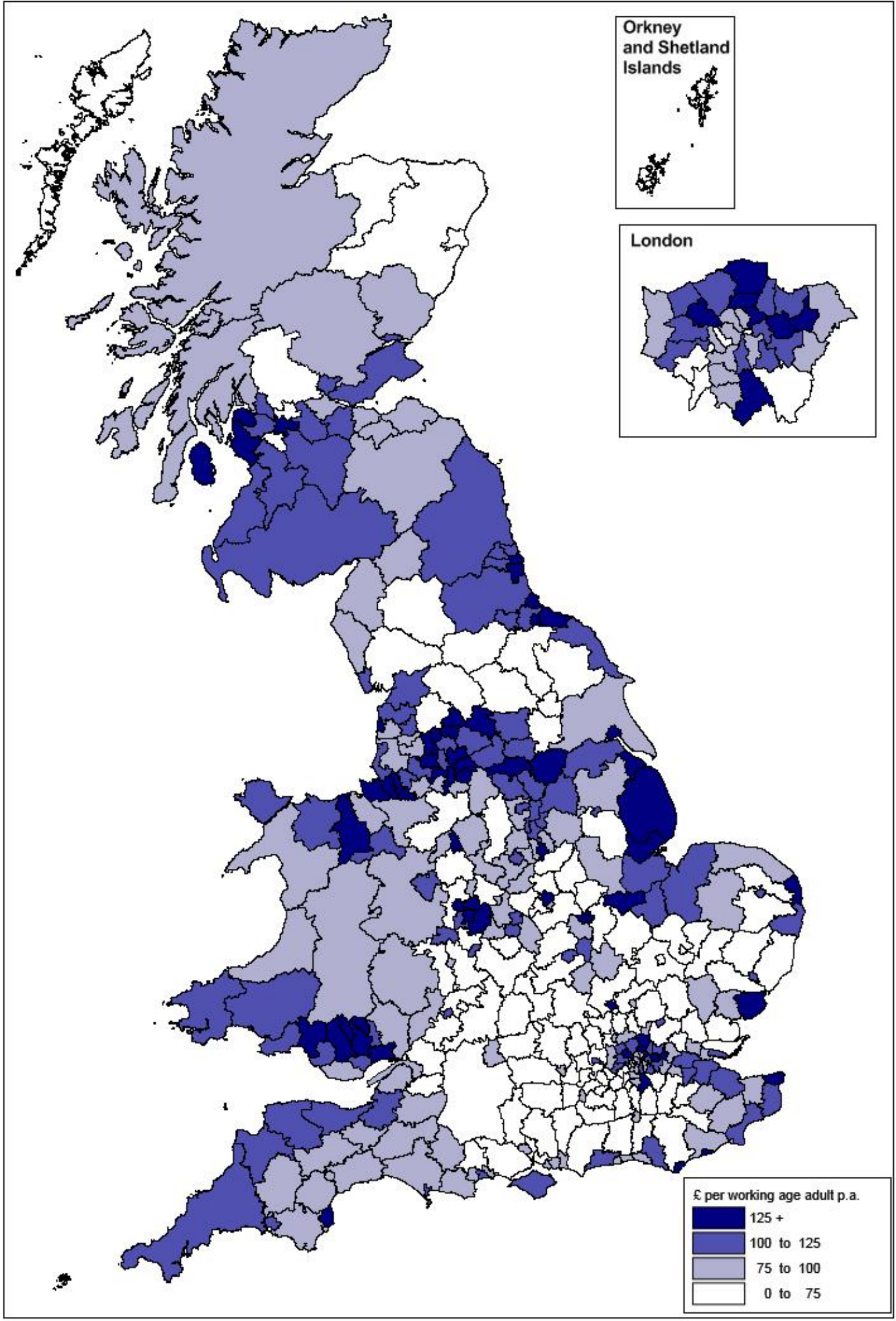

Source: Sheffield Hallam estimates based on official data 


\section{Reforms announced prior to May 2015}

\section{HOUSING BENEFIT: LOCAL HOUSING ALLOWANCE}

Rules governing assistance with the cost of housing for low-income households in the private rented sector

\section{Nature of reforms}

- Maximum rents set at $30^{\text {th }}$ percentile of local rents, rather than $50^{\text {th }}$ percentile, from 2011-12

- Caps on maximum rents for each property size, with 4-bed limit, from 2011-12

- Abolition of $£ 15$ excess formerly retained by tenants paying below maximum LHA rent, from 201112

- Increase age limit for shared room rate from 25 to 35, from January 2012

- Switch from $30^{\text {th }}$ percentile rents to CPI indexation for LHA, from 2013-14

\section{Total estimated loss}

$£ 1,645 \mathrm{~m}$ a year by $2014-15$

(Source: HM Treasury)

\section{Methods and data sources}

- Total loss arising from $30^{\text {th }}$ percentile, size caps and $£ 15$ excess $(£ 1040 \mathrm{~m}$ pa) allocated to local authorities on the basis of DWP estimates of the number of households affected and the average final loss (Source: DWP Impacts of Housing Benefit proposals: changes to LHA to be introduced in 2011-12)

- Loss arising from increase in age limit for shared room rate $(£ 215 \mathrm{~m} \mathrm{pa})$ allocated to local authorities on the basis of estimates of the numbers losing and average loss per week in each authority (Source: DWP Housing Benefit equality impact assessment: increasing the shared accommodation rate age threshold to 35)

- Loss arising from CPI indexation ( $£ 390 \mathrm{~m}$ pa) allocated to local authorities on the basis of the number of Housing Benefit claims in the private rented sector in each authority in August 2012 (Source: DWP)

- Number of affected households is the number of Housing Benefit claimants within the LHA system in each authority in May 2014 (Source: DWP). NB All LHA recipients affected by shift to CPI indexation.

\section{HOUSING BENEFIT: ‘BEDROOM TAX’}

New rules governing the size of properties for which payments are made to working age claimants in the social rented sector (council and housing association)

\section{Nature of the reform}

- Limit Housing Benefit payments to working-age households in social rented accommodation to a level reflecting the number of bedrooms justified by the size and age composition of the household, from 2013-14 


\section{Total estimated loss}

$£ 360 \mathrm{~m}$ a year by $2014-15$, revised down from initial HM Treasury estimate of $£ 490 \mathrm{~m}$ a year to reflect lower number of households affected than originally anticipated and the outturn financial losses per household

\section{Methods and data sources}

- Number of households affected in each local authority in June 2013 (Source: DWP). No households are affected In Scotland because the impact has been fully offset by Discretionary Housing Payments.

- Financial loss in each local authority based on number of affected households and the average financial loss per claimant in each authority in June 2013 (Source: DWP)

\section{NON-DEPENDANT DEDUCTIONS}

Deductions from Housing Benefit, Council Tax Benefit and other income-based benefits to reflect the contribution that non-dependant household members are expected to make towards the household's housing costs.

\section{Nature of reform}

- Up-rating the deductions in stages between April 2011 and April 2014 to reflect growth in rents and increases in Council Tax since 2001, when the deductions were frozen, and subsequent link to prices

\section{Total estimated loss}

$£ 210 \mathrm{~m}$ a year by $2014-15$, revised down from initial estimate of $£ 340 \mathrm{~m}$ a year (Source: HM Treasury)

\section{Methods and data sources}

- Estimated 300,000 claimants affected (Source: DWP Equality Impact Assessment: incomerelated benefits: changes to the non-dependent deduction rates) allocated on the basis of the number of Housing Benefit and Council Tax Benefit claimants in each local authority in August 2012 (Source: DWP).

- Financial loss allocated to local authorities on the basis of the estimated numbers affected (see above)

\section{BENEFIT CAP}

Ceiling on total payments to out-of-work households applying to sum of wide range of working age benefits

\section{Nature of reforms}

- Total household benefit payments for working-age claimants capped so that workless households receive no more in benefit than the average weekly wage, after tax and national insurance, from 2013-14, administered through Housing Benefit payments 


\section{Total estimated loss}

$£ 100 \mathrm{~m}$ a year by 2014-15, revised down from initial HM Treasury estimate of $£ 270 \mathrm{~m}$ a year, and later estimate of $£ 185 \mathrm{~m}$ a year, to reflect lower than anticipated number of affected households and outturn financial losses

\section{Methods and data sources}

- Number of households affected in each authority is the average between November 2013 and April 2014 (Source: DWP)

- Average financial loss per household in each authority in April 2014 (Source: DWP)

\section{COUNCIL TAX SUPPORT}

Paid to households on low incomes to offset Council Tax bills, in whole or in part

\section{Nature of the reform}

- 10 per cent reduction in expenditure by HM Treasury compared to previous scheme (Council Tax Benefit) and transfer of responsibility to local authorities, from 2013-14.

- Reduction in entitlement only permitted for working-age households; entitlement of pensioner households fully protected.

- Some local authorities in England have chosen not to pass on the reduction to claimants, in whole or in part, absorbing the cut within their budget. In Scotland and Wales the devolved administrations have made arrangements that avoid the reduction falling on claimants.

\section{Total estimated loss}

$£ 370 \mathrm{~m}$ a year in 2015-16, which is the reduction being passed on to claimants from HM Treasury's estimated saving of $£ 490 \mathrm{~m}$ a year in $2014-15$

\section{Methods and data sources}

- Number of households affected and average weekly loss, by authority, from statistics for 2015-16 published by the New Policy Institute. The NPI figures are based on information assembled from each local authority.

- The NPI data shows that some local authorities in England have chosen not to pass on the benefit reduction to claimants, in whole or in part, absorbing the cut elsewhere within their budget. In Scotland and Wales the devolved administrations have not passed on the cut to local authorities, thereby avoiding any impact on claimants.

\section{PERSONAL INDEPENDENCE PAYMENTS}

Payments intended to help offset the additional financial costs faced by individuals of all ages with disabilities, including those both in and out of work

\section{Nature of reform}

- Phased replacement of Disability Living Allowance (DLA) for working-age claimants by Personal Independence Payments (PIP), from 2013-14

- Introduction of more stringent medical test and regular re-testing

- Reduction in number of payment categories 


\section{Total estimated loss}

$£ 2,870 \mathrm{~m}$ a year by $2017-18$

(Source: HM Treasury revised estimate, Budget 2013)

\section{Methods and data sources}

- DWP anticipate a reduction in the national caseload of working age of 600,000 (see National Audit Office (2014) Personal Independence Payment: early progress, NAO, London), up from an original DWP estimate of 450,000. Additionally, 510,000 claimants in receipt of PIP instead of DLA are anticipated to experience a reduction in payment.

- Numbers allocated on the basis of stock of working age DLA claimants in each local authority in February 2012 (Source: DWP).

- Financial loss allocated to each local authority on basis of reduction in claimant numbers

- Financial losses by 2015-16 and from 2016-17 onwards from HM Treasury (Budget 2013)

\section{EMPLOYMENT AND SUPPORT ALLOWANCE}

Out-of-work payments to men and women of working age with health problems or disabilities, (including predecessors Incapacity Benefit, Income Support on grounds of disability, and Severe Disablement Allowance)

\section{Nature of reforms}

- Introduction of Employment and Support Allowance (ESA) for new claimants and a new, tougher medical test (the Work Capability Assessment), from October 2008

- Applying the Work Capability Assessment to existing incapacity claimants from autumn 2010 onwards, and migration to ESA if not deemed 'fit for work'

- Time-limiting to 12 months non-means tested entitlement for ESA Work Related Activity Group, from 2012-13

- New conditionality for ESA Work Related Activity Group

\section{Total estimated loss}

$£ 650 \mathrm{~m}$ a year by $2015-16$ comprising:

- $£ 440 \mathrm{~m}$ a year from time limiting of non-means tested entitlement, revised down from HM Treasury initial estimate of $£ 2,475 \mathrm{~m}$ a year by 2014-15 (Spending Review 2010) and subsequent estimate of $£ 1,475 \mathrm{~m}$ a year by 2015-16 (Budget 2012) to reflect lower numbers in the Work Related Activity Group

- $£ 210 \mathrm{~m}$ a year from reduction in ESA caseload

\section{Methods and data sources}

- Estimated number affected by time-limiting $(210,000)$ based on the difference in the proportion of ESA claimants in the WRAG group in receipt of contributory benefits in the four quarters to February 2012, just prior to the introduction of time-limiting. and in the four quarters to May 2015 (Source: DWP)

- Net reduction in ESA caseload based on difference between the average IB/SDA caseload in the four quarters to August 2008, just prior to the introduction of ESA for new claimants, and the average combined ESA and residual IB/SDA caseload in the four quarters to May 2015.

- Numbers affected by time-limiting allocated in proportion to the WRAG caseload in each local authority in May 2015 
- Reduction in the total caseload arising from the introduction of ESA allocated in proportion to the IB/ESA caseload in August 2008 (Source: DWP)

- Financial loss per affected claimant (£2,100 a year) based on DWP estimate of average financial loss arising from time-limiting (Source: DWP Impact Assessment: Time limit contributory Employment and Support Allowance to one year for those in the Work-Related Activity Group). There are no DWP estimates for the average financial loss for those removed from the ESA caseload but as some of these claimants will receive other means-tested benefits the magnitude of the financial losses are likely to be broadly similar.

\section{CHILD BENEFIT}

Paid to households on the basis of the number of children up to age 16 or, if they remain at school or in further education, up to 19

\section{Nature of reforms}

- Freeze benefit rates for three years from 2011-12, instead of up-rate with inflation

- Withdrawal of benefit from households including a higher earner (threshold at $£ 50,000$ and taper to $£ 60,000)$, from January 2013

\section{Total estimated loss}

$£ 3,025 \mathrm{~m}$ a year by $2014-15$, revised up from initial estimate of $£ 2,845 \mathrm{~m}$ a year (Source: HM Treasury)

\section{Methods and data sources}

- Numbers of families in receipt of Child Benefit, by local authority in August 2011, from HMRC (Source: HMRC Child Benefit Statistics: geographical analysis). NB All recipients affected by freeze.

- Financial loss arising from freeze allocated on basis of number of families in receipt of Child Benefit in each local authority (see above)

- Financial loss arising from withdrawal of benefit from high earners allocated on basis of number of families in receipt of Child Benefit multiplied by an index of median earnings in the three years 2010, 2011 and 2012 of residents in each local authority relative to the UK average (Source: Annual Survey of Hours and Earnings). County averages used where earnings data for districts is unavailable.

\section{TAX CREDITS}

Payments through the tax system of Child Tax Credit (CTC) and Working Tax Credit (WTC) to lower and middle income households

\section{Nature of reforms}

- Adjustments to thresholds, withdrawal rates, supplements, income disregards and backdating provisions, from 2011-12 onwards

- Changes in indexation and up-rating, from 2011-12 onwards

- Reductions in childcare element of WTC, from 2011-12

- Increase in working hours requirement for WTC, from 2012-13 


\section{Total estimated loss}

$£ 4,210$ m (net) a year by $2014-15$

(Source: HM Treasury)

\section{Methods and data sources}

- Overall loss allocated on the basis of the total number of families in receipt of CTC or WTC in December 2014, by local authority (Source: HMRC Child and Working Tax Credits Statistics: geographical analysis)

- All families in receipt of CTC or WTC affected by one or more of the changes

\section{PER CENT UP-RATING}

Annual up-rating of value of benefits

\section{Nature of reform}

- 1 per cent up-rating (instead of by CPI) for three years from 2013-14 for main working-age benefits, and for two years from 2014-15 for Child Benefit and for Local Housing Allowance within Housing Benefit

\section{Total estimated loss}

$£ 2,700 \mathrm{~m}$ a year by $2015-16$, revised down from HM Treasury estimate of $£ 3,430$ a year to reflect lower outturn level of inflation

\section{Methods and data sources}

- Total loss divided equally between DWP-administrated benefits and HMRC-administrated benefits (Child Benefit, CTC, WTC), reflecting split of overall expenditure on relevant benefits (Sources: DWP and HMRC)

- HMRC benefits loss allocated on basis of total number of families in receipt of CTC or WTC in December 2012, (Source: HMRC Child and Working Tax Credits: geographical analysis)

- DWP benefits loss divided 75:25 between working age benefits and Housing Benefit, reflecting split of overall expenditure on relevant benefits (Source: DWP)

- DWP working age benefits loss allocated on basis of out-of-work working age benefit numbers in February 2012, by local authority (Source: DWP)

- Housing Benefit loss allocated on basis of estimated expenditure on claimants in the private rented sector, by local authority, derived from overall Housing Benefit expenditure data for 2011/12 and share of claimants in the private rented sector in August 2012 (Sources: DWP)

- Estimated 30 per cent of all households affected (Source: DWP Welfare Reform and Work Bill: impact assessment of the benefit rate freeze). Allocated to local authorities in proportion to the sum of the numbers in receipt of Child Benefit in December 2014 and out-of-work working-age benefits in February 2012. 


\section{Reforms announced since May 2015}

\section{UNIVERSAL CREDIT TAPERS AND THRESHOLDS}

Benefit withdrawal as income of Universal Credit (UC) claimant rises

\section{Nature of reforms}

- Reduction in the level of earnings at which UC awards start to be withdrawn, from April 2016

- Increase in the rate at which UC awards are withdrawn from 41 per cent to 48 percent, from April 2016

\section{Total estimated loss}

$£ 3,220 \mathrm{~m}$ a year (net) by $2020-21$

(Sources: HM Treasury Summer Budget 2015 with revisions in Spending Review and Autumn Statement 2015)

\section{Methods and data sources}

- Overall loss allocated on the basis of the total number of families in work in receipt of CTC or WTC in December 2015, by local authority (Source: HMRC Child and Working Tax Credits Statistics: geographical analysis)

- All families in work in receipt of CTC or WTC affected by one or more of the changes

\section{TAX CREDITS (new reforms)}

Payments through the tax system to lower and middle income households, initially as Child Tax Credit and Working Tax Credit and eventually Universal Credit

\section{Nature of reforms}

- Limiting of child element to two children for new births in tax credits and new UC claims, from April 2017 ( $£ 1,365 \mathrm{~m}$ a year by $2020-21)$

- Removal of family element in tax credits and UC, and the family premium in Housing Benefit, for new claims, from April 2017 ( $£ 675 \mathrm{~m}$ a year by 2020-21)

- Reduction in income rise disregard in tax credits, from April 2016 ( $£ 110 \mathrm{~m}$ a year by $2020-21)$

- Uprated minimum income floor in UC for self-employed from 2016-17 ( $£ 180 m$ a year by 2020-21)

- Revised UC delivery schedule ( $£ 215 \mathrm{~m}$ extra spending in 2020-21 but net saving in earlier years)

\section{Total estimated loss}

$£ 2,115 \mathrm{~m}$ a year (net) by 2020-21

(Sources: HM Treasury Summer Budget 2015 and Spending Review and Autumn Statement 2015)

\section{Methods and data sources}

- Estimated numbers of households affected by child element $(640,000)$ from DWP Impact Assessment: Tax Credits and Universal Credit, changes to Child Element and Family Element

- 30 per cent of other tax credit claimants in December 2015 (Source: HMRC) assumed to be affected by one or more of the other changes. Family element is expected to affect $1,180,000$ households (Source: DWP Impact Assessment above) but there is overlap with those affected by the child element. 
- 65 per cent of financial loss (more than two children element) allocated on basis of number of families in receipt of Child Tax Credit multiplied by an index of the share of households with three or more dependent children in each local authority relative to the GB average in 2011 (Source: Census of Population).

- 35 per cent of financial loss (remaining measures) allocated on basis of numbers in receipt of tax credits in December 2015 (Source: HMRC Child and Working Tax Credits: geographical analysis)

- Total numbers affected in each local authority allocated in proportion to financial losses

\section{MORTGAGE INTEREST SUPPORT}

Assistance with mortgage payments for out-of-work claimant

\section{Nature of the reform}

- Change from welfare payment to loan, from April 2016

\section{Total estimated loss}

$£ 255 \mathrm{~m}$ a year by $2020-21$

(Source: HM Treasury Summer Budget 2015)

\section{Methods and data sources}

- 170,000 households affected (Source: DWP Welfare Reform and Work Bill: impact assessment for converting support for mortgage interest from a benefit into a loan).

- Number of households affected and financial loss allocated to local authorities in proportion to working-age benefit claimant numbers in each authority in May 2015 (Source: DWP) multiplied by an index of the share of households in owner-occupied housing relative to the GB average in 2011 (Source: Census of Population)

\section{'PAY TO STAY'}

Rent levels for higher-income social housing tenants

\section{Nature of the reform}

- Social housing tenants in London with a household income of $£ 40,000$ a year or more, and $£ 30,000$ a year or more in the rest of England, to pay market rents from April 2017

- Mandatory for local authority tenants; discretionary for housing associations

\section{Total estimated loss}

$£ 240 \mathrm{~m}$ a year by $2020-21$

(Source: HM Treasury Summer Budget 2015)

\section{Methods and data sources}

- $\quad £ 240 \mathrm{~m}$ a year saving to Treasury (and equivalent loss to tenants) is wholly attributable to higher rents in local authority housing. If housing associations use their discretionary power to apply 'pay to stay' the financial losses will be higher. 
- Financial loss allocated in proportion to the stock of local authority housing in each authority in 2014 (Source: CLG) multiplied by an index of the average value of Housing Benefit awards across four household types in the private rented sector in each authority relative to the England average in August 2015 (Source: DWP), and reduced by 25 per cent in London to reflect higher income threshold

- 200,000 households in local authority housing anticipated to be affected in 2017-18 (Source: CLG Housing and Planning Bill 2015/16: impact assessment). Reduced to 130,000 households in 2020-21 in proportion to the anticipated reduction in the financial saving to the Treasury between 2017-18 and 2020-21 as behavioural change (right to buy, choice of tenure) takes effect (Source: Summer Budget 2015)

- Affected households allocated in proportion to the financial losses multiplied by the reciprocal of the index above to reflect higher average losses in areas with high private sector rents.

- Scotland and Wales are unaffected by this reform

\section{LHA CAP IN SOCIAL RENTED SECTOR}

Support with housing costs for social sector tenants

\section{Nature of the reform}

- Housing Benefit in the social sector limited to the equivalent private sector rate, from April 2018

\section{Total estimated loss}

$£ 225 \mathrm{~m}$ a year by $2020-21$

(Source: HM Treasury Spending Review and Autumn Statement 2015)

\section{Methods and data sources}

- Financial loss arising from LHA cap allocated in proportion to number of households in social housing claiming Housing Benefit in each local authority in August 2015 multiplied by the ratio between the value of the average Housing Benefit claims in the social and private rented sectors in August 2015 (Sources: DWP)

- In absence of published government estimates, the number of households affected assumed to be 300,000 (given the Treasury's anticipated financial saving, this equates to an average loss of $£ 15$ per week per household). Numbers allocated in proportion to the financial losses.

\section{HOUSING BENEIT: 18-21 YEAR OLDS}

Support with housing costs for young people

\section{Nature of the reform}

- End of automatic Housing Benefit entitlement for out-of-work 18-21 year olds, from April 2017

\section{Total estimated loss}

$£ 40 \mathrm{~m}$ a year by 2020-21

(Source: HM Treasury Summer Budget 2015) 


\section{Methods and data sources}

- In absence of government estimates, but in line with anticipated financial saving, numbers affected assumed to be 15,000 , equating to an average loss of roughly $£ 50$ a week

- Number and financial losses allocated in proportion to the out-of-work claimant rate among under25s in each local authority in May 2015 (Source: DWP)

Because of the small scale of the overall financial loss, the figures for this reform are not mapped separately in Appendix1 but are included in the aggregate figures.

\section{EMPLOYMENT AND SUPPORT ALLOWANCE (new reforms)}

Out-of-work payments to men and women of working age with health problems or disabilities

\section{Nature of the reform}

- ESA in Work-Related Activity Group reduced to JSA rate for new claims

\section{Total estimated loss}

$£ 640 \mathrm{~m}$ a year by $2020-21$

(Source: HM Treasury Summer Budget 2015)

\section{Methods and data sources}

- Numbers affected $(500,000)$ from DWP Impact Assessment: remove the ESA Work-Related Activity Component and the UC Limited Capability for Work Element for new claims

- Numbers affected and financial losses allocated in proportion to the numbers claiming ESA in the WRAG group in each local authority in May 2015 (Source: DWP)

\section{BENEFIT CAP (extension)}

Ceiling on total payments to out-of-work households applying to sum of wide range of working age benefits

\section{Nature of reform}

- New, lower ceiling set at $£ 23,000$ a year in London and £20,000 elsewhere, from 2016-17

\section{Total estimated loss}

$£ 495 \mathrm{~m}$ a year by $2020-21$

(Source: HM Treasury Summer Budget 2015)

\section{Methods and data sources}

- Households already capped in London $(10,000)$ and in the rest of Britain $(13,000)$ lose $£ 3,000$ a year and $£ 6,000$ a year respectively. Numbers are averages for March-August 2015 (Source DWP). Households already capped therefore lose $£ 108 \mathrm{~m}$ a year.

- Remaining financial loss to newly capped households ( $£ 387 \mathrm{~m}$ a year) expected to average $£ 39$ per week, or £2,000 a year. (Source: DWP Welfare Reform and Work Bill: impact assessment for the benefit cap). This equates to 190,000 newly-capped households. 
- 24 per cent of all households affected by the new cap $(210,000)$ expected to be in London and 76 per cent elsewhere (Source: DWP Welfare Reform and Work Bill: impact assessment for the benefit cap). Implies 40,000 newly-capped households in London and 150,000 elsewhere.

- Financial loss to newly-capped households in London limited to $£ 3,000$ a year and assumed to be an average of $£ 1,300$ a year ( $£ 52 \mathrm{~m}$ in total)

- Loss of remaining $£ 335 \mathrm{~m}$ a year to 150,000 newly capped households outside London therefore estimated to average $£ 2,230$ a year

- Number of newly capped households affected in London and in the rest of GB allocated to each local authority: one-third in proportion to number on out-of-work benefits in May 2015 (Source: DWP); one-third in proportion to the ratio between the local share of households with 3 or more children and the GB average in 2011 (Source: Census of Population); and one-third in proportion to the ratio between the local value of Housing Benefit awards and the GB average in August 2015 (Source: DWP)

\section{BENEFIT FREEZE}

Below-inflation uprating of benefits

\section{Nature of reform}

- Freeze in value of most working-age benefits for four years from 2016-17

\section{Total estimated loss}

$£ 4,010 \mathrm{~m}$ a year by $2020-21$

(Source: HM Treasury Summer Budget 2015)

\section{Methods and data sources}

- Total loss divided 40:60 between DWP-administrated benefits and HMRC-administrated benefits (Child Benefit, CTC, WTC), reflecting the current split of overall expenditure on relevant benefits (Sources: DWP and HMRC)

- HMRC benefits loss allocated on basis of total number of families in receipt of CTC or WTC in December 2015, (Source: HMRC Child and Working Tax Credits: geographical analysis)

- DWP benefits loss divided 70:30 between working age benefits and Housing Benefit, reflecting the current split of overall expenditure on relevant benefits (Source: DWP)

- DWP working age benefits loss allocated on basis of out-of-work working age benefit numbers in May 2015, by local authority (Source: DWP)

- Housing Benefit loss allocated on basis of number claimants and average award in the private rented sector, by local authority (Source: DWP)

- Estimated 30 per cent of all households affected (Source: DWP Welfare Reform and Work Bill: impact assessment of the benefit rate freeze). Allocated to local authorities in proportion to the sum of the numbers in receipt of Child Benefit in December 2015 (Source: HMRC) and out-ofwork working-age benefits in May 2015 (Source: DWP). 


\section{Allocation of post-March 2016 financial loss by household type}

Personal Independence Payment (post-March 2016 impact of pre-2015 reform)

- Allocated in proportion to the number of households of each type claiming PIP predecessor Disability Living Allowance (Source: Family Resources Survey, with adjustments to match FRS data for 'benefit units' to Census data for 'household types' and to allow for the possibility that more than one individual in the same household is affected)

\section{Universal Credit tapers and thresholds}

- Allocated in proportion to the number of households of each type claiming Tax Credits (Source: Family Resources Survey, with adjustments as above). UC tapers and thresholds apply to households that would previously have claimed Tax Credits.

Tax Credits (new reforms)

- Child element allocated in proportion to numbers of households with two or more dependent children. Impact on non-couples reduced by 50 per cent and re-allocated proportionally to couples.

- Family element allocated in proportion to numbers of households with dependent children

- Remainder allocated in proportion to numbers of households in receipt of Tax Credits (Source: Family Resources Survey, with adjustments as above)

\section{Mortgage Interest Support}

- 45 per cent of households affected are of pension age (Source: DWP Welfare Reform and Work Bill: impact assessment for converting support for mortgage interest from a benefit into a loan). Allocated in proportion to numbers of pension-age households.

- 50 per cent of households affected have dependent children (Source: DWP Welfare Reform and Work Bill: impact assessment for converting support for mortgage interest from a benefit into a loan). Allocated in proportion to numbers of households with dependent children.

- Remaining 5 per cent allocated in proportion to numbers in other household types, excluding students

- Financial loss allocated in proportion to estimated number of households affected

'Pay to stay'

- Households above pension age and student households assumed to be unaffected

- Nominal 4,000 allocated to each of: lone parents with one dependent child, lone parents with two or more dependent children, and single-person working age households. These are household types with few likely to be above the income threshold.

- Remaining affected households allocated into three broad groups in proportion to social housing profile (Source: English Housing Survey 2013-14), then further divided in each group in proportion to the numbers of households of each type across GB

- Financial loss allocated in proportion to estimated number of households affected 


\section{LHA cap in social rented sector}

- Number of affected households allocated in proportion to social housing profile, using England as a guide to GB (Source: English Housing Survey 2013-14), then further divided in each group in proportion to the numbers of households of each type across GB. This assumes all household types in social housing (except pensioners - see below) are equally affected because LHA rates reflect household type. Student households assumed to be unaffected.

- Number of affected pensioner households reduced by 50 per cent to reflect higher incidence of exempt sheltered housing and lower rate of new tenancies, and reallocated proportionally to other household types.

- Financial loss allocated in proportion to estimated number of households affected

Housing Benefit: $18-21$ year olds

- Number of affected households assumed to be split equally between 'single working age' and 'other'

- Financial loss allocated in proportion to estimated number of households affected

\section{Employment and Support Allowance (new reforms)}

- Allocated in proportion to the number of households of each type claiming ESA or its predecessor incapacity benefits (Source: Family Resources Survey, with adjustments as above).

\section{Benefit Cap (extension)}

- 59 per cent of households affected are expected to be female lone parents (Source: DWP Welfare Reform and Work Bill: impact assessment for the benefit cap). Adding male lone parents, 66 per cent of all affected households are assumed to be lone parents.

- 60 per cent of lone parents affected are assumed to have two or more dependent children. The Benefit Cap is more likely to apply to larger families with higher entitlement.

- 5 per cent of households affected assumed not have dependent children. Allocated in proportion to stock of households without dependent children (excluding pensioners and students).

- Remaining affected households split 60/40 between households with two or more dependent children and households with one, and allocated in proportion to number of each type

- Financial loss allocated in proportion to estimated number of households affected

\section{Benefit freeze}

- Allocated in proportion to the number of households of each type claiming relevant benefits (Source: Family Resources Survey, with adjustments as above). 


\section{Allocation of post-March 2016 financial loss by housing tenure}

- Losses arising from PIP and ESA allocated to each tenure on the basis of number of households claiming PIP/DLA and ESA/IB (Source: Family Resources Survey)

- Losses arising from UC tapers and thresholds and from Tax Credit changes allocated to each tenure on the basis of number of households claiming Tax Credits (Source: Family Resources Survey)

- Loss arising from benefit freeze allocated to each tenure on the basis of number of households claiming income-related benefits (minus Pension Credit) (Source: Family Resources Survey)

- Loss arising from Benefit Cap extension allocated 54/46 between the social rented and private rented sectors on the basis of the number of households in each sector affected by the pre-2015 cap in November 2015 (Source: DWP)

- Loss from 'pay to stay' and new LHA cap in social rented sector confined to social housing

- Loss from mortgage interest support confined to owner-occupied sector

- Loss from new Housing Benefit rules for 18-21 year olds split evenly between the social and private rented sectors, guided by data on single unemployed 18-21 year olds with no dependent children claiming Housing Benefit (Source: DWP)

- 100 per cent of the loss from PIP, UC tapers and thresholds, 18-21s and ESA, 35 per cent of the loss from Tax Credits, 60 per cent of the loss from the Benefit Cap and 75 per cent of the loss from the benefit freeze allocated to the social rented sector (SRS) in each local authority by the formula:

Local loss (£m) multiplied by national share of loss from each reform in SRS multiplied by (local share of households in SRS divided by GB share of households in SRS)

(Source: 2011 Census of Population)

- To take account of the impact on low-income large families and local variation in their distribution by tenure, 65 per cent of the loss from Tax Credits, 40 per cent of the loss from the Benefit Cap and 25 per cent of the loss from the benefit freeze allocated to the SRS in each authority by the formula:

Local loss (£m) multiplied by local share of households with 3 or more dependent children living in SRS and claiming Housing Benefit

(Sources: 2011 Census of Population and DWP)

- Loss by local authority from 'pay to stay' and LHA cap in social rented sector added to loss In SRS (see earlier)

- Total number of households and number of working-age households, by sector for GB and each local authority, from 2011 Census of Population 



CRESR
Sheffield Hallam University
City Campus
Sheffield S1 1WB
+44 (0)114 2253073
e: cresr@shu.ac.uk
w: shu.ac.uk/cresr
ISBN: 978-1-84387-392-1
neffield | Centre for
allam
niversity




\section{Sheffield Hallam University}

The uneven impact of welfare reform : the financial losses to places and people

BEATTY, Christina <http://orcid.org/0000-0003-0943-9979> and FOTHERGILL, Stephen $<$ http://orcid.org/0000-0002-4201-0640>

Available from the Sheffield Hallam University Research Archive (SHURA) at:

http://shura.shu.ac.uk/15883/

\section{Copyright and re-use policy}

Please visit http://shura.shu.ac.uk/15883/ and http://shura.shu.ac.uk/information.html for further details about copyright and re-use permissions. 